Luciano Matsumiya Thomazelli

\title{
VIGILÂNCIA EPIDEMIOLÓGICA DO VÍRUS DA DOENÇA DE NEWCASTLE EM AVES DOMÉSTICAS E SELVAGENS PELO MÉTODO DE REAL TIME PCR
}

Tese (Doutorado) apresentada ao Programa de Pós-Graduação Interunidades em Biotecnologia USP/Instituto Butantan/IPT, para obtenção do Título de Doutor em Biotecnologia. 
Luciano Matsumiya Thomazelli

\section{VIGILÂNCIA EPIDEMIOLÓGICA DO VÍRUS DA DOENÇA DE NEWCASTLE EM AVES DOMÉSTICAS E SELVAGENS PELO MÉTODO DE REAL TIME PCR}

Tese (Doutorado) apresentada ao Programa de Pós-Graduação Interunidades em Biotecnologia USP/Instituto Butantan/IPT, para obtenção do Título de Doutor em Biotecnologia.

Área de concentração:

Microbiologia

Orientador:

Prof. Dr. Edison Luiz Durigon

São Paulo

2009 
A todos os meus familiares (mãe Terumi, memória de meu pai Rubens, irmãos Daniel e Beliza, e sobrinha Beatriz) e minha noiva Roberta Sakamoto, pelo incentivo, apoio e carinho.

Dedico 


\section{AGRADECIMENTOS}

Agradeço a todas as pessoas que direta ou indiretamente contribuíram para a execução deste trabalho, em especial,

Minha mãe Terumi Matsumiya Thomazelli, meu pai Rubens Thomazelli [in memoriam] e o restante da família que além da dedicatória têm minha eterna gratidão.

Ao prof. Edison L. Durigon que mais do que um orientador, se mostrou um grande amigo.

A todos os integrantes da equipe de campo do Laboratório de Virologia Clínica e Molecular do Instituto de Ciências Biomédicas da USP: Jansen de Araújo, Luiz Sanfilippo, Carolina Ferreira, Renata Hurtado, Tatiana Ometto, José Maria Lopes, Miguel Golono, Cristiane Demetrio, Mário Figueiredo e a equipe de suporte: Ricardo, Dani, Lílian e Juliana.

Aos amigos pesquisadores Adriano Carrasco, Adélia Kawamoto e Liana Brentano, por terem cedido conhecimentos e reagentes importantes ao trabalho.

À toda a família da Danielle BL de Oliveira (Dona la, Tita e Clícia, Seu Neca) que sempre nos receberam muito bem durante as expedições.

À Isaura e toda sua família (Dona Maróquinha, Ivaldo, Isaudo e etc...) que não só nos acolheram muito bem, como também tiveram de trabalhar bastante nas expedições.

Aos Ilmos. membros da minha banca examinadora de qualificação: Dr. José Antônio Jerez, Dr. César Augusto Dinola Pereira, Dra. Viviane Fongaro Botosso, Dra. Maria Luisa Barbosa, Dra. Silvana R. Favoretto Lazarini e Dra. Danielle Bruna Leal de Oliveira.

Todos os amigos do Laboratório de Virologia - USP: Andréa, Angélica, Ariane, César, Claudionor, Danila, Eduardo, Maria Paula, Cláudia, Dyana, Fábio, Felipe, Gustavo, Hildener, Jean, Larissas, Lilia, Patrícia, Thereza, "Frank", Raquel, Vivian...

Ao meu "orientador" Prof. Dr. Manoel Armando Azevedo dos Santos e sua funcionária Maria Jacinta, pelo apoio e amizade.

À FAPESP pelo apoio financeiro às expedições.

Ao Laércio, prefeito de São Sebastião de Boa Vista (Marajó PA) e todos os seus secretários, em especial ao "Pingo de Ouro" secretário da cultura, que nos receberam muito bem na segunda expedição, e souberam valorizar nossa pesquisa, divulgando-a e assumindo total responsabilidade por nosso bem estar.

Aos Profs. Severino Mendes Jr. e Joaquim O. Branco, e suas respectivas equipes, pela ajuda durante as Expedições Volantes. 
À marinha do Brasil e o programa PROANTAR pelo suporte à Expedição Antártica. Às secretárias (o) do Programa de Biotecnologia da USP, Eliane, Fábia e Marcos. Às funcionárias da Biblioteca do ICB, Maria José e Eva Aparecida.

Ao CNPq pelo suporte financeiro de todo o projeto, incluindo minha bolsa de doutorado!

E por fim, por tudo, à mulher da minha vida Roberta M. Sakamoto. 
"Trago dentro do meu coração,

Como num cofre que se não pode fechar de cheio,

Todos os lugares onde estive,

Todos os portos a que cheguei,

Todas as paisagens que vi através de janelas ou vigias,

Ou de tombadilhos, sonhando,

E tudo isso, que é tanto, é pouco para o que eu quero".

Álvaro de Campos 


\section{RESUMO}

Thomazelli LM. Vigilância epidemiológica do vírus da Doença de Newcastle em aves domésticas e selvagens pelo método de Real Time PCR [Tese]. São Paulo: Instituto de Ciências Biomédicas da Universidade de São Paulo; 2009.

A avicultura brasileira é atualmente uma atividade de grande sucesso. A utilização de sistemas de planejamento associados a novas tecnologias, reflete-se no extraordinário crescimento da atividade. A produção brasileira de frango ultrapassou a marca anual de 10 milhões de toneladas, em 2007. O Brasil está entre os três maiores produtores de frango no ranking mundial, junto com Estados Unidos e China. Haja vista a importância que a avicultura representa para o país, pela geração de benefícios sociais e econômicos, o risco que a Doença de Newcastle (DNC) constitui para a avicultura brasileira é enorme. Um surto desta doença em um centro de produção avícola representaria um risco à economia e incidiria de forma negativa nos níveis de consumo de proteína de qualidade e economicamente acessível à população. A fim de estabelecermos um monitoramento do vírus da Doença de Newcastle (NDV) em aves selvagens, livres ou de cativeiro, e aves domésticas não vacinadas, residentes em regiões de elevada confluência migratória aviária no Brasil e em pingüins ao redor da Estação Antártica Comandante Ferraz (EACF), coletamos amostras de swabs orais e cloacais para a posterior análise por PCR em Tempo Real (qPCR), além de sangue para testes sorológicos, tendo como objetivos maiores, contribuir para o fortalecimento dos serviços de defesa sanitária animal, aumentar a capacidade de investigação, e finalmente, atualizar e harmonizar normas e procedimentos para a prevenção e controle da DNC, referenciando-se nas recomendações da Organização Mundial de Sanidade Animal (Office International des Epizooties - OIE). Das 1072 aves amostradas em diferentes regiões do Brasil, 8 $(0,75 \%)$ apresentaram resultado positivo para o NDV por qPCR, sendo 5 (62,5\% das positivas) delas provenientes da região Norte, 2 ( $25 \%$ das positivas) do Nordeste e 1 (12,5\% das positivas) da região Sul do Brasil. Na Antártica, dos 100 pingüins estudados, 2 apresentaram resultado positivo para o NDV por qPCR e em cerca de $33,3 \%$ dos soros testados foi detectada a presença de anticorpo pelo teste de Inibição da Hemaglutinação (HI). Todas as amostras positivas foram re-analisadas por qPCR específico para cepas mesogênicas e/ou velogênicas, resultando negatividade, corroborando os dados que certificam o Brasil como sendo livre da Doença de Newcastle.

Palavras-chave: Vírus da Doença de Newcastle. APMV-1. Vigilância Epidemiológica. 


\begin{abstract}
Thomazelli LM. Surveilance of Newcastle disease virus in domestics and wild birds by Real Time PCR [Thesis]. São Paulo: Instituto de Ciências Biomédicas da Universidade de São Paulo; 2009.

Brazilian chicken meat exports ended 2007 with shipments of 3,3 million tons, which represented a $21 \%$ increase in comparison with 2006 . These results were the best in the history of the poultry sector in Brazil. The production reached 10.2 million tons, a result that kept the country as the world's largest chicken meat exporter and the third largest producer, only behind USA and China. Thus the risk of an introduction of the Newcastle disease virus (NDV) into domestic poultry is enormous and will play severe consequences for the economy and poltry industries. In order to provide the surveillance of the NDV in wild, free or captive, and non vaccinated domestic birds from some regions of migratory birds confluence in Brazil and in penguins around the brasilian Antarctic Station Comandante Ferraz, we collected oral and cloacal swabs, for the viral detection by Real Time PCR (qPCR), and blood for the serological test (hemaglutination inhibition test - HI). A total of 1072 birds were sampled in diferent regions of Brazil, where $8(0.75 \%)$ shown positive results to NDV, in which $5(62.5 \%$ of positive) were from North region, 2 (25\% of positive) were from Northeast and 1 $(12,5 \%$ of positive) was from South. In the Antarctic 100 penguins were studied, in which 2 were detected the NDV ( $2 \%$ of total). HI test showed that $33.3 \%$ of penguins were seropositives for NDV, indicating their previous contact with the pathogen. All the positive samples by qPCR were repeated with primers projected to detect only virulent strains and no sample was positive, indicating the absence of velogenic strains in Brazil. The epidemiological profile was richer with the isolament of positive samples in embrioned chiken eggs specific patogen free and latter nucleotidic genomic sequencing of isolate.
\end{abstract}

Keywords: Newcastle disease virus. APMV-1. Surveilance. Real-time PCR. 


\section{SUMÁRIO}

1 INTRODUÇÃO __ 11

1.1 Panorama granjeiro brasileiro __ 11

1.2 Rotas migratórias aviárias___ 15

1.3 Doença de Newcastle _ـ 19

1.3.1 Histórico _ 19

1.3.2 Patologia _ 19

1.3.3 Classificação _ 21

1.3.4 Características estruturais e genéticas___ 22

1.3.5 Replicação _ 24

1.3.6 Epidemiologia___ 27

1.3.7 Diagnóstico__ 27

1.3.8 Prevenção__ 28

1.4 Histórico da DNC no Brasil __ 30

1.5 Antártica__ 31

1.6 Considerações finais __ 33

2 OBJETIVO _ 36

3 MATERIAL E MÉTODOS

3.1 Logística __ 37

3.2 Expedições Anuais _ـ 39

3.3 Expedições Volantes ___ 42

3.4 Expedição Antártica ___ 43

3.5 Armadilhamento _ 46

3.6 Triagem e identificação ___ 46

3.7 Coleta do material___ 47

3.8 Extração do RNA total ___ 48

3.9 Transcrição Reversa___ 49

3.10 Primers 49

3.11 Reação em Cadeia da Polimerase em Tempo Real (qPCR) __ 51

3.12 Isolamento ___ 52 
3.13 Hemaglutinação e Inibição da Hemaglutinação (HA e HI) 53

3.14 Índice de Patogenicidade: Tempo Médio de Morte de Embriões (TME) 53

3.15 Prevenção de contaminação e biossegurança 54

3.16 Otimização e teste das reações 54

3.17 Sequenciamento do material genético 55

3.18 Alinhamento e filogenia 56

4 RESULTADO 59

4.1 Padronização 59

4.2 Resultado das coletas 61

4.2.1 $q P C R$ 61

4.2.2 Isolamento e Sequenciamento 63

4.2.3 Sorologia 69

5 DISCUSSÃO 71

5.1 NDV no Brasil 71

5.2 NDV na Antártica 78

6 CONCLUSÃO 81 REFERÊNCIAS 83 


\section{INTRODUÇÃO}

\subsection{Panorama granjeiro brasileiro}

A avicultura brasileira é atualmente uma atividade de grande sucesso. Tem-se utilizado sistemas de planejamento associados a novas tecnologias,resultando em seu extraordinário crescimento. A produção brasileira de frango ultrapassou a marca anual de 10 milhões de toneladas, em 2007. O Brasil ocupa a terceira posição no ranking mundial dos maiores produtores de frango, sendo superado apenas por Estados Unidos e China, porém, considerando o item exportação, o Brasil lidera esse ranking desde 2004, sendo o maior exportador mundial de carne de frango (Associação brasileira dos exportadores de frango - ABEF, 2007) (Ilustração 1).

\section{Produção Mundial de Carne de Frango em 2007}

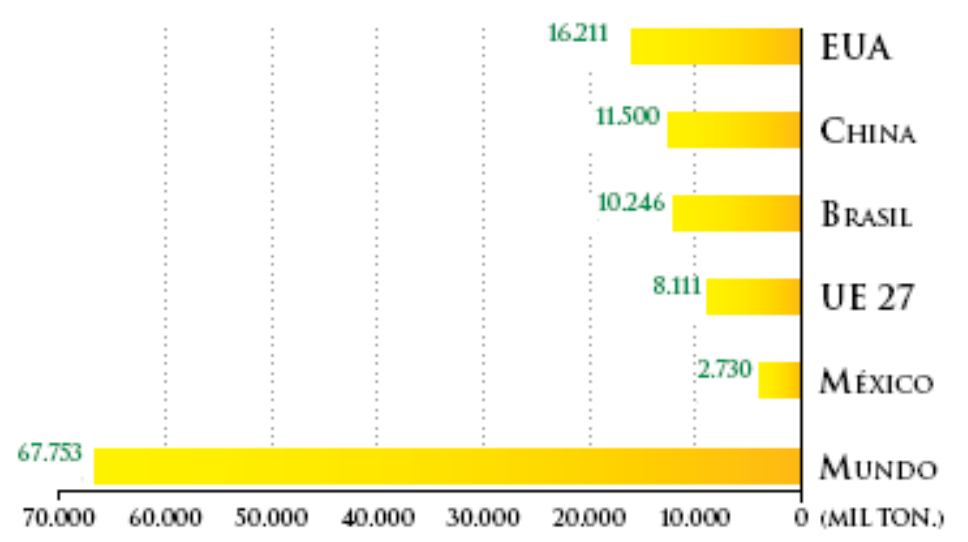

Exportação Mundial de Carne de Frango em 2007

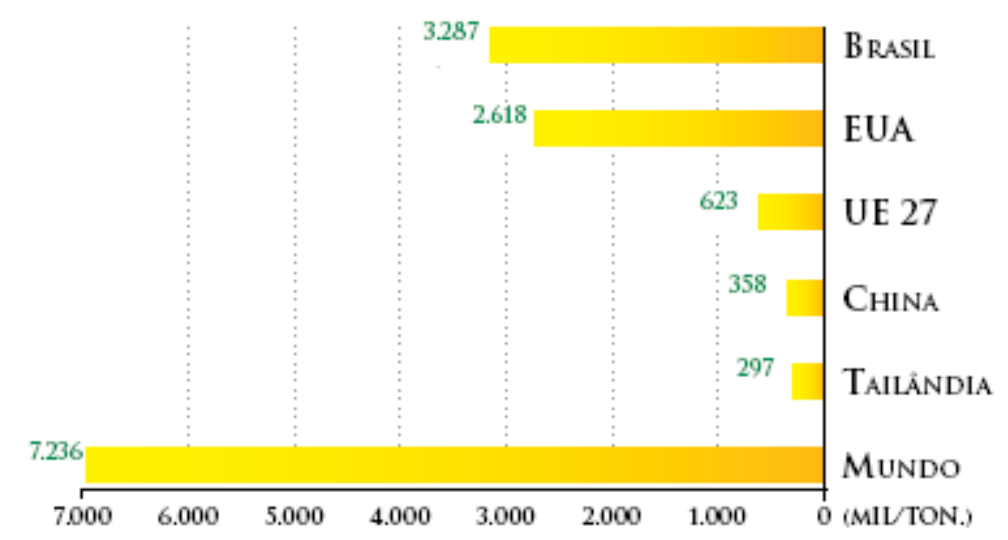

llustração 1- Gráfico da Produção/Exportação mundial de carne de frango em toneladas para o ano de 2007, dos maiores produtores/exportadores mundiais (ABEF, 2007). 
Segundo o Ministério da Agricultura, Pecuária e Abastecimento (MAPA,2007), as exportações do agronegócio em 2007 totalizaram US\$ 58,416 bilhões, um recorde histórico para o setor, que significou uma taxa de crescimento de 18,2\% em relação a 2006. O complexo soja continuou liderando o ranking de setores exportadores do agronegócio, porém, uma das maiores contribuições para a expansão das exportações foi dada pelo setor de carnes, principalmente carne de frango e de peru que tiveram taxas de crescimento de 44,2 e 48,5\%, respectivamente (Ilustração 2).

\begin{tabular}{|c|c|c|c|c|c|c|c|c|c|}
\hline & \multicolumn{3}{|c|}{ Valor (US\$ milhões) } & \multicolumn{3}{|c|}{ Quantidade (mil toneladas) } & \multicolumn{3}{|c|}{ Preço Médio (US\$/t) } \\
\hline & 2007 & 2006 & $\Delta \%$ & 2007 & 2006 & $\Delta \%$ & 2007 & 2006 & $\Delta \%$ \\
\hline \multicolumn{10}{|c|}{ EXPORTAÇŌES DO AGRONEGÓCIO } \\
\hline Complexo Soja & 11.381 & 9.308 & 22,3 & 38.541 & 39.703 & $-2,9$ & 295 & 234 & 26,0 \\
\hline Soja & 6.703 & 5.660 & 18,4 & 23.721 & 24.950 & $-4,9$ & 283 & 227 & 24,6 \\
\hline Farelo de soja & 2.959 & 2.420 & 22,3 & 12.477 & 12.334 & 1,2 & 237 & 196 & 20,9 \\
\hline Óleo de soja & 1.720 & 1.229 & 40,0 & 2.343 & 2.419 & $-3,2$ & 734 & 508 & 44,6 \\
\hline Carnes & 11.295 & 8.641 & 30,7 & 5.875 & 5.088 & 15,5 & 1.923 & 1.698 & 13,2 \\
\hline Carne de Frango & 4.620 & 3.203 & 44,2 & 3.162 & 2.713 & 16,6 & 1.461 & 1.181 & 23,7 \\
\hline in natura & 4.217 & 2.923 & 44,3 & 3.007 & 2.586 & 16,3 & 1.403 & 1.130 & 24,1 \\
\hline industrial izada & 402 & 281 & 43,2 & 155 & 127 & 22,1 & 2.589 & 2.207 & 17,3 \\
\hline Carne Bovina & 4425 & 3.923 & 12,8 & 1.615 & 1.523 & 6,0 & 2.740 & 2.576 & 6,4 \\
\hline in natura & 3.486 & 3.134 & 11,2 & 1.286 & 1.225 & 4,9 & 2.711 & 2.558 & 6,0 \\
\hline industrializada & 694 & 654 & 6,1 & 209 & 203 & 3,2 & 3.313 & 3.221 & 2,8 \\
\hline Carne Suina in natura & 1.162 & 990 & 17,4 & 552 & 484 & 14,0 & 2.105 & 2.045 & 3,0 \\
\hline Carne de Peru & 390 & 263 & 48,5 & 177 & 156 & 13,6 & 2.201 & 1.684 & 30,7 \\
\hline industrializada & 250 & 151 & 65,8 & 93 & 77 & 20,8 & 2.684 & 1.956 & 37,2 \\
\hline in natura & 140 & 112 & 25,2 & 84 & 79 & 6,6 & 1.667 & 1.419 & 17,4 \\
\hline Produtos Florestais & 8.819 & 7.881 & 11,9 & 14.963 & 14.728 & 1,6 & 589 & 535 & 10,2 \\
\hline Papel e Celulose & 4.726 & 4.005 & 18,0 & 8.590 & 8.235 & 4,3 & 550 & 486 & 13,1 \\
\hline Madeiras e suas obras & 4.091 & 3.875 & 5,6 & 6.372 & 6.493 & $-1,9$ & 642 & 597 & 7,6 \\
\hline Complexo Sucroalcoole iro & 6.578 & 7.772 & $-15,4$ & 22.183 & 21.603 & 2,7 & 297 & 360 & $-17,6$ \\
\hline Açúcar & 5.100 & 6.167 & $-17,3$ & 19.359 & 18.870 & 2,6 & 263 & 327 & $-19,4$ \\
\hline Alcool & 1478 & 1.605 & $-7,9$ & 2.824 & 2.733 & 3,3 & 523 & 587 & $-10,9$ \\
\hline Café & 3.891 & 3.364 & 15,7 & 1.574 & 1.557 & 1,1 & 2.472 & 2.161 & 14,4 \\
\hline Café em gráos & 3.405 & 2.953 & 15,3 & 1.494 & 1.481 & 0,9 & 2.279 & 1.994 & 14,3 \\
\hline Café solúvel & 451 & 383 & 17,7 & 71 & 68 & 5,4 & 6.311 & 5.648 & 11,7 \\
\hline Couros e seus produtos & 3.554 & 3.471 & 2,4 & 468 & 500 & $-6,5$ & 7.592 & 6.934 & 9,5 \\
\hline Sucos de frutas & 2.374 & 1.570 & 51,3 & 2.165 & 1.854 & 16,8 & 1.097 & 847 & 29,5 \\
\hline Fumoe seus produtos & 2.262 & 1.752 & 29,2 & 710 & 581 & 22,1 & 3.186 & 3.013 & 5,7 \\
\hline Milho & 1.882 & 460 & 309,1 & 10.915 & 3.925 & 178,1 & 172 & 117 & 47,1 \\
\hline Frutas frescas & 642 & 474 & 35,5 & 920 & 805 & 14,3 & 698 & 589 & 18,5 \\
\hline Algodáo & 507 & 338 & 49,9 & 419 & 305 & 37,7 & 1.209 & 1.111 & 8,8 \\
\hline Pescados & 311 & 368 & $-15,6$ & 58 & 77 & $-24,4$ & 5.335 & 4.776 & 11,7 \\
\hline Camaróes & 75 & 154 & $-51,6$ & 17 & 34 & $-49,3$ & 4.346 & 4.553 & $-4,5$ \\
\hline Lácteos & 299 & 169 & 77,6 & 104 & 99 & 4,9 & 2.888 & 1.706 & 69,3 \\
\hline Demais produtos & 4.619 & 3.858 & 19,7 & - & - & & - & - & \\
\hline IOTAL & 58.416 & 49.424 & 18.2 & - & - & & - & - & \\
\hline
\end{tabular}

Ilustração 2- Quadro dos principais produtos exportados no agronegócio brasileiro durante os anos de 2006 e 2007 (MAPA, 2007). 
Apesar de o Brasil ser um país de proporções continentais, mais de $70 \%$ de sua produção nacional de carne de frango concentra-se na região Sul, entre os Estados de Paraná, Santa Catarina e Rio Grande do Sul, que são os principais exportadores (Ilustração 3).

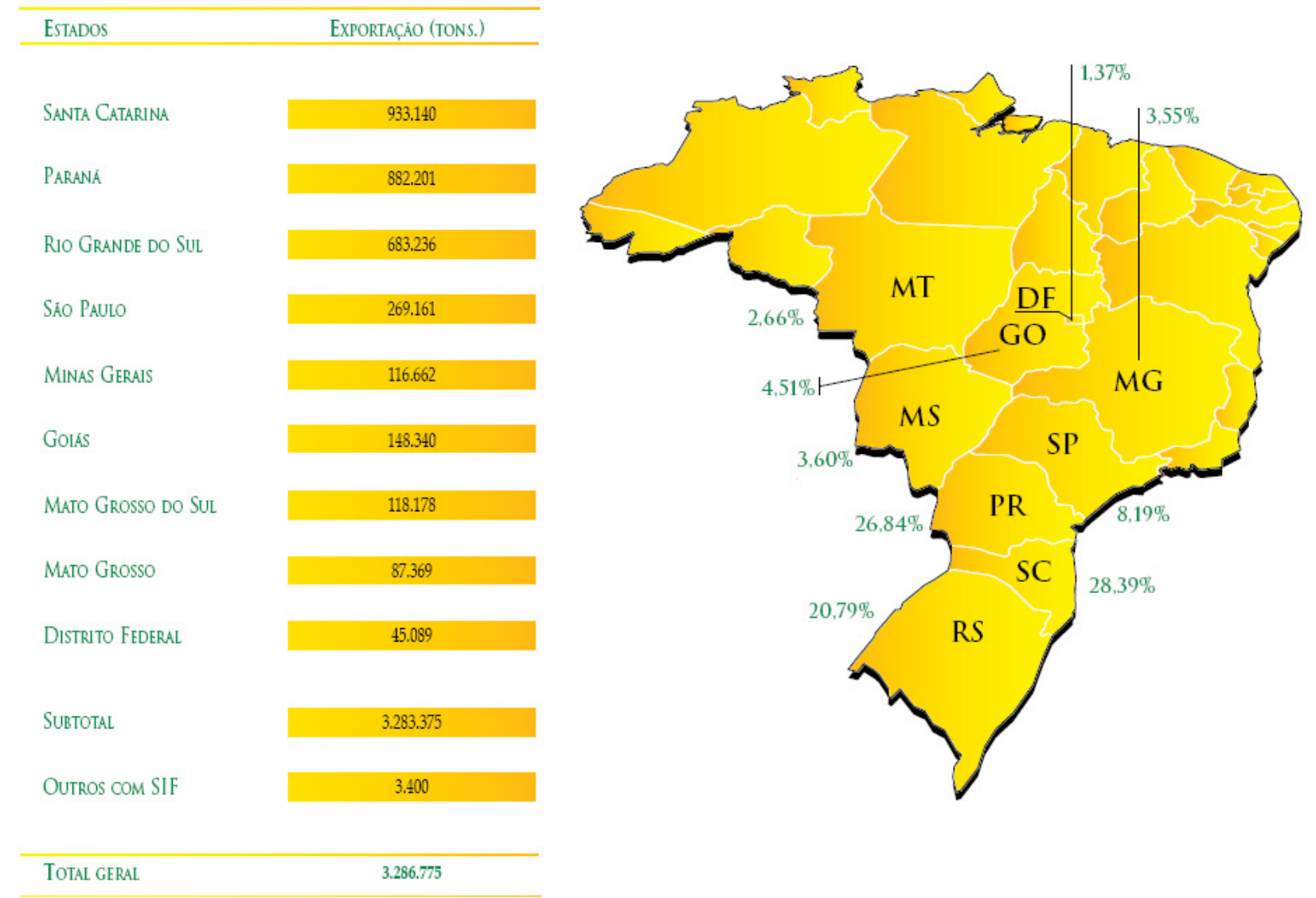

Ilustração 3- Localização dos maiores estados exportadores de carne de frango e suas respectivas contribuições em toneladas e em porcentagem para a exportação Brasileira de carne de frango em 2007 (ABEF, 2007).

A importância da carne de frango não se resume apenas na economia do país, mas também, em representar uma fonte de proteína de qualidade e economicamente acessível à população. As carnes brancas apresentam basicamente os mesmos nutrientes da carne vermelha: proteínas de alto valor nutritivo (ricas em aminoácidos indispensáveis), ferro hemínico, zinco, com a vantagem de normalmente apresentarem menor quantidade de gordura saturada $\mathrm{e}$ colesterol, e melhor digestibilidade, visto que é pobre em colágeno. Além disso, a 
carne de frango é considerada uma fonte importante de vitaminas do grupo B, principalmente B2 e B12 (Venturini, 2007).

Quase $70 \%$ da produção brasileira de carne de frango é destinada a abastecer o mercado interno. O consumo médio de carne de frango não para de crescer e até o ano de 2006 era de aproximadamente $35,68 \mathrm{Kg}$ por habitante por ano (Ilustração 4).

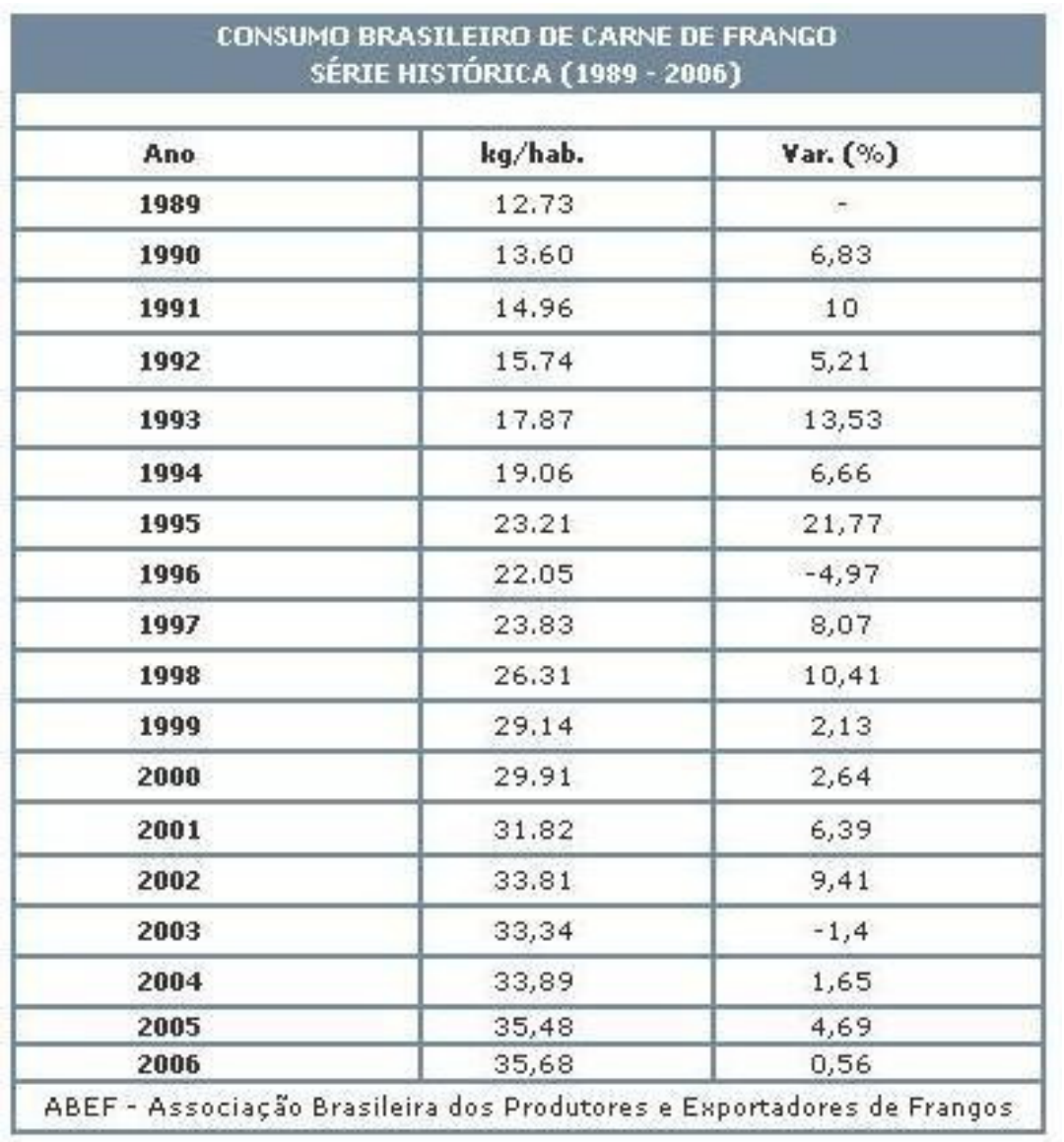

Ilustração 4- Série histórica do consumo brasileiro médio anual de carne de frango no período de 1989 a 2006 , em Kg por habitante (ABEF, 2006).

Devemos considerar, ainda, que para muitos brasileiros, sobretudo no Norte e Nordeste, assim como em outros países em desenvolvimento, os frangos de "fundo de quintal", ou frangos domésticos caipiras, representam uma fonte extremamente importante de alimento na forma de ovos e carne, e que o surgimento de uma doença como a de Newcastle, uma patologia altamente contagiosa que afeta aves domésticas e selvagens com grande potencial epidêmico e letal, sobretudo em aviários, poderia ter um impacto nas produções de frangos domésticos, tão grande quanto nas comerciais (Alexander, 2001). 


\subsection{Rotas migratórias aviárias}

O impacto econômico global da Doença de Newcastle (DNC) é enorme, acarretando diversos prejuízos aos países nos quais ela é endêmica. É considerada a principal doença do Plano Nacional de Sanidade Avícola (PNSA), uma vez que é grande a possibilidade de sua entrada, seja por meios naturais ou antrópicos, ao Brasil, um país considerado não endêmico.

Um dos meios naturais de introdução da DNC ao Brasil poderia ser pelo carreamento de cepas virulentas do vírus da Doença de Newcastle (NDV), agente causador da doença, por intermédio de aves migratórias existentes. O tamanho considerável da população de aves selvagens, a ausência de fronteiras e a liberdade de movimentos das aves migratórias, fazem com que essa população seja considerada um vetor extremamente importante de disseminação viral.

Ainda são poucos os dados para a realização de uma boa análise de risco da possível chegada da doença por intermédio das aves. De maneira geral, é muito restrito o conhecimento sobre as migrações de aves pelo interior do país e a biologia das espécies. O maior número de informações disponíveis é sobre algumas espécies de Charadriiformes em suas rotas migratórias na região costeira do país. Ainda não sabemos qual a suscetibilidade de cada uma dessas espécies migrantes de se tornar um potencial reservatório, condutor e transmissor do vírus. Para isso é fundamental um maior conhecimento sobre a epidemiologia do NDV em diferentes grupos de aves, informações sobre a ecologia e comportamento, além dos padrões migratórios das espécies.

As rotas migratórias aviárias são agrupadas e denominadas como "flyways" (llustração 5) para facilitar os esforços internacionais de manejo e conservação. Uma flyway pode ser definida como "a completa extensão na qual uma espécie migratória aviária (ou grupos, ou espécies relacionadas, ou populações distintas de uma mesma espécie) se locomove anualmente de uma área de reprodução para uma área de não-reprodução, incluindo lugares intermediários de descanso e alimentação, bem como áreas de ocorrência das mesmas” (Boere e Stroud, 2006). 


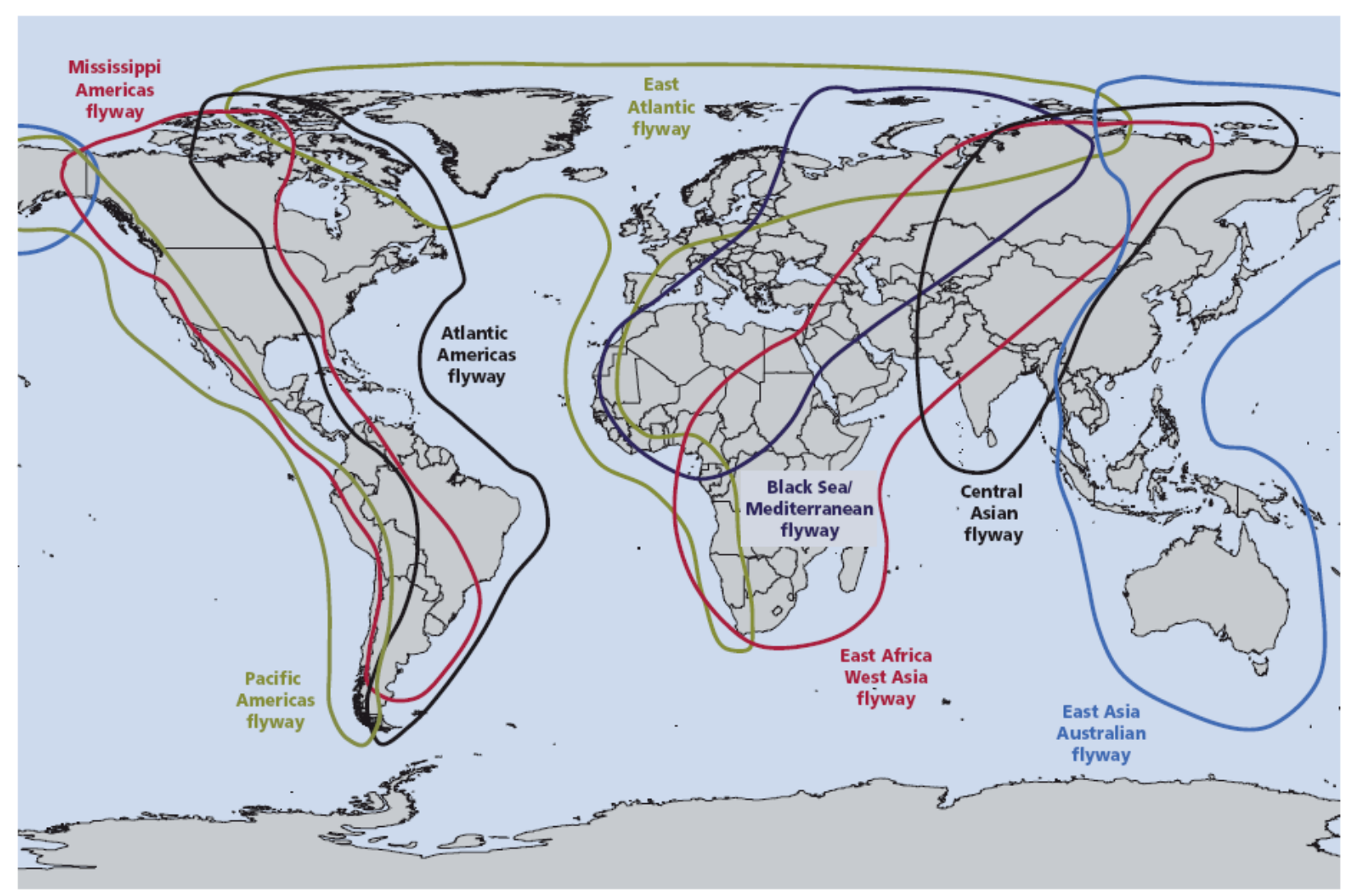

llustração 5- Principais rotas migratórias ("flyways") de aves que se deslocam entre as áreas de reprodução no verão e as áreas de invernada, ligando os hemisférios norte e sul (Boere e Stroud, 2006).

Todo ano, com a aproximação da primavera ou outono, milhões de aves deixam suas frias áreas de reprodução em busca de locais com temperaturas mais amenas e com maior disponibilidade de alimento (áreas de invernada), para depois retornarem às suas áreas de origem durante a primavera e verão, completando assim seu ciclo biológico. Muitas espécies de aves migratórias, tanto de visitantes setentrionais (aves Neárticas), que possuem seus sítios de reprodução no hemisfério norte, como meridionais (aves Neotropicais), que reproduzem em áreas do hemisfério sul, migram para a região Neotropical (da qual o Brasil faz parte), porque nos trópicos há maior abundância de alimentos, em contraste com o rigoroso outono e inverno dos países situados nos extremos dos hemisférios, nos quais os territórios, em grande parte, ficam cobertos por gelo. São conhecidas atualmente 164 espécies de aves migratórias no Brasil, das quais 87 são vindas do hemisfério norte, 67 do hemisfério sul e 10 do oeste. Algumas espécies permanecem em nosso País durante todo o período de invernagem; outras têm no Brasil um ponto de parada e continuam suas migrações até o extremo sul do continente sul-americano. Neste 
período descansam, realizam a troca de penas e se alimentam, refazendo-se de um esforço de migração que é extremamente desgastante. Algumas espécies de maçaricos e batuíras, por exemplo, chegam a realizar trajetos de cerca de dez mil quilômetros entre suas áreas de origem e o nosso País, aqui chegando com cerca de metade de seu peso original (Sick, 1997).

Os habitats selecionados pelas aves migratórias ao longo de suas rotas são diversos e estão relacionados aos hábitos alimentares, disponibilidade de recursos e táticas de forrageamento. Devido à distribuição não-contínua desses recursos, as espécies migrantes geralmente se concentram em áreas específicas. Esses locais têm importância fundamental para conservação dessas espécies, uma vez que, ao realizarem grandes migrações, elas necessitam de áreas chave para trocarem as penas, se alimentarem e adquirirem as reservas energéticas necessárias para a continuação das longas viagens (Centro Nacional de Pesquisa para Conservação das Aves Silvestres - CEMAVE, 2006).

Os locais de concentração de aves migratórias, além da relevância para a conservação das aves, também são importantes no contexto de vigilância epidemiológica dos países, pois é fundamental a realização do monitoramento dessas áreas, para a detecção de possíveis portas de entrada de vírus exóticos no país e a prevenção da disseminação desses agentes e da ocorrência de epidemias.

A porção norte do Brasil é a porta de entrada dos migrantes setentrionais no país. Dessa forma, a Amazônia e zona costeira da região Norte e Nordeste são locais com muitos registros de espécies migratórias do hemisfério norte. Essas aves chegam ao país entre agosto e outubro e retornam para suas áreas de reprodução entre março e maio (Harrington, 1986)

Entretanto, parte das espécies limícolas não segue a migração pela costa, mas pelo interior do continente. Essas espécies passam pela Venezuela e Colômbia, entrando na Amazônia brasileira, principalmente na porção ocidental ( $A M, A C, R O$ e MT) seguindo o caminho de grandes rios (ex. Rio Negro, Branco, Madeira) (Sick 1983), e também a oeste pelo rio Araguaia e Xingu. Essas espécies passam pelo Brasil central, seguindo até o sul do Brasil (Ilustração 6) ou até mesmo à Terra do Fogo (CEMAVE, 2006). 


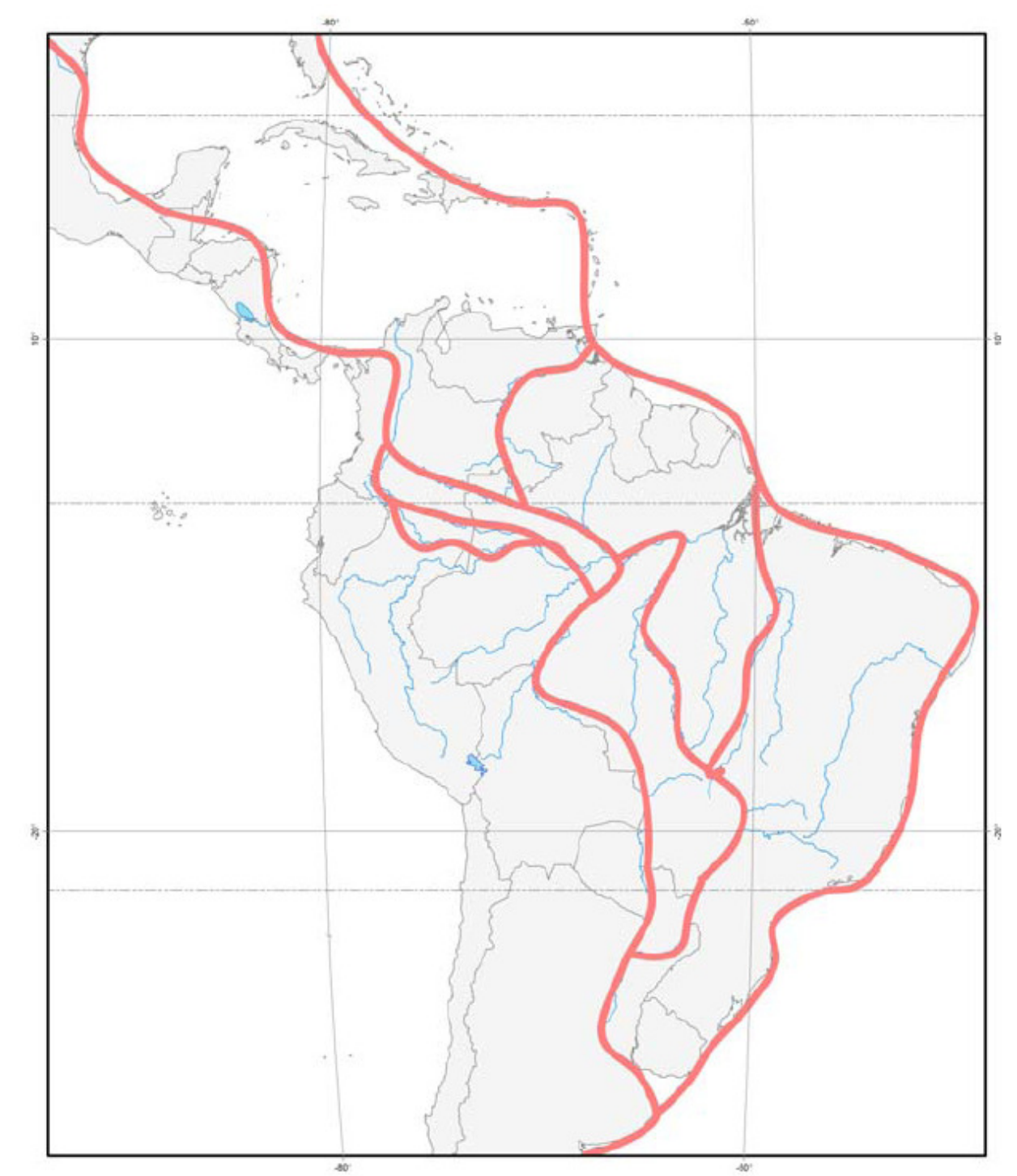

llustração 6- Principais Rotas Migratórias que passam pelo Brasil. Rotas costeiras acompanham a linha da costa, enquanto as rotas interiores acompanham os grandes rios amazônicos (CEMAVE, 2006).

Não existem relatos de rotas migratórias (com áreas de invernagem em terra) que partam dos continentes Europeu ou Asiático e cheguem diretamente ao Brasil (ver llustração 5). A grande maioria dos casos que realizam o trajeto Europa-Brasil é de aves que os ornitólogos chamam de "indivíduos vagantes", ou seja, aqueles que por algum motivo (como desorientação) saem de sua rota normal de migração e chegam a locais inusitados. Por isso, acreditamos que caso a DNC chegue ao país por intermédio de aves migratórias, provavelmente sua entrada dar-se à por rotas provenientes da América do Norte ou provenientes de países da América Latina, alguns considerados endêmicos da doença. 


\subsection{Doença de Newcastle}

\subsubsection{Histórico}

A história da Doença de Newcastle (DNC) começou em 1926 com a descrição de uma doença altamente patogênica em dois pontos geográficos em diferentes lados do mundo, Newcastle-on-Tyne na Inglaterra e a ilha de Java, hoje parte da Indonésia (Doyle, 1927 e Kraneveld, 1926 apud Alexander, 2001). O termo DNC foi criado pelo próprio Doyle (1927) que estudava um surto da doença que ocorreu numa fazenda de frangos em Newcastle-on-Tyne na primavera daquele mesmo ano.

\subsubsection{Patologia}

A Doença de Newcastle é considerada uma das maiores causas de perdas econômicas da avicultura mundial, sendo que para alguns autores ela é considerada uma das doenças animais mais importantes (Alexander, 2001). É uma enfermidade viral aguda, notificável, altamente contagiosa que acomete aves silvestres e comerciais. Os sinais clínicos podem variar entre quadros gastrointestinais agudos, acompanhados de anorexia, letargia e cianose, até conjuntivite, edemas, diarréia (fezes esverdeadas) e doença respiratória aguda com exudatos em trato respiratório superior e dispnéia, ou ainda doença crônica de sistema nervoso central com opistótono, torcicolo, tremores e paralisia de membros (Zanetti, 2005). A manifestação clínica e a mortalidade variam segundo a patogenicidade da amostra do vírus e a espécie aviária infectada. Infecções pelo NDV já foram estabelecidas em pelo menos 241 espécies de aves, representando 27 das 50 ordens da classe (Alexander, 2004). O NDV é mais severo em galinhas, guinés, faisões, codornas e pombos, pode ser encontrado em uma forma mais branda em perus, patos e gansos; ser carreado por pássaros, canários, psitacídeos e outras aves silvestres; podendo, ainda, não apresentar qualquer sinal clínico da doença (Center for Infectious Disease Research \& Policy - CIDRAP, 2003). Muitos subtipos sorológicos de NDV têm sido isolados de aves aquáticas silvestres assintomáticas, por isso acredita-se que as aves silvestres, especialmente as aquáticas, são os reservatórios naturais do vírus, e que possuem um importante papel como agentes transmissores na disseminação da doença para as aves domésticas (Alexander, 1995; Deibel, 1985). Tradicionalmente a patogenicidade pode ser medida por testes biológicos e 
variar como muito alta, intermediária e muito baixa, e ser classificada, respectivamente: amostra velogênica, mesogênica e lentogênica (Jones, 2006). Atualmente, métodos moleculares baseados na reação em cadeia da polimerase (PCR), seqüenciamento de nucleotídeos, e dedução da seqüência de aminoácidos no sítio de clivagem da proteína de fusão $(F)$ também têm sido utilizados para determinar a virulência de novos isolados (Jestin, 1991; Seal, 1995; Wise, 2004).

Testes de inoculação em pintos de 1 dia e em ovos embrionados de galinha, livres de patógenos específicos (SPF), tais como o índice de patogenicidade intracerebral (IPIC), índice de patogenicidade intravenosa (IPIV), ou tempo médio de morte de embrião (TME), permitem caracterizar e classificar o vírus da Doença de Newcastle (NDV) em 5 patótipos mais bem definidos. Por patótipo entende-se o grau de patogenicidade do vírus e, portanto, severidade da doença causada por determinada cepa do vírus. Cepas altamente patogênicas do NDV pertencem aos patótipos denominados: 1) Viscerotrópico e velogênico ou também conhecida como "forma de Doyle" que causa doença severa e fatal com alta mortalidade em galinhas e os principais sintomas são apatia, diarréia esverdeada e lesões hemorrágicas principalmente nos intestinos; 2) Neurotrópico e velogênico ou "forma de Beach" que provoca problemas respiratórios como espirros e corrimento nasal ou ruído dos pulmões, inchamento da cabeça e face, fraqueza, sintomas nervosos como torcicolo, paralisia das pernas e tremores musculares e finalmente ocorre mortalidade, a qual pode chegar até a 100\% das aves; 3) Outros patótipos já menos patogênicos são os vírus classificados como mesogênicos, ou "forma de Beaudette", que podem causar apenas leves sintomas respiratórios nas aves, queda de postura em poedeiras e eventualmente podem ocorrer também sintomas nervosos, mas a mortalidade das aves é normalmente baixa e mais comum em aves jovens; 4) Lentogênicos, ou "forma de Hittchner" são comumente usadas como cepas vacinais e podem causar sintomas respiratórios brandos em aves jovens dependendo da cepa vacinal utilizada; 5) Há ainda um último tipo, não patogênico, conhecido como entérico assintomático, que não causa sintomas ou lesões nas aves e também tem sido utilizado como cepa vacinal. Portanto, nem todas as cepas do vírus de Newcastle causam doença (Beard, 1981). 


\subsubsection{Classificação}

De acordo com a Organização Mundial de Sanidade Animal (Office International des Epizooties - OIE), da qual o Brasil é signatário, "A Doença de Newcastle é uma doença infecciosa das aves causada por um Paramyxovirus aviário do sorotipo 1 (APMV1) que apresenta um dos seguintes critérios de virulência: a) o vírus tem um índice de patogenicidade intra-cerebral de pelo menos 0,7 em pintos de um dia; ou b) a presença de múltiplos aminoácidos básicos (arginina ou lisina) é demonstrada no vírus (diretamente ou por dedução), em determinadas regiões da proteína de fusão (F0)". Estes critérios é que caracterizam a ocorrência de doença, definindo assim as áreas que oferecem risco ou não de levarem e introduzirem a doença em regiões ou países considerados não endêmicos, como o Brasil. Com isso, determina-se também o estabelecimento de barreiras sanitárias no comércio interno e externo de aves e subprodutos avícolas, acarretando em enorme prejuízo econômico aos países com notificação da DNC (OIE, 2004).

Conforme o International Committee on Taxonomy of Viruses (ICTVdB, 2008), o agente viral pertence à ordem Mononegavirales, família Paramyxoviridae, gênero Avulavirus, espécie Avian paramyxovirus tipo 1 (APMV-1) também conhecido por vírus da Doença de newcastle (newcastle desease virus - NDV). A relação filogenética do NDV com os outros paramyxovirus (membros da família Paramyxoviridae) pode ser observada na llustração 7. Até o momento, baseado em mapeamento de sítios de enzimas de restrição do gene $\mathrm{F}$ codificador da proteína de fusão e análises filogenéticas tanto dos genes de proteína $F$ como da proteína $H N$, foram descritos nove genótipos (I a IX) compreendendo linhagens epizoóticas em todo o mundo (Liu, 2006; Liu, 2008; Ujvári, 2003; Wehmann, 2003). 


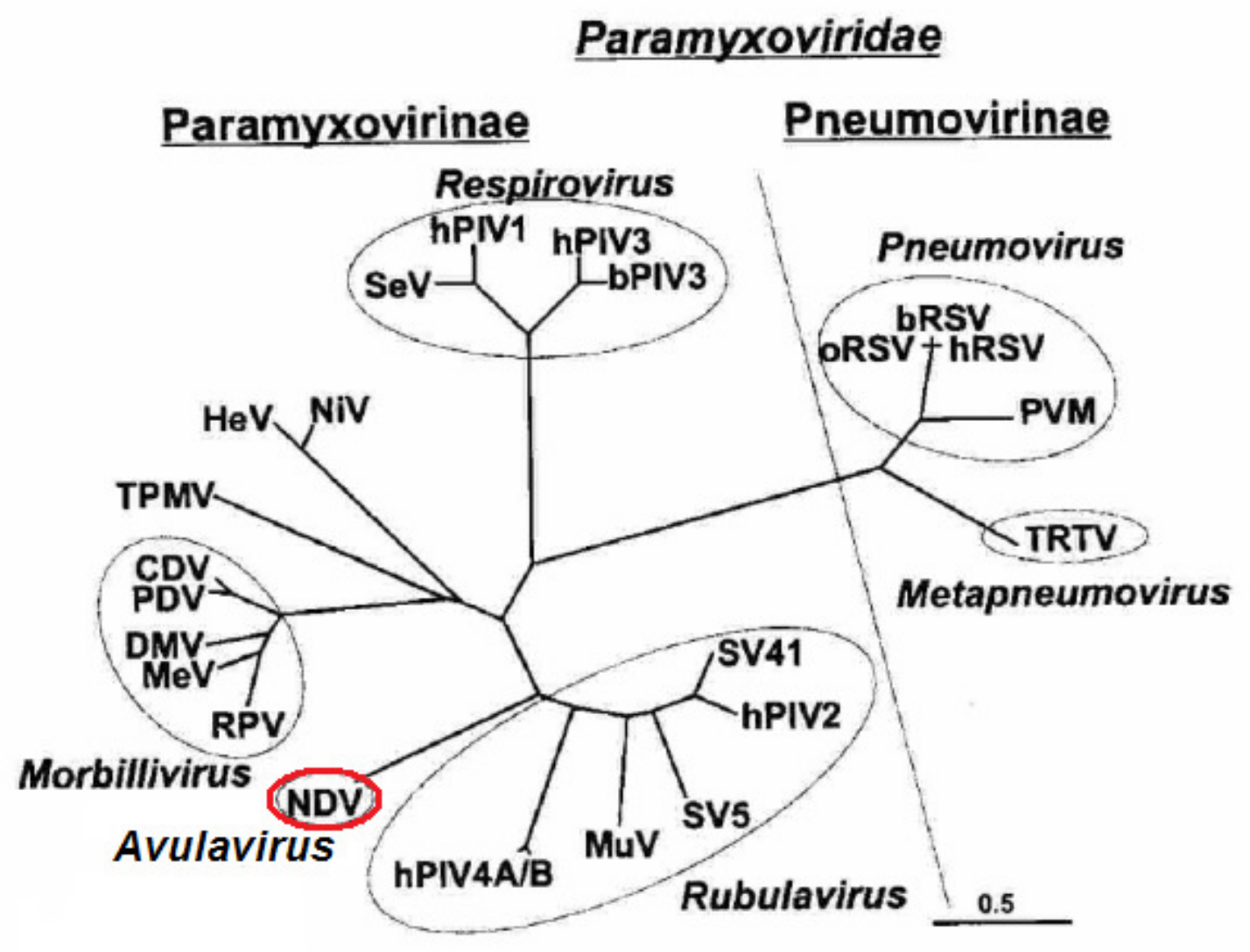

llustração 7- Classificação dos membros da familia Paramyxoviridae (adaptado de Collins, 2001).

Dentro do gênero Avulavirus, existem outros oito sorotipos de paramyxovirus aviários (APMV-2 ao APMV-9, não mostrados na llustração 7), a maioria deles parece ocorrer naturalmente principalmente em aves aquáticas, embora outras espécies aviárias possam ser suscetíveis. APMV-2 e 3 podem causar doenças respiratórias e perdas na produção de ovos, principalmente em perus (Westbury, 2001).

\subsubsection{Características estruturais e genéticas}

NDV é um vírus envelopado, fita simples de RNA, polaridade negativa, com morfologia esférica ou pleomórfica de aspecto rugoso e tamanho variando de 150 a 350nm de diâmetro (llustração 8). 


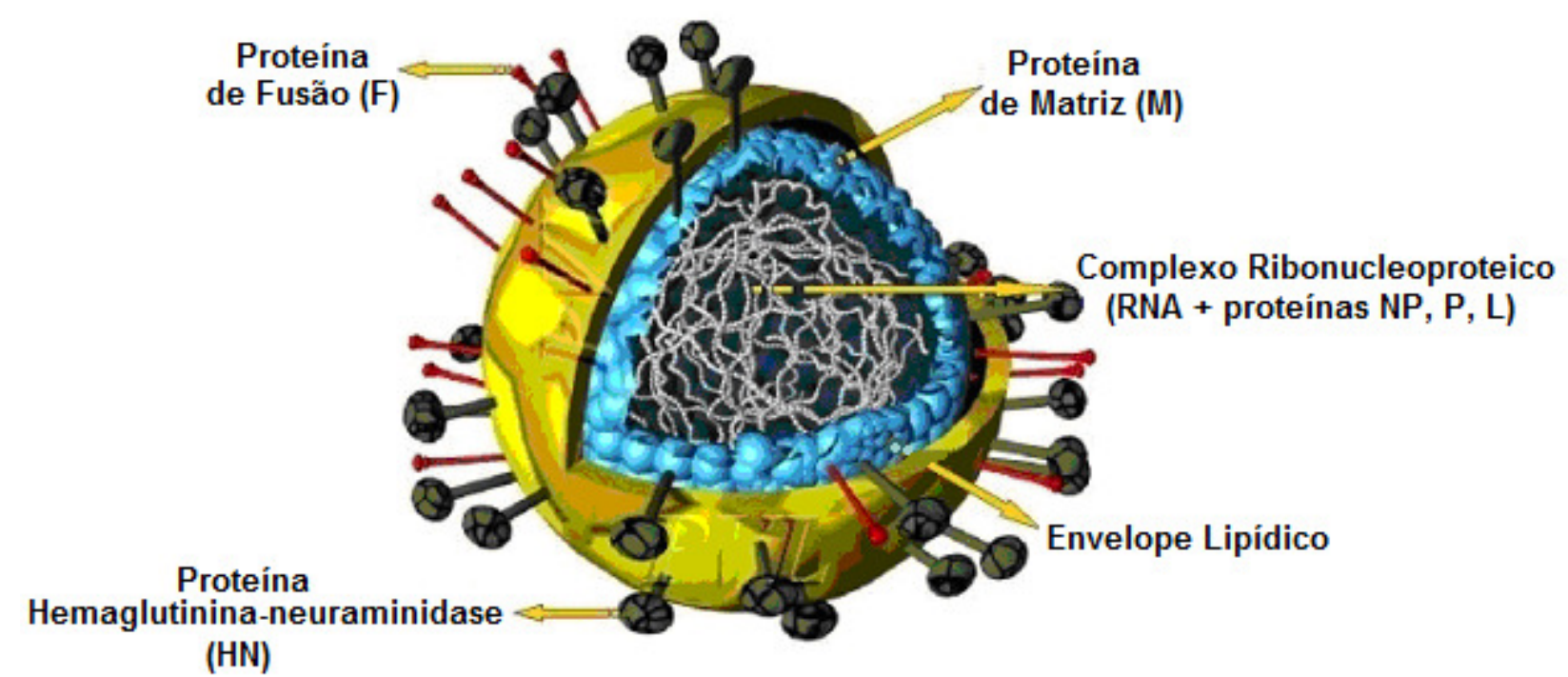

llustração 8- Modelo representativo dos vírus da família paramyxoviridae (alterado de "The Big Picture Book of Viruses" - http://www.tulane.edu/ dmsander/Big_Virology/BVHomePage.html)

O genoma viral (Ilustração 9) do NDV possui tamanho aproximado de 15.186 nucleotídeos e contem 6 genes que codificam seis polipeptídios. O envelope lipídico contém duas glicoproteínas de superfície, proteína de fusão $(F)$ e hemaglutininaneuraminidase $(\mathrm{HN})$, ao redor da partícula viral, que medeiam a entrada e saída viral de suas células hospedeiras. Dentro do envelope existe um nucleocapsídeo helicoidal central contendo o RNA genômico e as proteínas: do nucleocapsídeo (NP), fosfoproteína (P) e a grande polimerase RNA-dependente $(\mathrm{L})$, que iniciam a replicação viral intracelular. Há ainda entre o envelope e o núcleo viral a proteína de matriz (M), que é importante na arquitetura da partícula viral e que é liberada do núcleo durante a entrada do vírus na célula hospedeira (Millar, 1988).

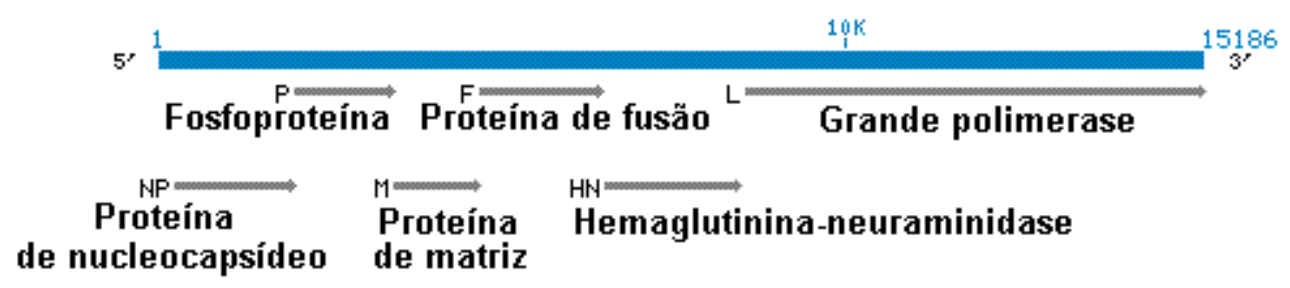

Ilustração 9- Esquema do genoma do NDV em bases, mostrando a posição dos 6 genes codificadores das proteínas virais (adaptado de PubMed - NCBI homepage - http://www.ncbi.nlm.nih.gov). 


\subsubsection{Replicação}

O RNA genômico de todos os vírus de RNA fita-negativa têm de servir a duas funções: primeiro como substrato para a síntese de mRNAs (RNA mensageiros), e segundo como substrato para a síntese da fita positiva antigenômica. Vírus de RNA fita-negativa codificam e carregam sua própria RNA polimerase, porém mRNAs só são sintetizados depois que os vírus infectam as células. A replicação viral ocorre inteiramente no citoplasma (Lamb, 1996).

A adesão da partícula viral à célula hospedeira se dá por intermédio de suas proteínas de superfície $\mathrm{HN}$, que é uma proteína multifuncional e o principal determinante antigênico dos paramyxovirus. HN é responsável pela adsorção do vírus às moléculas de ácido siálico contidas na superfície celular e por sua clivagem (atividade de neuraminidase), analogamente ao papel da proteína neuraminidase (NA) do vírus influenza, para prevenir a auto-agregação das partículas virais durante o brotamento na membrana citoplasmática. Além disso, HN possui atividade promotora na proteína de fusão (F) (Lamb, 2007).

A penetração do vírus ocorre devido a fusão do envelope viral e a membrana plasmática celular, em pH neutro, causada pela proteína F. Como conseqüência, o nucleocapsídeo é liberado no citoplasma e, depois de entrar e sofrer o desnudamento, RNAs virais encapsulados são transcritos pela RNA polimerase RNA-dependente associada ao nucleocapsídeo para produzir mRNAs, que serão traduzidos em proteínas virais. Estes catalisam a replicação do RNA através da síntese de nucleocapsídeos antigenômicos. A replicação produz mais nucleocapsídeos genômicos para adicionais transcrições e traduções de genes virais, e para a montagem, com proteínas estruturais, de partículas virais progenitoras. O ciclo total de replicação do NDV está esquematizado, na Ilustração 10, a seguir. 


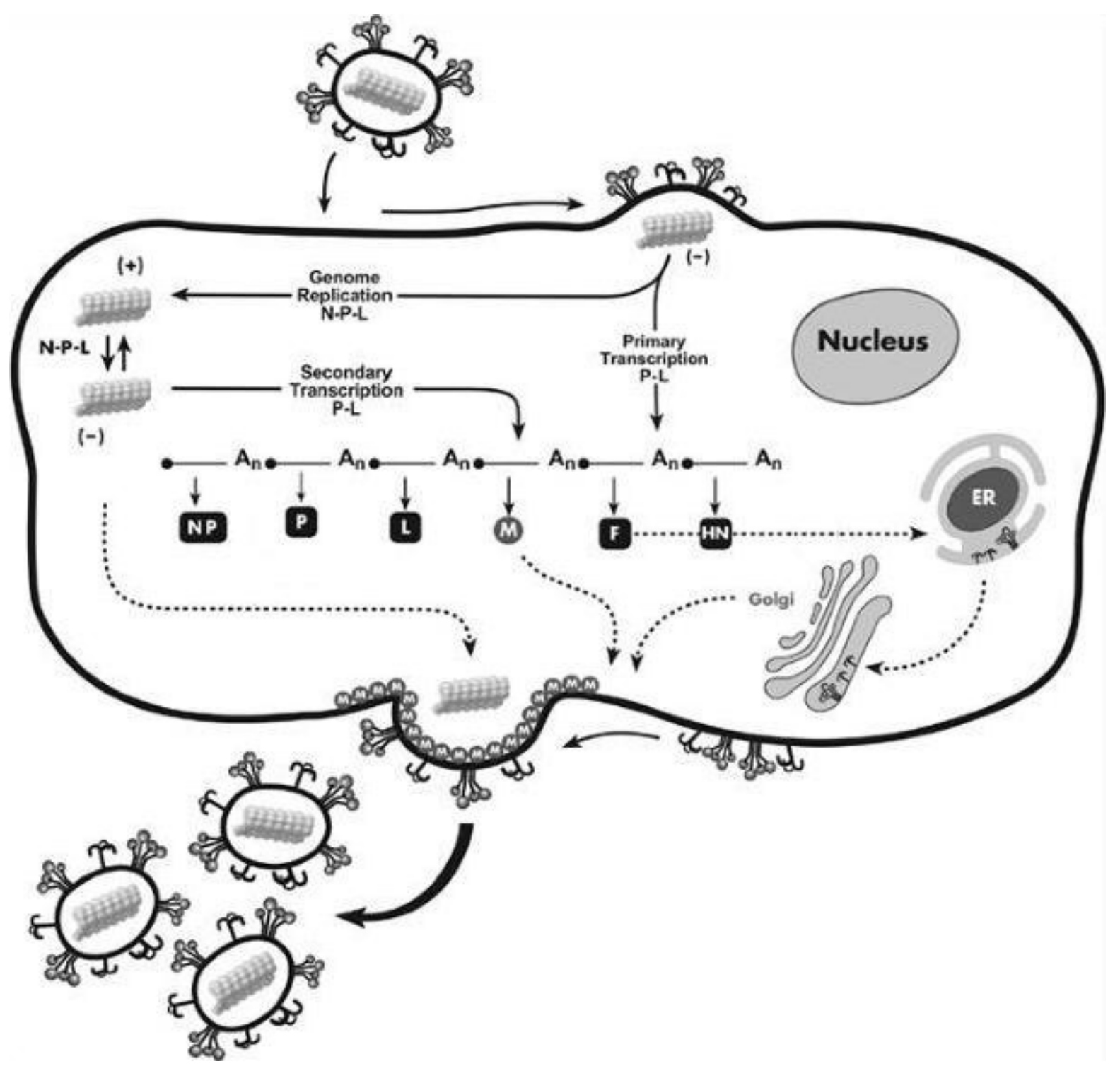

llustração 10- Representação esquemática do ciclo de vida dos paramixovirus. O topo da llustração mostra a chegada de uma partícula viral que se funde à membrana citoplasmática para liberar o nucleocapsídeo, contendo o RNA de fitas negativas, no citoplasma. Os RNAs mensageiros (mRNAs) virais estão indicados por linhas com o cap representado por um circulo preenchido e a cauda poli $A$ por $A_{n}$. $O$ gradiente da diminuição da molaridade dos mRNAs de NP para $L$ devido a transcrição polar não está ilustrada. Também não está ilustrado a abundância relativa do genoma negativo versus o antigenoma (+). Linhas sólidas representam a transcrição primária e secundária realizada pelo complexo $\mathrm{P}-\mathrm{L}$ e a replicação genomica realizada pelo complexo N-P-L. Linhas pontilhadas representam o transporte intracelular do nucleocapsídeo e da proteína $\mathrm{M}$ para a membrana plasmática, e as glicoproteínas virais $\mathrm{F}$ e $\mathrm{HN}$ do retículo endoplasmático (ER) para o Golgi e para a membrana plasmática. A grande seta representa a liberação dos novos vírus gerados por brotamento na membrana plasmática (Alterado de Lamb, 2007). 
Além da fusão viral-celular, a proteína $F$ inserida na membrana plasmática de células infectadas pode causar sincícios, mediante a fusão com células vizinhas, ao longo da infecção. Este efeito citopático pode levar à necrose do tecido in vivo e imagina-se tratar de um mecanismo de disseminação viral.

No caso do NDV, a proteína F também é importante por estar correlacionada à virulência do vírus. Linhagens com múltiplos resíduos básicos no sítio de clivagem F0 são linhagens virulentas e rapidamente se disseminam pelo hospedeiro, enquanto que linhagens com a molécula F0 contendo apenas um único resíduo básico são avirulentas e tendem a permanecerem restritas ao trato respiratório onde a protease secretada pode ser encontrada (Nagai, 1977).

A proteína $\mathrm{F}$ é um homotrímero que é sintetizada como um precursor (F0). Para ser biologicamente ativa, ela precisa ser clivada pela protease da célula hospedeira no sitio de ativação da clivagem. A clivagem libera o novo N-terminal de F1, formando assim a proteína biologicamente ativa, que consiste de cadeias de dissulfuretos-ligados F1 e F2 (é importante ressaltar que F1 e F2 não são domínios separados na estrutura atômica de F e, portanto, não são partes individuais da proteína). A ativação proteolítica de Fo envolve a ação seqüencial de duas enzimas, uma protease que cliva o lado carboxílico de um resíduo arginina, e uma carboxilpeptidase que remove os resíduos básicos. F0 com múltiplos resíduos básicos no sitio de clivagem facilitam a ação de proteases intracelularmente durante o transporte da proteína através do complexo de Golgi, e assim, interfere na habilidade de proteases celulares específicas de clivar a proteína de diferentes patótipos, resultando em uma infecção sistêmica fatal (Gotoh, 1992; Ogasawara, 1992).

Paramyxovirus que possuem proteína $\mathrm{F}$ com um único resíduo básico no sítio de clivagem, geralmente não são clivados quando crescem em culturas de tecidos celulares e, por isso, apenas um único ciclo de crescimento é obtido. Contudo, o precursor F0 que é expresso na superfície celular e incorporado aos vírus liberados pode ter sua clivagem ativada pela adição de protease exógena, permitindo múltiplas rodadas de replicação (Lamb, 2007). 


\subsubsection{Epidemiologia}

A DNC é considerada de distribuição mundial, com áreas endêmica, ou consideradas livres da doença. O NDV virulento é endêmico e causa freqüentes epidemias na África, Ásia, América Central e partes da América do Sul e do Oriente médio. Graves epidemias recentes aconteceram na Dinamarca em 2002 e na Califórnia em 2003. Desde então, epidemias têm ocorrido na Áustria, Barém, Bulgária, Finlândia, Grécia, Itália, Japão, Noruega, África do Sul, Suécia, Tailândia e Venezuela (OIE, 2004).

A infecção pode ocorrer através da inalação ou ingestão, sendo que o vírus está presente no ar exalado pelas aves, nas fezes e em toda parte da carcaça da ave durante a infecção aguda e na morte. A contaminação de outras aves pode se dar por meio de aerossóis e pela ingestão de água ou alimentos contaminados. Quanto à transmissão vertical do vírus, parece não ocorrer, a maioria das aves infectadas cessam a oviposição e se o ovo se infectar o embrião sucumbirá. A intervenção humana é provavelmente o método mais comum de infecção em aviários industriais, as roupas e sapatos de pessoas que manuseiam aves infectadas são imediatamente contaminados. Assim como a comida, água e equipamentos usados ou expostos a áreas contaminadas são, também, um meio mecânico de disseminação do vírus contagioso. O período de incubação nas aves é de aproximadamente cinco dias, mas pode variar de 2 a 15 dias (Jones, 2006).

\subsubsection{Diagnóstico}

Por apresentar sintomatologia comum a outras doenças, a DNC pode ser confundida com diversas enfermidades, porém deve-se lembrar que a Doença de Newcastle gera alta mortalidade e sendo assim poderemos eliminar diversas das doenças do Diagnóstico Diferencial (DD). Dentre as enfermidades que poderão ser suspeitas são: Bronquite Infecciosa, Pneumovirose, Laringotraqueíte, Influenza Aviária, Encefalomielite, Doença de Marek (apenas pela paralisia), Doença de Pacheco, Coriza Aviária, Cólera, Psitacose e outras.

Todas as linhagens de NDV aglutinam eritrócitos de galinha in vitro (e às vezes hemácias de outras espécies). Este processo é conhecido como 
hemaglutinação e serve de base para o teste sorológico de inibição da hemaglutinação $(\mathrm{HI})$, usado para detectar anticorpos contra este vírus.

O diagnóstico laboratorial do vírus pode ser realizado pela inoculação de macerados de órgãos de aves suspeitas em ovos embrionados ou por testes moleculares, como RT-PCR. A confirmação do isolamento viral é feita por testes de HI, que permite também o diagnóstico diferencial de vírus de influenza aviária. Amostras virais identificadas como Newcastle, isoladas em ovos a partir de surtos em que ocorra a suspeita da doença devem ser então testados in vivo em pintos ou por seqüenciamento de DNA para determinar a patogenicidade da amostra isolada (MAPA, 2006). A detecção direta do vírus pode ser efetuada por imunohistoquímica, imunoperoxidase e hibridização in situ (Brown, 1999).

\subsubsection{Prevenção}

Países exportadores estabelecem monitorias constantes da doença, para avaliar a sua situação assim como tentar evitar a entrada da doença no país. Em muitos países, incluindo o Brasil, a doença vem sendo controlada em plantéis comerciais através da vacinação, com vacinas aprovadas e com controle de qualidade verificado pelo MAPA.

Em alguns Estados são vacinadas apenas as matrizes para transferência de imunidade materna às progênies. A queda completa do nível de anticorpos que ocorre na idade de abate de frangos de corte tem sido utilizada como uma forma de verificar se há vírus circulando em determinada região (MAPA, 2006).

Vacinas vivas de cepas $B_{1}$ e La Sota são administradas nos bebedouros ou em forma de sprays, mas também podem ser administradas de forma intranasal ou intraocular. Pintos saudáveis podem ser vacinados tão cedo quanto 1-4 dias de vida, porém atrasando a vacinação até a segunda ou terceira semana aumenta a eficiência. Existem também vacinas inativadas que são mais seguras, porém possuem a inconveniente necessidade de aplicação por meio de injeção individual (Alexander, 1991).

No Brasil, assim como em outros países signatários da OIE, a comunicação em caso da DNC é compulsória, e deve-se seguir uma série de ações profiláticas sanitárias, baseadas em amparo legal. O Decreto № 24.548 (1934) discorre sobre 
medidas de prevenção, controle e erradicação de doenças exóticas, incluindo o sacrifício de aves e a indenização dos proprietários. E a Instrução Normativa №32 (2002) da Secretaria de Defesa Agropecuária impõe: a notificação obrigatória ao Serviço Veterinário Oficial de sintomatologia suspeita, realização de investigação imediata por um médico veterinário oficial, imposição de restrição à movimentação de aves e seus produtos em casos suspeitos, estabelecimento por ato oficial de uma Zona de Proteção (num raio de $3 \mathrm{~km}$ do surto) e de Zona de Vigilância (num raio de $10 \mathrm{~km}$ do surto), controle da movimentação das pessoas na área de risco, o sacrifício de todas as aves e animais-contato do estabelecimento infectado, a limpeza e desinfecções constantes da área afetada e o descarte adequado dos resíduos, entre outras normas, seguindo o fluxograma abaixo (Ilustração 11).

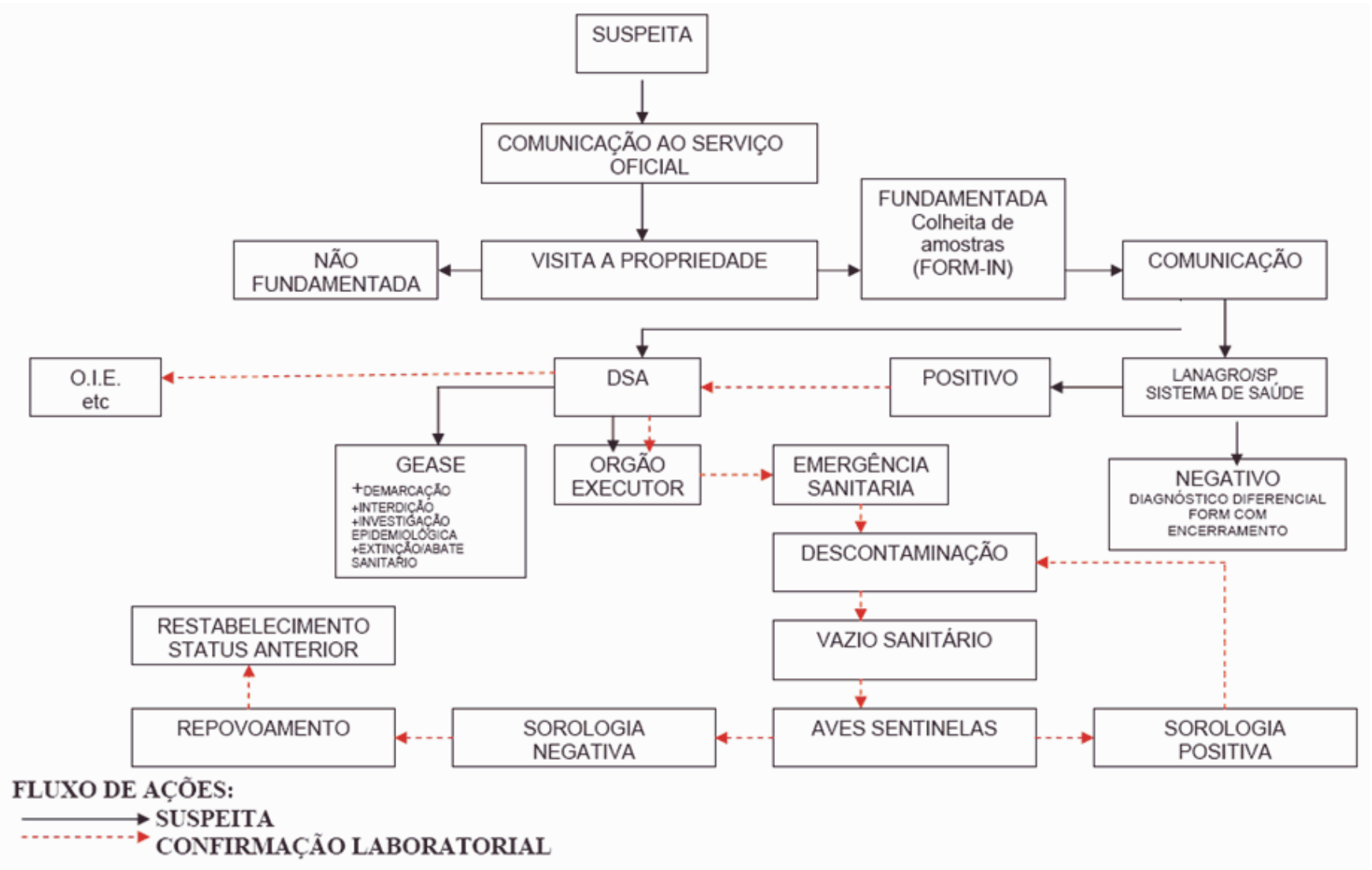

Ilustração 11- Fluxograma de ações no caso de suspeita de DNC, Departamento de saúde animal (DSA). 


\subsection{Histórico da DNC no Brasil}

O histórico da DNC no Brasil começou com o aparecimento dos primeiros surtos da Doença de Newcastle em Belém do Pará e em Macapá, capital do Amapá, em 1953 (Santos, 1954 apud Franzo, 2007), sendo que sua introdução ocorreu, aparentemente, por meio da importação de carcaças congeladas de aves de corte procedentes dos Estados Unidos da América para um dos hotéis da capital paraense (Vaitsman e Moussatché, 1954 apud Franzo, 2007). Nessa ocasião Cunha e Silva (1955) realizaram o isolamento da amostra M33 do vírus 83 da Doença de Newcastle nestas carcaças. A partir desta data, a doença foi observada em todo o território nacional, ocasionando graves perdas econômicas para os avicultores brasileiros (Hastenreiter, 1976; Ito, 1986). Também foram assinalados inúmeros surtos e/ou casos da enfermidade em aves reprodutoras, comerciais, criadas em galinheiros domésticos e/ou em aves caipiras (Silva, 1961; Oliveira e Girão, 1979; Oliveira, 1981), os quais proporcionaram elevados prejuízos à avicultura nacional, inclusive com o comprometimento do comércio internacional de produtos de origem avícola, particularmente, no ano de 1995 (Folha de São Paulo, 1995). Entretanto, a patogênese e a epizootiologia das estirpes do NDV que acometeram o plantel avícola brasileiro, em toda a sua história, permanecem ainda obscuras.

No ano de 1999, estudos sorológicos indicaram a circulação do NDV em aves silvestres no Estado do Rio de Janeiro (Bellucci, 1999), e em junho de 2001, o MAPA reportou um surto no Estado de Goiás, que foi prontamente controlado (OIE Disease Information Report, 2001).

Considerada endêmica por mais de 50 anos em várias regiões, em 2003, o governo brasileiro declarou o país livre desta doença, com reconhecimento da OIE, a partir de um levantamento oficial realizado em 2002 (MAPA, 2006) e só depois disso o Brasil ultrapassou os Estados Unidos e tornou-se o maior exportador mundial de frango.

Porém em maio de 2005, o MAPA reportou a morte de 6.000 frangos em Jaraguari no Estado do Mato Grosso do Sul que subsequentemente atribuiu-se a uma linhagen vacinal de NDV. Em julho de 2006, o Department of Environment Food and Rural Affairs (DEFRA) publicou um relatório internacional relatando o surto mais recente da DNC no Brasil. Foi um surto do vírus da Doença de Newcastle com índice de patogenicidade de 1,41 que foi reportado em frangos de "fundo de quintal" no 
estado do Rio Grande do Sul, em maio daquele mesmo ano. As medidas de contenção foram prontamente atendidas e o surto não se estendeu às criações comerciais (OIE, 2006). Neste mesmo ano, também foi relatada a ocorrência de doença de Newcastle em um pato numa propriedade localizada próximo ao parque industrial de Manaus, no Amazonas. O caso foi identificado durante atividades de monitoramento para influenza aviária e doença de Newcastle em propriedades com populações avícolas de subsistência, localizadas no raio de $10 \mathrm{~km}$ ao redor de sítios de invernada de aves migratórias (CNA, 2006).

\subsection{Antártica}

Apesar de existirem poucas rotas migratórias de aves que liguem a Antártica diretamente ao Brasil e vice-versa, estudos demonstram que a Antártica é uma região de relativa diversidade animal e que tem sido infectada com uma variedade de viroses aviárias incluindo paramixoviroses, vírus da influenza e NDV entre outros (Morgan, 1981; Wallensten, 2006; Morgan, 1988). Além disso, a Antártica não é tão remota quanto parece, uma grande proporção de uma variedade de espécies aviárias migram de latitudes maiores para nidificarem lá, incluindo procelares, cormorantes e andorinhas marinhas (Wallensten, 2006).

A Antártica é uma região considerada internacional e está sujeita a acordos internacionais, dispostos em 14 artigos dentro do Tratado da Antártida. Trata-se de um documento firmado em 1 de Dezembro de 1959, pelos países que reclamavam a posse de partes do continente da Antártica, em que se comprometem a suspender suas pretensões por período indefinido, permitindo a liberdade de exploração científica do continente, em regime de cooperação internacional. $O$ tratado possui um regime jurídico que estende a outros países, além dos 12 iniciais, a possibilidade de se tornarem partes consultivas nas discussões que regem o "status" do continente quando, demonstrando o seu interesse, realizarem atividades de pesquisa científica substanciais (Scientific Committee on Antarctic Research - SCAR, 2008).

No ano de 1975, o Brasil aderiu ao Tratado da Antártica, e sete anos depois realizou sua primeira expedição ao continente Antártico, com a criação do Proantar pelo governo brasileiro. A primeira expedição ocorreu entre os verões de 1982/1983. 
Faziam parte desta expedição os Navios "Barão de Teffé", da marinha do Brasil e "Prof. Wladimir Besnard", do Instituto Oceanográfico da Universidade de São Paulo. Com os bem sucedidos resultados da expedição, fizeram com que o Brasil, em 1984, fosse aceito como membro pleno do Comitê Científico sobre Pesquisa Antártica (Folha de São Paulo, 2002).

Em 1986,foi fundada a Estação Antártica Comandante Ferraz (EACF), que está situada mais precisamente na península Keller na Ilha Rei George. A península Keller $\left(62^{\circ} 08 \mathrm{~S}, 58^{\circ} 25 \mathrm{~W}\right)$ fica na Baía do Almirantado, na ponta da grande península Antártica (Ilustração 12). A Ilha Rei George é a maior da região, distante $120 \mathrm{Km}$ da costa da Antártica e $900 \mathrm{Km}$ do continente Americano. A estação dispõe de todas as instalações necessárias como se fosse uma pequena cidade. O total atual de módulos é de sessenta e oito unidades, com capacidade de viverem confortavelmente 48 pessoas, parecendo uma pequena vila em meio ao gelo antártico. A estação opera durante todo o ano. A estrutura é composta por laboratórios, depósitos, oficinas, biblioteca, salas de lazer e estar, enfermaria, sala de comunicações, ginásio de esportes, cozinha e refeitório. A administração da estação é executada por militares da Marinha do Brasil, que ali permanecem durante um ano, sendo trocados ao final do período (Folha de São Paulo, 2002).

A área costeira da ilha é habitada por elefantes marinhos, lobos e leões marinhos, e diversas espécies de aves incluindo os pingüins. A ocupação humana da Ilha Rei George limita-se às estações de pesquisa pertencentes à Argentina, Brasil, Chile, China, Corea do Sul, Peru, Polônia, Rússia e Uruguai. A maioria das estações é permanente e realizam pesquisas principalmente nas áreas de biologia, ecologia, geologia e paleontologia (SCAR, 2008).

Devido às evidências sorológicas de infecções passadas de pingüins pelo NDV, reportadas por diferentes autores (Morgan, 1981; Wallensten, 2006; Morgan, 1988), o aumento da atividade humana e conseqüente risco de introdução de doenças para a vida selvagem, e a relativa falta de conhecimento acerca do NDV e seus hospedeiros num lugar tão distante e inóspito como a região antártica, a importância de melhor se entender a epidemiologia do NDV dentro e fora do Brasil torna-se proeminente. 


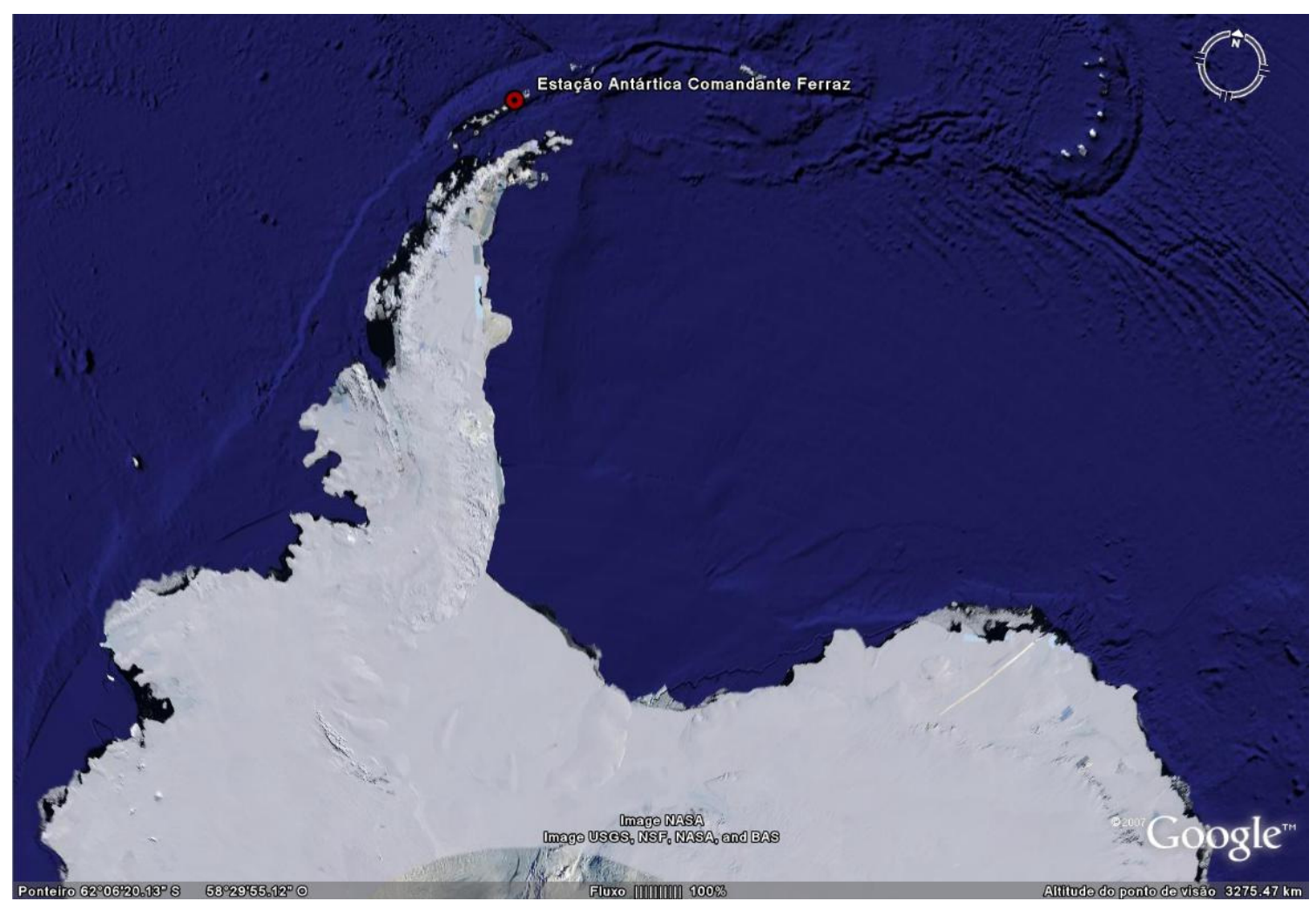

llustração 12- Imagem de satélite, retirado do programa GoogleEarth ${ }^{\mathrm{TM}}$, mostrando a localização da Estação Brasileira Comandante Ferraz, na llha Rei George, na ponta da grande Peninsula Antartica.

\subsection{Considerações finais}

Pelo exposto fica evidente o risco que a DNC pode constituir para a avicultura brasileira e mundial, e por isso, devemos considerar: a importância que a avicultura representa para o país, pela geração de benefícios sociais e econômicos; que o surto desta doença, em um centro de produção avícola, representaria um risco à economia e incidiria de forma negativa nos níveis de consumo de proteína de qualidade e economicamente acessível para as populações; a necessidade de fortalecer os serviços de defesa sanitária animal e aumentar a capacidade da investigação, e finalmente; a importância de atualizar e harmonizar normas e procedimentos para a prevenção e controle da Doença de Newcastle, tendo como referência as recomendações da OIE (OIE, 2005).

Percebe-se que quando uma virose emerge ou reemerge numa região, a falta de experiência e conhecimento dos profissionais com a nova doença e o despreparo para lidar com a nova realidade podem favorecer a disseminação do patógeno (por 
falta de cuidados emergenciais necessários). Somente quando os casos atingem um número crítico é que estas doenças são reconhecidas. Muitas vezes, quando as epidemias são evidenciadas em determinadas comunidades, já ocorreu a disseminação do vírus para outros locais tornando difícil seu controle (Tauil, 2001).

Devido à impossibilidade de distinção dos agentes causadores de infecções respiratórias aviárias apenas pelo quadro clínico, o diagnóstico laboratorial torna-se indispensável. Além disso, a necessidade de se gerar maior conhecimento acerca dos patógenos respiratórios aviários está diretamente relacionada à execução de medidas preventivas de saúde pública e ao controle de vetores, tornando o estudo destes, indispensável para um melhor entendimento dos aspectos etiológicos e epidemiológicos destas doenças. Para isso, nosso objetivo é aperfeiçoar a PCR em Tempo-Real (quick polimerase chain reaction - qPCR) descrita por Wise (2004), para detectar o vírus de Newcastle em amostras coletadas de aves de diferentes regiões do Brasil, com elevada confluência migratória, bem como de pingüins da Antártica, e avaliar seu potencial como nova ferramenta na epidemiologia e etiologia de um dos principais agentes respiratórios aviários.

A qPCR transformou-se no método padrão para a detecção e quantificação de RNAs alvos e está sendo cada vez mais utilizado nos novos ensaios de diagnóstico clínico. Os resultados quantitativos obtidos por esta tecnologia são não somente mais informativos do que dados qualitativos, mas simplificam a estandardização do ensaio e a gerência da qualidade. $O$ desenvolvimento do método de detecção do SARS-CoV por qPCR (Poon, 2003) forneceu um exemplo do valor desta tecnologia para o rápido diagnóstico clínico e por tais motivos foi o método escolhido e utilizado neste trabalho.

Neste estudo, através da qPCR, nós investigamos a presença do NDV em aves domésticas e selvagens saudáveis em áreas geográficas importantes para as aves migratórias no Brasil, consideradas porta de entrada de doenças epizoóticas exóticas. Relatos sobre a ocorrência de NDV nestas regiões são escassos ou inexistentes. Tem-se sugerido que NDVs mantidos em diferentes espécies aviárias silvestres possam estar causando epidemias de NDV em granjas ao redor do mundo. Por isso, consideramos importante procurar pela presença do NDV nestes possíveis reservatórios, bem como em criações aviárias com contato direto com as aves silvestres. Para tal, realizamos um estudo de vigilância epidemiológica do NDV 
em diversas regiões do Brasil, com elevada confluência migratória, ou seja, regiões que estavam na rota das principais rotas migratórias aviárias conhecidas.

A expressão vigilância epidemiológica passou a ser aplicada ao controle das doenças transmissíveis na década de 50, para designar uma série de atividades subseqüentes à etapa de ataque da campanha de erradicação da malária, vindo a designar uma de suas fases constitutivas. Originalmente, significava "a observação sistemática e ativa de casos suspeitos ou confirmados de doenças transmissíveis e de seus contatos". Tratava-se, portanto, da vigilância de pessoas, com base em medidas de isolamento ou quarentena, aplicadas individualmente, e não de forma coletiva.

Na década de 60, o programa de erradicação da varíola também instituiu uma fase de vigilância epidemiológica, subseqüente à de vacinação em massa da população. Simultaneamente, o programa disseminou a aplicação de novos conceitos que se firmavam no âmbito internacional e não se vinculavam à prévia realização de uma fase de ataque. Pretendia-se, mediante busca ativa de casos de varíola, a detecção precoce de surtos e o bloqueio imediato da transmissão da doença.

Neste novo contexto que pretendemos, através deste trabalho, prover informações atualizadas sobre a ocorrência do NDV, bem como fatores que o condicionam em determinadas áreas geográficas e populações definidas, afim de subsidiar o planejamento, organização e operacionalização dos serviços de saúde animal, bem como a normatização das atividades técnicas correlatas, de forma que as medidas de intervenção pertinentes possam ser desencadeadas com oportunidade e eficácia. 


\section{OBJETIVO}

Realizar um estudo de vigilância epidemiológica molecular do NDV (APMV-1), em amostras de swabs colhidos de aves em regiões com elevada confluência migratória aviária no Brasil, como forma de monitoramento do NDV em aves com elevado potencial de sentinelas, ou seja, aves que possuem contato direto com aves migratórias e que podem representar potenciais hospedeiros da doença exótica ao país.

Realizar o mesmo estudo em pingüins capturados ao redor da Estação Brasileira Comandante Ferraz, na Antártica, como forma de monitoramento do NDV também em aves que possuem contato direto com outras aves migratórias fora do país, podendo assim representar potenciais hospedeiros da doença exótica ao Brasil.

Por fim, otimizar a PCR em Tempo-Real (qPCR) para a detecção do NDV, descrita por Wise (2004), adequando-a aos equipamentos e reagentes disponíveis no Brasil, para avaliá-la como ferramenta no monitoramento molecular do NDV. 


\section{MATERIAL E MÉTODOS}

\subsection{Logística}

A vigilância epidemiológica ativa em aves selvagens apresenta obstáculos práticos, logísticos e financeiros que a tornam um desafio. Dada a baixa prevalência esperada dos vírus estudados e os recursos disponíveis limitados para o que são dispendiosos esforços, foi importante traçarmos estratégias claras e definidas tanto nas atividades de campo quanto laboratoriais, para obtermos uma amostragem que indiretamente nos fornecesse dados importantes sobre o monitoramento do NDV, em aves migratórias, no Brasil. Indiretamente, porque realizamos coletas de amostras em poucas aves silvestres, dadas as dificuldades descritas anteriormente; coletamos principalmente de aves domésticas, porém com grande potencial para serem aves "sentinelas". Demos maior ênfase em estudar: espécies que sabidamente já foram infectadas por NDV; espécies que são conhecidas como reservatórios epidemiológicos do NDV (patos domésticos, por exemplo, podem carregar o vírus sem apresentar sintomas); aves que possuíam um maior contato com outras espécies selvagens (migratórias ou não); e aves que compartilhavam o habitat com outros animais, principalmente criadas em "fundo de quintal" ou soltas em lagos (Ilustração 13). 


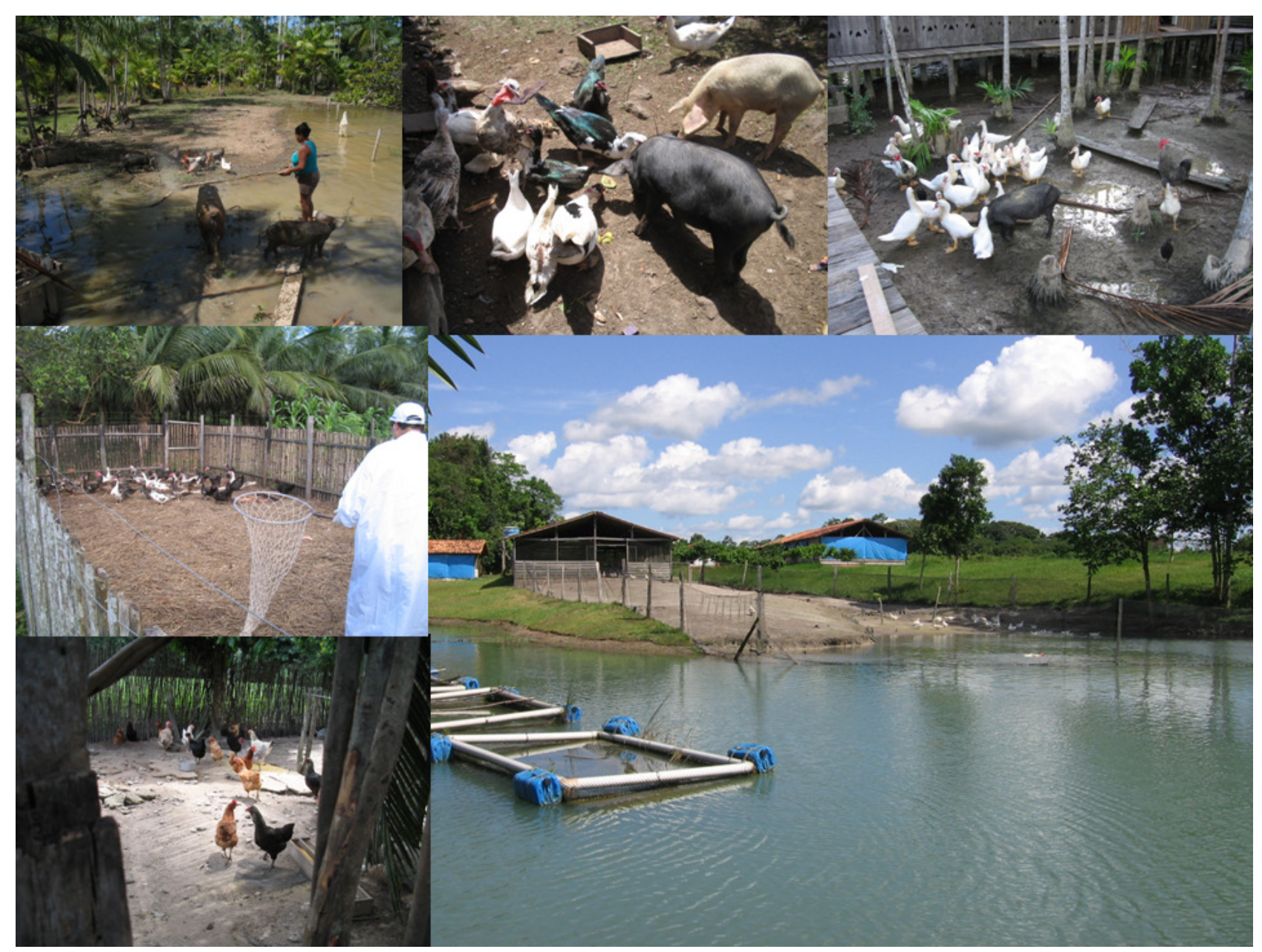

llustração 13- Panorama dos habitats e aves escolhidos para o estudo.

Para tal, após a escolha dos locais a serem estudados (definidos seguindo os critérios já mencionados), foi necessário um prévio contato com os proprietários, que após ciência dos procedimentos (aprovados pela Comissão de Ética em Experimentação Animal do Instituto de Ciências Biomédicas da Universidade de São Paulo) autorizavam a data e horário das respectivas coletas.

Por fim, desenvolvemos e seguimos protocolos que tentavam reduzir ao máximo o potencial de exposição tanto humana aos vírus, quanto dos próprios animais, com a prévia autorização do IBAMA. 


\subsection{Expedições Anuais}

Foram realizadas duas expedições principais à região Norte do país, região esta, considerada a principal porta de entrada de doenças exóticas aviárias, uma vez que a maioria das aves migratórias é proveniente da América do Norte. Foram utilizados dois veículos, adquiridos e equipados com o auxilio financeiro da FAPESP com o projeto Rede de Diversidade Genética Viral (VGDN - Processo 00/11511-6). Os veículos, um Land Rover Defender 110 e um Ford F-350, ambos com tração nas quatro rodas e equipados para trilhas off road (para possibilitar a coleta de amostras em regiões de difícil acesso), foram adaptados para laboratórios móveis, com todas as estruturas necessárias para se realizar as técnicas de captura, coleta de material e processamento laboratorial in situ (um barco, gerador, centrifuga, mesas, geladeira, botijão de nitrogênio líquido, redes, gaiolas, puçás, etc.)(Ilustração 14). 


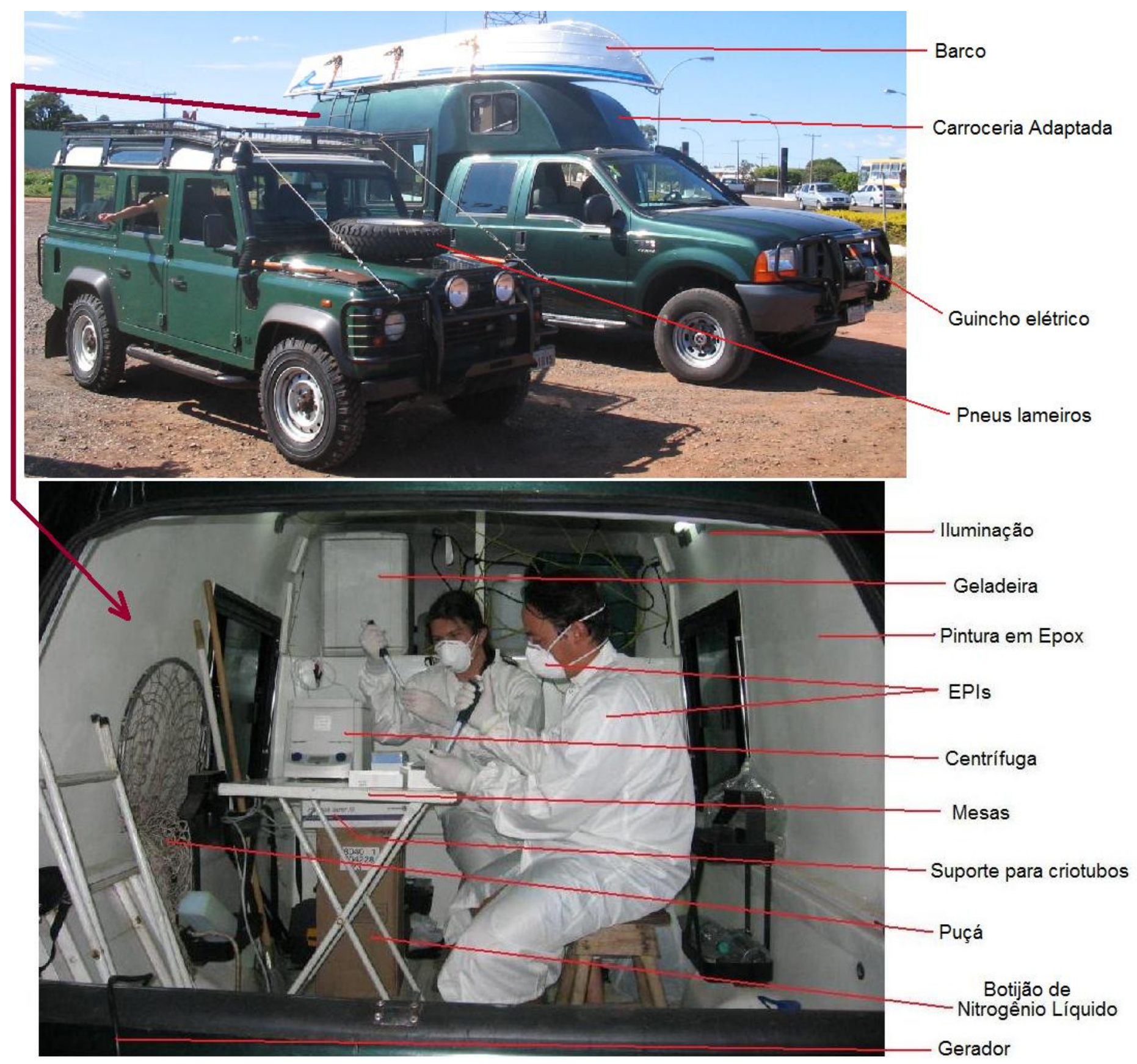

llustração 14- Foto dos veículos (Defender 110 e F-350) utilizados nas Expedições, mostrando os assessórios externos, necessários para os locais de difícil acesso, e as adaptações internas que transformaram um deles num laboratório móvel. 
A primeira expedição ocorreu em julho de 2005 na qual coletamos amostras de aves da região de Monte Negro em Rondônia e da região de Belém do Pará. Ao todo, percorremos $9.000 \mathrm{~km}$ e atravessamos 10 diferentes Estados brasileiros em 28 dias, sendo que coletamos amostras em dois Estados, o que resultou na captura de 38 passeriformes silvestres de diferentes espécies, 235 patos domésticos (Cairina mochata) e 28 galliformes (galinhas e perus), dos quais foram retiradas amostras de swabs cloacais e orais, e sangue.

A segunda expedição foi em julho de 2006 e durou 29 dias. Desta vez coletamos amostras de aves da região de Vigia de Nazaré e llha do Marajó, ambos no Pará. Coletamos amostras de 394 patos (domésticos e selvagens - Cairina mochata), 77 galinhas, 28 perus, 2 garças (Egreta thula e Euxenura maguarı) e uma gaivota.

Durante as expedições, além do caminhão (Ford F-350) que nos propiciava uma base para o processamento das amostras, criamos toda uma estrutura de coleta, totalmente desmontável e portátil. A cada dia, coletávamos amostras de aves em 3 a 5 propriedades diferentes e por isso tivemos cuidados redobrados com a biossegurança. Todos os integrantes da equipe utilizavam EPIs (Equipamentos de Proteção Individual, tais como, mascaras, luvas e aventais) no momento das coletas e durante o processamento do material coletado. Todo o lixo produzido era recolhido em saco plástico branco e trazido de volta para incineração; todas as pessoas e todo o material que entravam em contato com o ambiente de estudo eram descontaminados através do borrifamento de hipoclorito $0,5 \%$ antes de prosseguirmos para a próxima propriedade (Ilustração 15). 


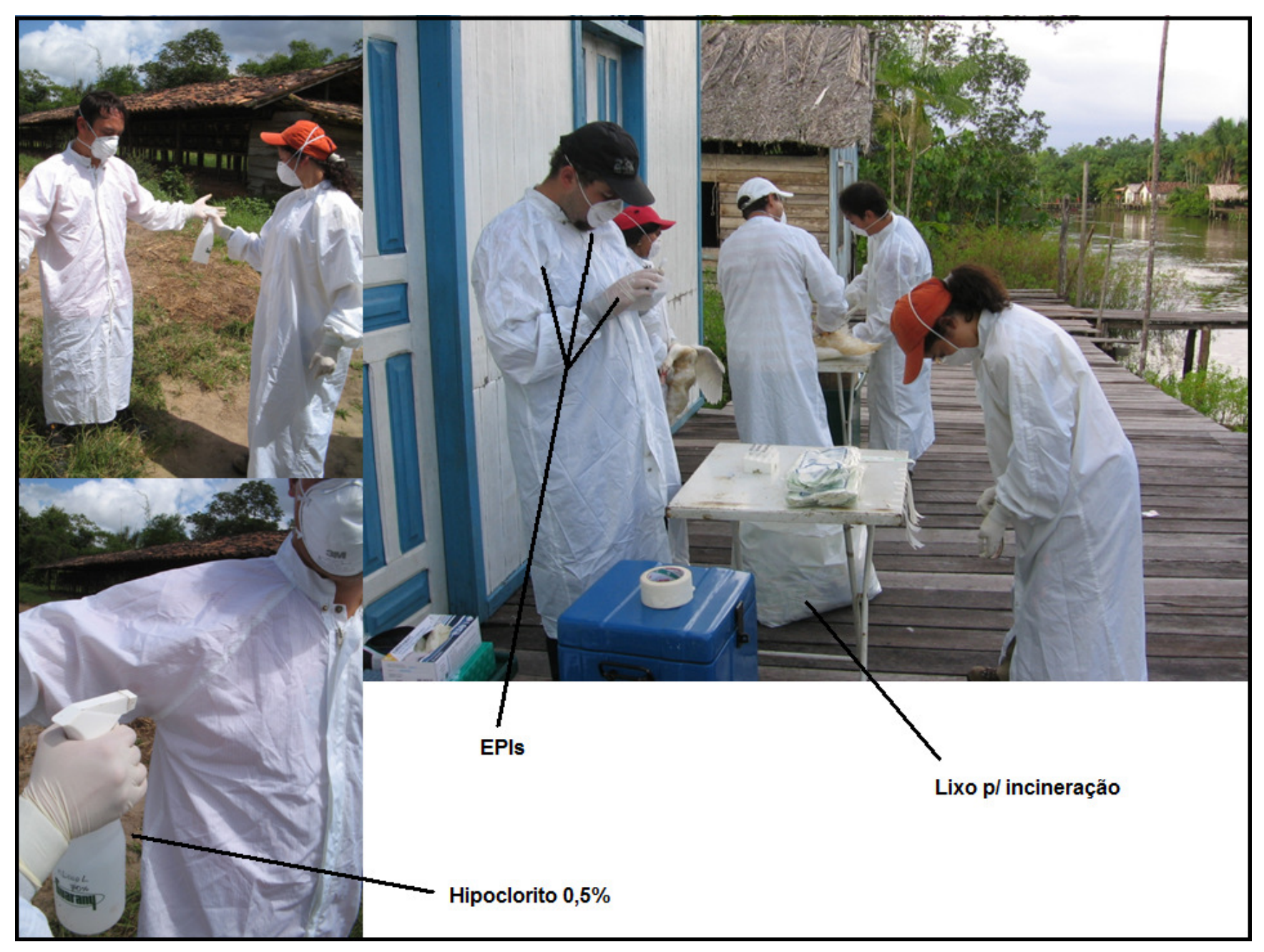

Ilustração 15- Foto dos equipamentos e cuidados com a biossegurança.

\subsection{Expedições Volantes}

Além das amostras coletadas nas Expedições Anuais (item 3.2), coletamos amostras de aves de diferentes regiões do Brasil em diferentes épocas do ano durante os anos de 2006 e 2007. Também demos preferência à locais de elevada confluência migratória, ou seja, locais que sabidamente eram um ponto de passagem das principais rotas migratórias aviárias (ver llustração 7) e que proporcionava assim, um ambiente propício para um maior contato entre as aves migratórias e as aves residentes (domésticas ou não), também estudadas. Foram expedições rápidas de no máximo três dias de duração, equipe reduzida e com prioridade em aves silvestres, migratórias ou não. 


\subsection{Expedição Antártica}

Em novembro de 2006, dois representantes da equipe de campo do Laboratório de Virologia Clínica e Molecular do Instituto de Ciências Biomédicas da Universidade de São Paulo (ICB-USP), Jansen de Araújo e Luis Sanfilippo, foram à Antártica em parceria com o projeto Proantar, para coletar amostras de pingüins ao redor da estação brasileira Comandante Ferraz, situada na península Keller, na Ilha Rei George (Ilustração 16).

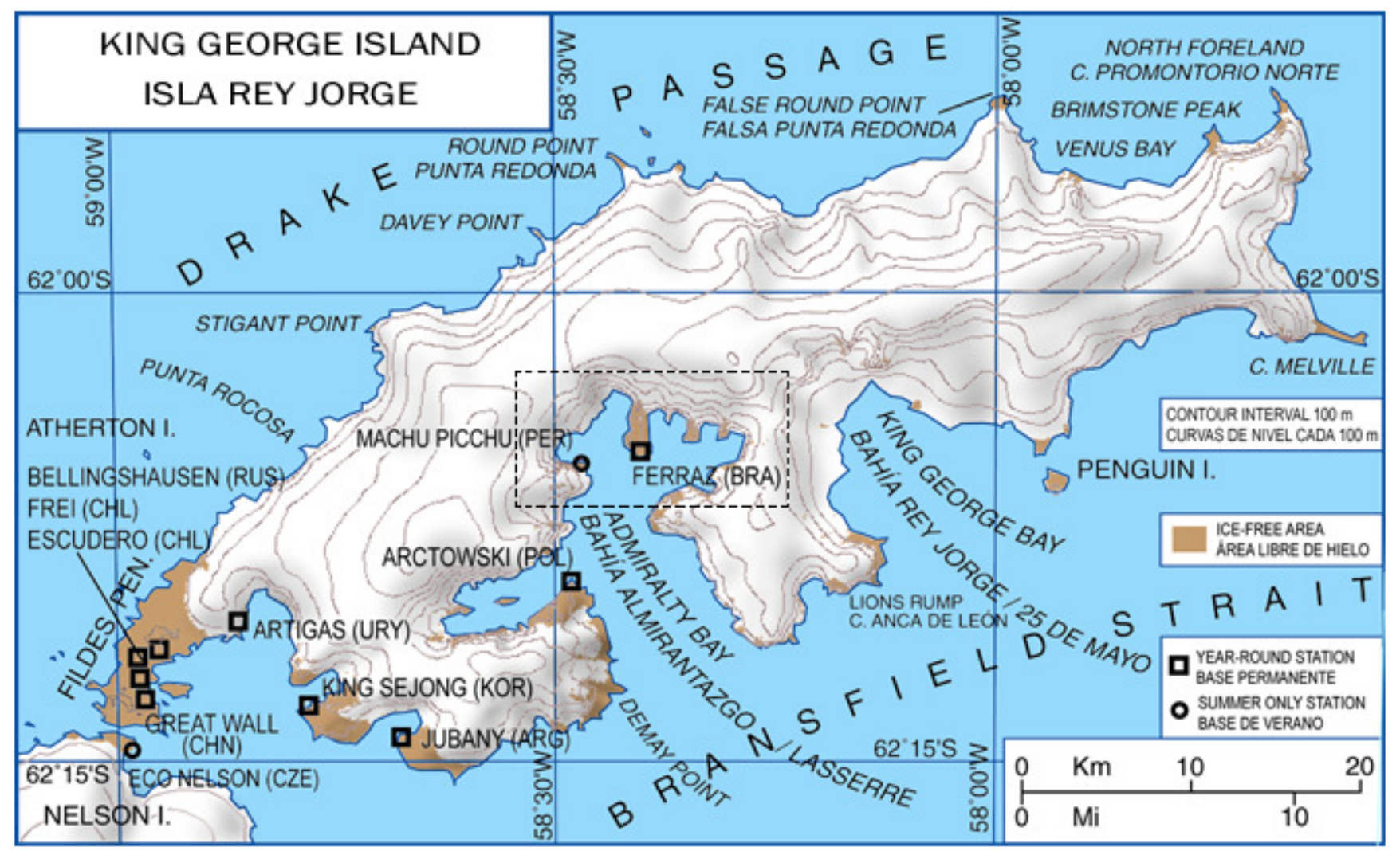

llustração 16- Mapa demonstrando a localização da estação brasileira e a região de coleta de amostras de pingüins em tracejado.

O número total de amostras, espécies amostradas, locais e datas de coletas, de todas as expedições juntas, podem ser observados na tabela a seguir (tabela 1). 
Tabela 1- Dados de todas as amostras utilizadas no projeto.

\begin{tabular}{|c|c|c|c|}
\hline Local & Data & $\begin{array}{l}\text { Espécies coletadas } \\
\text { (№ de indivíduos) }\end{array}$ & $\begin{array}{l}\text { Total de aves } \\
\text { amostradas }\end{array}$ \\
\hline Monte Negro - RO & Julho/2005 & $\begin{array}{l}\text { Passeriformes silvestres: } \\
\text { Myrmotherula hauxwelli (1) } \\
\text { Myrmotherula longipennis (1) } \\
\text { Myrmotherula nigrocinereus (2) } \\
\text { Mionectes macconneli (1) } \\
\text { Thamnophilus nigrocinereus (2) } \\
\text { Chiroxiphia pareola (1) } \\
\text { Momotus momota (1)*1 } \\
\text { Chiroxiphia ocellatus (1) } \\
\text { Phaethornis hispidus (3) } \\
\text { Ramphocelus carbo (5) } \\
\text { Formicivora grisea (3) } \\
\text { Thaminophilus aethiops (1) } \\
\text { Thryothorus genibarbis (2) } \\
\text { Cnemotricus fuscatus (1) } \\
\text { Tolmomyas poliocefalus (1) } \\
\text { Nyctidromus albicolis (1) }{ }^{2} \\
\text { Thamnophilus schistaceus (1) } \\
\text { Pipra fascicaudata (1) } \\
\text { Não identificado (2) }\end{array}$ & 31 \\
\hline Vigia/Marabitanas - PA & Julho/2005 & $\begin{array}{l}\text { Anseriformes domésticos: } \\
\text { Pato - Cairina moschata (235) } \\
\text { Galliformes: } \\
\text { Peru - Meliagres gallopavo (28) } \\
\text { Passeriformes silvestres: } \\
\text { Venilionis affinis (1)*3 } \\
\text { Tyraneutes stolzmanni (2) } \\
\text { Thamnophilus aethiops (2) } \\
\text { Thamnophilus nigrocinereus (1) } \\
\text { Passerina cyanoides (1) }\end{array}$ & 270 \\
\hline $\begin{array}{l}\text { Vigia/Marabitanas/São } \\
\text { Caetano de Odivelas; } \\
\text { São Sebastião da Boa } \\
\text { Vista, Ilha do Marajó - } \\
\text { PA }\end{array}$ & Julho/2006 & $\begin{array}{l}\text { Anseriformes: } \\
\text { Pato Doméstico- Cairina moschata } \\
\text { (386) } \\
\text { Pato Selvagem- Cairina moschata } \\
\text { (8) } \\
\text { Galliformes: } \\
\text { Galinha - Gallus gallus (77) } \\
\text { Peru - Meliagres gallopavo (28) } \\
\text { Ciconiiformes: } \\
\text { Garça - Egretta thula (1) } \\
\text { Maguari - Euxenura maguari (1) } \\
\text { Gaivota - Larus sp (1) }\end{array}$ & 502 \\
\hline $\begin{array}{c}\text { Breves, Ilha do Marajó - } \\
\text { PA }\end{array}$ & Outubro/2006 & $\begin{array}{l}\text { Anseriformes domésticos: } \\
\text { Pato - Cairina moschata (79) } \\
\text { Galliformes: } \\
\text { Galinha - Gallus gallus (6) }\end{array}$ & 85 \\
\hline (continua) & Novembro/2006 & $\begin{array}{l}\text { Charadriiformes: } \\
\text { Trinta réis - Sterna hirundo (7) } \\
\text { Maçarico - Calidris canutus (3) } \\
\text { Maçariquinho - Calidris pusilla (3) } \\
\text { Bate bunda - Actites macularia (15) } \\
\text { Anseriformes domésticos: } \\
\text { Pato - Cairina moschata (8) }\end{array}$ & 36 \\
\hline
\end{tabular}

* Não são passeriformes; 1-Coraciiforme, 2-Strigiforme, 3-Piciforme. 
Tabela 1. (continuação)

\begin{tabular}{|c|c|c|c|}
\hline Local & Data & $\begin{array}{l}\text { Espécies coletadas } \\
\text { (№ de indivíduos) }\end{array}$ & $\begin{array}{l}\text { Total de aves } \\
\text { amostradas }\end{array}$ \\
\hline $\begin{array}{l}\text { Araranguá/Tijuca/ } \\
\text { Barra Velha/ } \\
\text { Navegantes - SC }\end{array}$ & Novembro/2006 & $\begin{array}{l}\text { Anseriformes: } \\
\text { Pato Doméstico- Cairina moschata } \\
\text { (12) } \\
\text { Ganso - Anser sp (8) } \\
\text { Marreco - Anas sp (7) } \\
\text { Galliformes: } \\
\text { Galinha - Gallus gallus (10) } \\
\text { Galinha D'angola - Numida meliagres } \\
\text { (2) } \\
\text { Peru - Meliagres gallopavo (6) } \\
\text { Charadriiformes: } \\
\text { Maçarico - Tringa melanoleuca (1) } \\
\text { Talha mar - Rynchops niger (3) } \\
\text { Quero-quero - Vanellus chilensis (1) }\end{array}$ & 50 \\
\hline $\begin{array}{c}\text { São Bento/ Cajapió - } \\
\text { MA }\end{array}$ & Abril/2007 & $\begin{array}{l}\text { Galliformes: } \\
\text { Peru - Meliagres gallopavo (1) } \\
\text { Anseriformes: } \\
\text { Marreco - Dendrocygna Viduata (18) } \\
\text { Marreco - Dendrocygna autumnalis } \\
\text { (44) } \\
\text { Marreco - Netta Erythrophthalma (2) } \\
\text { Marreco - Gallinula chloropus (2) } \\
\text { Marreco - Amazonetta brasiliensis (4) } \\
\text { Marreco - Anas sp (3) }\end{array}$ & 74 \\
\hline $\begin{array}{l}\text { Coroa do Avião, Ilha de } \\
\text { Itamaracá - PE }\end{array}$ & Abril/2007 & $\begin{array}{l}\text { Charadriiformes: } \\
\text { Maçarico - Arenaria interpres (6) } \\
\text { Maçarico - Calidris alba (10) } \\
\text { Maçarico - Calidris pusilla (5) } \\
\text { Maçarico - Charadrius } \\
\text { semipalmatus (3) }\end{array}$ & 24 \\
\hline $\begin{array}{l}\text { Península Keller- } \\
\text { ANTÁRTICA }\end{array}$ & Novembro/2006 & $\begin{array}{l}\text { Sphenisciformes: } \\
\text { Pingüins - Pygoscelis antarcticus } \\
\text { Pingüins - Pygoscelis adeliae } \\
\text { Pingüins - Pygoscelis papua }\end{array}$ & 100 \\
\hline
\end{tabular}

TOTAL 


\subsection{Armadilhamento}

Para a captura de aves passeriformes silvestres foram utilizadas redes de neblina estrategicamente armadas no interior de áreas florestais preservadas e/ou corredores descampados de bordas de mata. As redes foram montadas em varas de bambus dispostas em série numa altura de cerca de $30 \mathrm{~cm}$ do solo até $250 \mathrm{~cm}$ de altura. As aves domésticas de granjas e aves domésticas ou selvagens ${ }^{2}$ de "fundo de quintal", bem como os pingüins, foram capturadas com o auxilio de puçás (llustração 17).

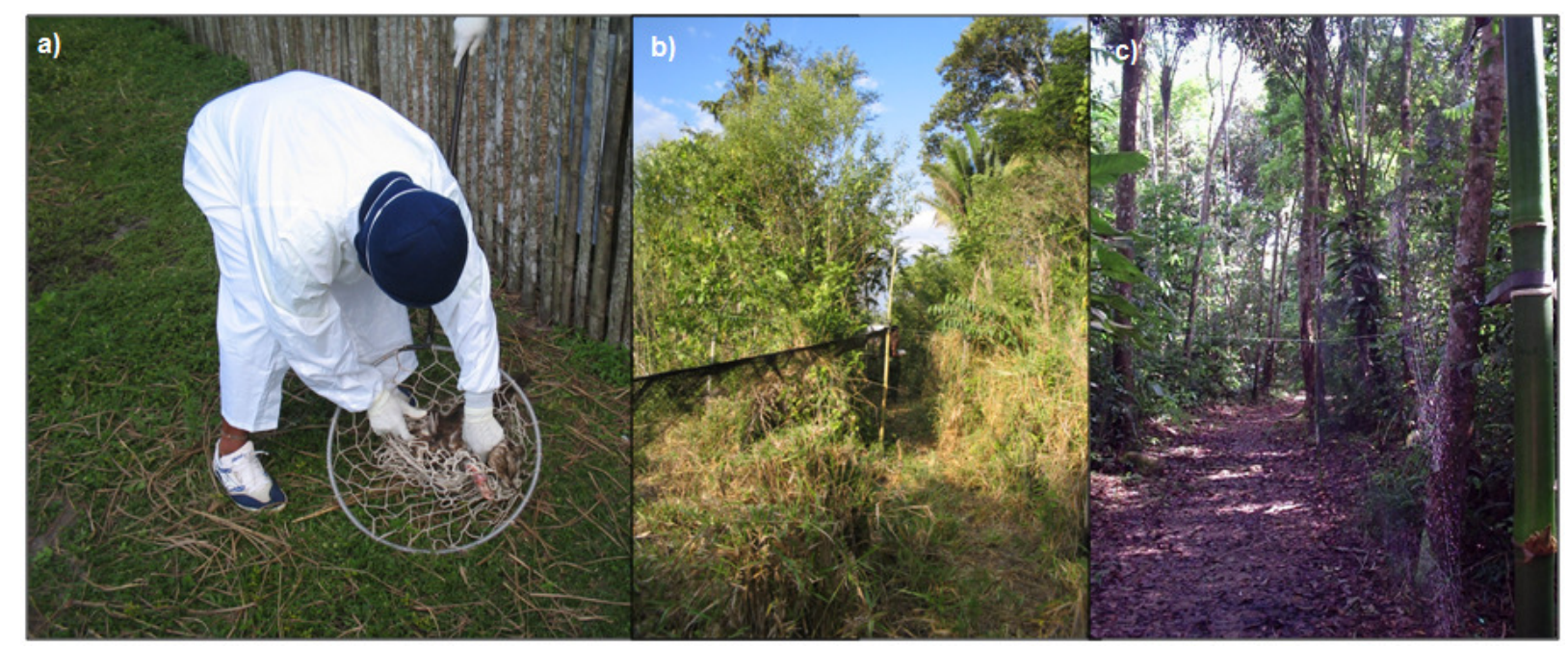

llustração 17- Métodos utilizados para a captura das aves estudadas: a) puçá; b) e c) redes de neblina (fechada e aberta, respectivamente).

\subsection{Triagem e identificação}

O processo de identificação e biometria requer certo conhecimento ornitológico e habilidade no caso das aves silvestres, assim os especialistas do grupo realizavam o trabalho de medição e tabulação das informações em planilhas para análise posterior, se necessário. As planilhas continham dados biológicos de status (ave nova, recaptura, recuperação), idade (adulto, jovem, ninhego,

\footnotetext{
${ }^{2} \mathrm{Na}$ região Norte/Nordeste do país é comum as populações ribeirinhas criarem aves selvagens junto com as domésticas, sem distinção, e por isso também entraram no estudo.
} 
indeterminado), identificação (espécie, ordem), sexo (macho, fêmea, indeterminado), método (plumagem, cloaca, cor dos olhos, outros), plumagem (jovem $1^{\circ}$ ano, subadulto, adulto) além das medidas da asa, tarso, cauda, cúmen total, narina-ponta e peso. A necessidade de conhecimento das informações acima se dá como um fator fundamental para conhecimento da fauna e do entendimento do fator de risco de disseminação de doenças que esses animais podem ser para outros animais e pessoas. O processo de anilhamento não foi realizado, entretanto as aves capturadas eram marcadas com violeta diluída em água, no momento da soltura para que em caso de recaptura fossem facilmente identificadas. Por fim, a coleta de informações teve como objetivo conhecer melhor as espécies capturadas: auxiliar na determinação da quantidade de sangue a ser coletada; além de definir em que fase de desenvolvimento estes animais se encontravam.

\subsection{Coleta do material}

As amostras de todas as aves capturadas foram colhidas através da introdução e raspagem epitelial de zaragatoas estéreis descartáveis na traquéia (swab oral) e cloaca (swab cloacal) do animal (Ilustração 18A,B). Os swabs orais e cloacais foram colocados no mesmo tubo, em três réplicas, duas contendo meio de congelamento (meio de cultura MEM - Cutilab; pH 7,2; esterilizada; glicerol 5\%; contendo $100 \mathrm{U} / \mathrm{mL}$ de penicilina e $100 \mu \mathrm{g} / \mathrm{mL}$ estreptomicina) e uma contendo Brazol (LGCBio). Os tubos foram imediatamente armazenados em nitrogênio líquido (Ilustração 18C). Foi coletado, também, aproximadamente $1 \mathrm{~mL}$ de sangue através de punção da veia ulnar de uma das asas de cada ave estudada ou dos membros inferiores no caso dos pingüins, em seringas descartáveis estéreis de $3 \mathrm{~mL}$ (Ilustração 18D). O soro foi obtido in situ, após repouso de 4 horas, através da centrifugação do sangue a $3000 \mathrm{~g}$ por 10 minutos, em até 24 horas. O soro e o coágulo foram também estocados em nitrogênio líquido após separação. As amostras foram mantidas congeladas em nitrogênio líquido durante todo o trajeto das expedições. 


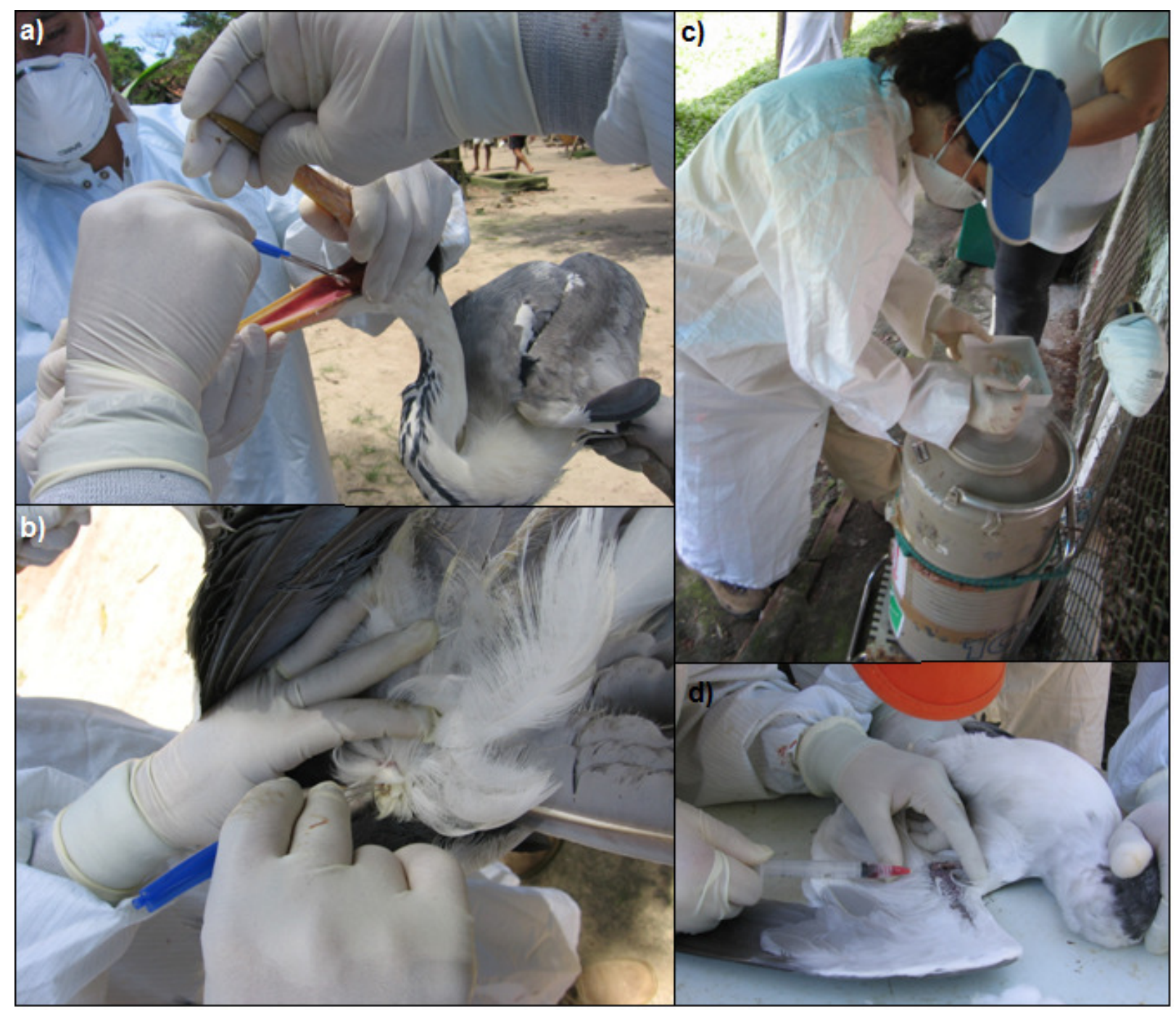

llustração 18- Métodos utilizados na coleta do material das aves estudadas: A) swab oral; B) swab cloacal; C) congelamento em nitrogênio líquido; D) punção da veia ulnar.

\subsection{Extração do RNA total}

As extrações de RNA foram feitas no laboratório NB-3 (Laboratório de Biossegurança Nível 3) do Instituto de Ciências Biomédicas da USP, utilizando o tubo de amostras em Brazol (LGCBio) e seguindo suas instruções. Ao tubo de amostras clinicas que previamente continha o Brazol, foi adicionado $10 \%$ de clorofórmio (Merck), homogeneizado em vortex e incubado em banho de gelo por 5 minutos. Foi centrifugado a $15000 x$ durante 15 minutos a $4{ }^{\circ} \mathrm{C}$. A seguir, o sobrenadante foi transferido para outro microtubo, contendo isopropanol (Sigma) volume a volume, homogeneizado, incubado por 15 minutos em gelo e centrifugado a $15000 x$ durante 15 minutos a $4^{\circ} \mathrm{C}$. O sobrenadante foi desprezado e ao restante 
foi acrescentado $800 \mu \mathrm{L}$ de etanol 75\% (Merck) seguindo-se de uma centrifugação a 10000xg durante 8 minutos a $4{ }^{\circ} \mathrm{C}$. O sobrenadante foi novamente desprezado e 0 sedimento, após secagem, ressuspendido em $50 \mu \mathrm{L}$ de água livre de DNA/RNAse (Gibco). O produto foi imediatamente levado à próxima etapa (item 3.9).

\subsection{Transcrição Reversa}

Para a obtenção do cDNA foi utilizado o kit Hight Capacity cDNA Archive seguindo as orientações do fabricante (Appied Biosystems), no qual, $50 \mu \mathrm{L}$ de RNA extraído foram diluídos em tampão contendo 50 pMoles de Random primers e demais reagentes obtendo-se um tampão de reação $50 \mathrm{mM}$ de $\mathrm{Tris}-\mathrm{HCl}[\mathrm{pH} 8.3$ a 25 $\left.{ }^{\circ} \mathrm{C}\right]$ / $75 \mathrm{mM}$ de $\mathrm{KCl} / 3 \mathrm{mM}$ de $\mathrm{MgCl}_{2}$ (10x RT Buffer), $10 \mathrm{mM}$ de Dithiothreitol, $50 \mathrm{U}$ de MultiScribe RT enzyme, $02 \mathrm{U}$ de Inibidor de Ribonuclease, $1.5 \mathrm{mM}$ de dNTP e água UltraPure (Gibco) q.s.p. $100 \mu \mathrm{L}$. A mistura foi incubada a $25^{\circ} \mathrm{C}$ por 10 minutos e $37^{\circ} \mathrm{C}$ por 120 minutos no termociclador GeneAmp PCR System 9700 (Applied Biosystems). O cDNA foi armazenado em freezer $-70{ }^{\circ} \mathrm{C}$ até o momento de sua amplificação.

\subsection{Primers}

Os oligonucleotídeos iniciadores (primers) e a sonda utilizados foram desenhados por Wise (2004), a partir do alinhamento pelo método de ClustalW de 30 isolados de NDV de diferentes regiões do mundo e desenhados com o programa Primer3. Um primeiro conjunto de primers e sonda, selecionados de uma região conservada do gene $\mathrm{M}$ (matriz), foi projetado para amplificar praticamente todos os isolados de NDV conhecidos. Um segundo conjunto de primers e sonda foi selecionado para detectar especificamente apenas os isolados meso e velogênicos, os primers flanqueiam o sítio de clivagem da fusão (gene F - fusão) e a sonda do tipo hidrolítica se anela diretamente a ele. A lista completa dos isolados utilizados para projetar os conjuntos de primers e seus respectivos espectros de detecção, pode ser visualizada na Tabela 2. 
Tabela 2. Espectro de detecção dos conjuntos de primers-sonda selecionados.

\begin{tabular}{|c|c|c|c|}
\hline \multirow[b]{2}{*}{ Isolados } & \multirow[b]{2}{*}{ Patótipo* } & \multicolumn{2}{|c|}{$\begin{array}{l}\text { Especificidade do conj. Primers-sonda } \\
\text { (gene alvo) }\end{array}$} \\
\hline & & $\begin{array}{l}\text { APMV-1 } \\
\text { (Matriz) }\end{array}$ & $\begin{array}{c}\text { Velo-mesogênico } \\
\text { (Fusão) }\end{array}$ \\
\hline Chicken/US/B1/48 & L & + & - \\
\hline Chicken/US/LaSota/46 & L & + & - \\
\hline Chicken/Northen Ireland/Ulster/64 & $\mathrm{L}$ & + & - \\
\hline Chicken/Australia/QV4/66 & L & + & - \\
\hline Turkey/US/VGGA/87 & L & + & - \\
\hline Chicken/US(Nebraska)/54 & L & + & - \\
\hline Chicken/US/23984/96 & $\mathrm{L}$ & + & - \\
\hline Chicken/US/Kimber/47 & M & + & + \\
\hline Chicken/US/Roakin/48 & M & + & + \\
\hline Chicken/US(Texas)/DK1155/59 & M & + & + \\
\hline Chicken/US(Michigan)/46967/46 & M & + & + \\
\hline Chicken/US (Mass.)/MK107/45 & M & + & + \\
\hline Anhinga/US/44083/93 & M & + & + \\
\hline Mixed species/US/Largo/71 & $\mathrm{V}$ & + & + \\
\hline Chicken/US/BeaudetteC/52 & V & + & + \\
\hline Chicken/US(Texas)/GB/48 & V & + & + \\
\hline Chicken/UK/Herts/33 & V & + & + \\
\hline Chicken/Australia/Victoria/11176/32 & V & + & + \\
\hline Cockatiel/US(Florida)/FL/80 & V & + & + \\
\hline Cormorant/US(Minn.)/40068/92 & V & + & + \\
\hline Turkey/US(N. Dak.)/43084/92 & V & + & + \\
\hline Cockatoo/Indonesia/14698/90 _ _ & V & + & + \\
\hline Parakeet/Tanz,Belg,China/28710/93 & V & + & + \\
\hline Pigeon/US(Ga.)/21042/98 & $\mathrm{V}$ & + & + \\
\hline Chicken/Italy/3286/00 & V & + & + \\
\hline Dove/Italy/2736/00 & V & + & + \\
\hline Pigeon/ltaly/1166/00 & V & + & + \\
\hline Chicken/US/CA1083(Fontana)/72 & V & + & + \\
\hline Game chicken/US(Ca.)/24255/98 & $\mathrm{V}$ & + & + \\
\hline Parakeet/Myanmar/11592/91 & V & + & + \\
\hline Chicken/Honduras/44813/00 & V & + & + \\
\hline Pigeon/US(Tex.)/17498/98 & V & + & + \\
\hline Chicken/Mexico/37821-550-2/96 & $\mathrm{V}$ & + & + \\
\hline Pheasant/US(Ca.)/F98-1208/98 & V & + & + \\
\hline Pigeon/CA/1307/75 & V & + & + \\
\hline Chicken/Kenya/KRC139/90 & $\mathrm{V}$ & + & + \\
\hline Pigeon/US(N.Y.)/84 & $\mathrm{V}$ & + & + \\
\hline Game chicken/US(CA)/211472/02 & $\mathrm{V}$ & + & + \\
\hline APMV-2/chicken/CA/Yucaipa/56 & NA & - & - \\
\hline APMV-3/turkey/Wisconsin/68 & NA & - & - \\
\hline APMV-4/duck/Hong Kong/D3/75 & NA & - & - \\
\hline APMV-7/dove/Tennesse/4/75 & NA & - & - \\
\hline
\end{tabular}

*L, lentogênico; M, mesogênico; V, velogênico. NA, não se aplica. 
$O$ conjunto de primers desenhado para 0 gene $M$ de matriz amplifica um fragmento de aproximadamente 120 pares de bases. As seqüências dos primers e da sonda foram: primer positivo M+4100 (5'-AGT GAT GTG CTC GGA CCT TC-3'), primer negativo M-4220 (5'-CCT GAG GAG AGG CAT TTG CTA-3') e a sonda M4169 (5'-[FAM] TTC TCT AGC AGT GGG ACA GCC TGC [MGB]). (Entre colchete representa o marcador fluorescente utilizado).

$O$ conjunto de primers desenhado para o gene $F$ de fusão amplifica um fragmento de aproximadamente 110 pares de bases e suas seqüências foram: primer positivo F+4829 (5' GGT GAG TCT ATC CGG ARG ATA CAA G 3'), primer negativo F-4939 (5' AGC TGT TGC AAC CCC AAG 3') e sonda F+4894 (5' FAMAAG CGT TTC TGT CTC CTT CCT CCA-MGB 3'). A região de pareamento de cada conjunto de primers e sondas, pode ser observada na llustração 19.
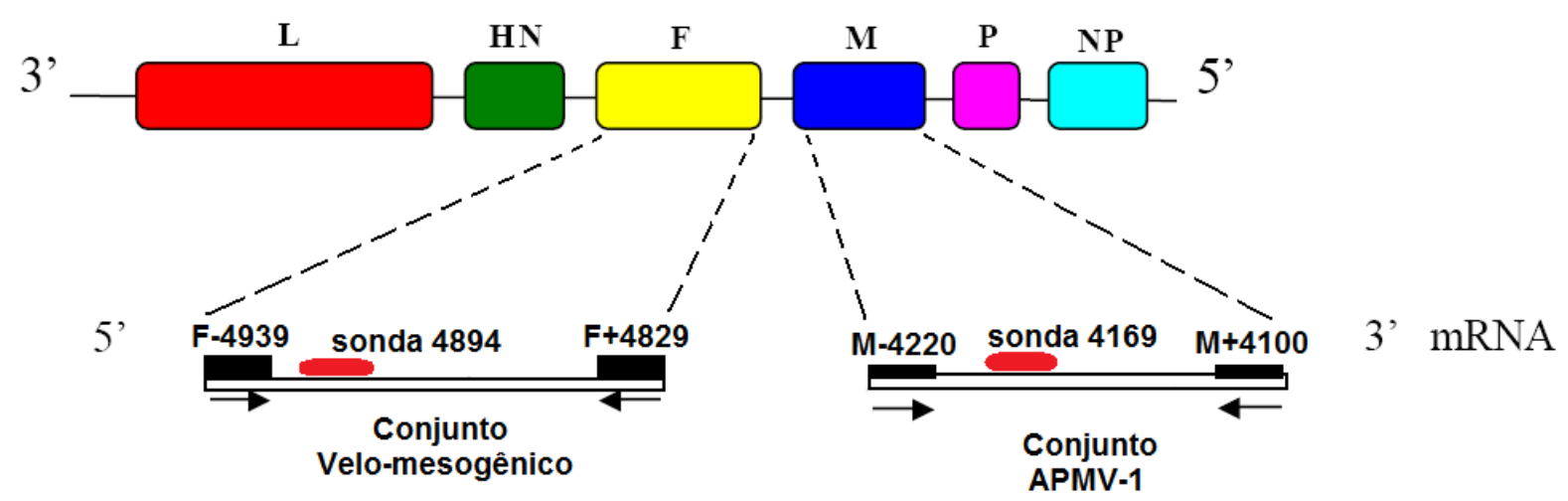

llustração 19- Esquema de pareamento dos conjuntos de primers-sonda selecionados ao genoma do NDV.

\subsection{Reação em Cadeia da Polimerase em Tempo Real (qPCR)}

A amplificação em tempo real foi efetuada em placa de PCR de 96 orifícios (Applied Biosystems), na qual $3 \mu \mathrm{L}$ de cDNA foi diluído em tampão $20 \mathrm{mM}$ de Tris$\mathrm{HCl}$ [pH 8.4] / $50 \mathrm{mM}$ de $\mathrm{KCl} / 2 \mathrm{mM}$ de $\mathrm{MgCl}_{2}$ (Biotools), 10 pMoles de cada primer $(M+4100$ e M-4220), 10 pMoles da sonda M4169, $1 \mathrm{U}$ de Taq DNA Polimerase (Biotools), $0.2 \mathrm{mM}$ de cada dNTP e água UltraPure q.s.p. $25 \mu \mathrm{L}$. As placas foram amplificadas no termociclador Real Time 3300 PCR System (Applied Biosystems). A amplificação foi efetuada a partir de uma etapa de desnaturação de $94{ }^{\circ} \mathrm{C}$ por 2 minutos, seguida de 40 ciclos de $94{ }^{\circ} \mathrm{C}$ por 15 segundos, para desnaturação das 
fitas de DNA; $56{ }^{\circ} \mathrm{C}$ por 30 segundos, para o pareamento dos primers (fase no qual, foram coletados os dados de fluorescência); e $72{ }^{\circ} \mathrm{C}$ por 15 segundos, para a extensão das fitas de DNA. Como controle positivo foi incluído uma amostra de cultura, em ovo embrionado de galinha, de cepa vacinal (B1 - Fort Dodge) e como controle negativo foi utilizada água livre de DNA/RNAse esterilizada (Gibco).

As amostras positivas pela reação acima, foram submetidas a uma nova reação de qPCR com as mesmas condições de reagentes, porém com primers desenhados para anelarem na região do gene $F$ de Fusão com o objetivo de amplificar apenas amostras contendo cepas mesogênicas ou velogênicas. Os parâmetros de amplificação possuíam os mesmos ciclos de temperatura do gene de matriz com a diferença que a temperatura ótima de pareamento dos primers foi de $58^{\circ} \mathrm{C}$. Neste caso, o controle positivo foi uma amostra de RNA extraído da cepa São João de Meriti (gentilmente cedida pelo Dr. Adriano Carrasco da Universidade Estadual do Centro-Oeste, Departamento de Medicina Veterinária - DEVET.) e como controle negativo foi utilizada água livre de DNA/RNAse esterilizada (Gibco).

\subsection{Isolamento}

As amostras cloacais/traqueais em meio de congelamento, correspondentes às amostras que foram diagnosticadas positivas por qPCR, foram inoculadas em ovos embrionados de galinha SPF (livre de patógenos específicos), gentilmente cedidos pela empresa BIOVET ${ }^{\circledR}$, Cotia - São Paulo, para a replicação viral. As amostras foram centrifugadas a $3000 x g$ por 30 minutos e o líquido claro superior foi coletado e filtrado em filtro de membrana de 0,22 $\mu \mathrm{m} .0,2 \mathrm{~mL}$ do filtrado diluído $2 x$ em PBS esterilizado, pH 7,2 foi inoculado na cavidade alantóica de ovos embrionados de 10 dias de idade. Cada amostra foi inoculada em 3 ovos e depois de 72 horas de incubação à $37{ }^{\circ} \mathrm{C}$, os ovos foram resfriados em freezer $-20{ }^{\circ} \mathrm{C}$ por 15 minutos e seus fluídos alantóicos recolhidos. Em seguida, este material foi testado para a presença viral pelo teste de hemaglutinação (HA) e por qPCR, e o excedente foi armazenado em freezer $-70{ }^{\circ} \mathrm{C}$. Qualquer fluído que demonstrasse a presença de atividade hemaglutinante foi testado pela Inibição da Hemaglutinação (HI), para a presença do NDV usando anticorpo padrão preparado contra a cepa B1. 
O valor do título de HA foi expresso como a recíproca da maior diluição do fluido alantóico no qual houve atividade hemaglutinante.

\subsection{Hemaglutinação e Inibição da Hemaglutinação (HA e HI)}

O teste de HA foi realizado em microplacas de 96 cavidades com fundo em "U” (Biosystems). Para tanto, diluições 1/10 seriadas na base dois, em solução salina tamponada fosfatada a 0,01 M; pH 7,2; esterilizada (PBS), dos fluídos alantóicos colhidos foram colocados nas cavidades da placa, nas quais se adicionou uma suspensão de eritrócitos lavados de galinha a 0,5\% em PBS (lavada e centrifugada $1000 \mathrm{~g} / 10 \mathrm{~min}$ por três vezes) e incubou-se por 30 minutos, à temperatura ambiente. O título foi definido como o inverso da maior diluição de líquido alantóico capaz de apresentar atividade hemaglutinante.

A prova de $\mathrm{HI}$ foi realizada em microplacas de 96 cavidades com fundo em "U". Para tanto, diluições seriadas na base dois em PBS dos soros previamente tratados com RDE (Receptor-Destroyer Enzime gentilmente cedido pelo Dr. Robert G. Webster, St. Jude Children's Research Hospital, Memphis, Tennessee, USA) na proporção 1/3/6 (amostra/RDE/Solução salina 0,85\% $\mathrm{NaCl}$ ), foram colocadas nas cavidades da placa, nas quais adicionou-se o antígeno viral padronizado (cepa B1 New vacB1® Fort Dodge) com quatro unidades hemaglutinantes (UHA) e incubou-se por 30 minutos, à temperatura ambiente. Superada esta etapa, uma suspensão de eritrócitos lavados de galinha a $0,5 \%$ em PBS foi adicionada às cavidades como sistema revelador da reação e incubou-se por mais 30 minutos, à temperatura ambiente. O título foi definido como o inverso da maior diluição de soro capaz de inibir completamente a atividade hemaglutinante viral (Alexander, 1989).

\subsection{4 Índice de Patogenicidade: Tempo Médio de Morte de Embriões (TME)}

Diluições decimais em solução salina de $10^{-3}$ do líquido alantóico das amostras isoladas em ovos embrionados no item anterior, foram re-inoculadas $(0,1$ $\mathrm{mL}$ ) em 5 ovos SPF de 8-10 dias e incubados a $37^{\circ} \mathrm{C}$, para determinar o tempo médio, em horas, que a dose letal mínima (maior diluição capaz de matar todos os embriões) levou para matar os embriões. Os ovos foram observados duas vezes ao 
dia, durante sete dias e o tempo de morte dos embriões registrados, para o calculo do TME. De acordo com a OIE, o TME se classifica em: 1) Velogênica - menos de 60 horas para matar; 2) Mesogênica - entre 60 e 90 horas para matar; 3) Lentogênica - mais de 90 horas para matar.

\subsection{Prevenção de contaminação e biossegurança}

Para reduzir a possibilidade de contaminação das amostras e dos reagentes separamos o pré, o durante e o pós-ensaios em três salas diferentes, cada qual com seus próprios equipamentos, reagentes, instrumentos e descartáveis (luvas, pró-pés, aventais e ponteiras com filtro). Trocamos de luvas regularmente, pré distribuímos os reagentes em alíquotas e usamos múltiplos controles (positivos e negativos) em cada lote de amostras testadas. Como controle positivo foi utilizada a cepa vacinal B1 (New vac-B1® Fort Dodge) e como controle negativo foi adicionada água livre de DNA/RNAse. Todas as áreas e equipamentos foram descontaminados com hipoclorito de sódio $2 \%$ ou álcool $78 \%$ antes e depois de cada ensaio. Além disso, a análise pelo método de qPCR reduziu ainda mais o risco de contaminação ao permitir a sensível detecção dos produtos amplificados, sem a necessidade de abrir os tubos. Por fim, todas as etapas nas quais fossem manipuladas amostras contendo vírus ativos (extração, isolamento e ensaios biológicos) foram realizadas dentro do laboratório de biossegurança nível 3 do Instituto de Ciências Biomédicas da Universidade de São Paulo.

\subsection{Otimização e teste das reações}

A padronização da qPCR foi feita de acordo com o item 3.11, fazendo-se alterações principalmente na concentração de $\mathrm{MgCl}$, na duração dos ciclos de amplificação, e nas temperaturas de pareamento e extensão. Não houve alterações significativas em relação ao protocolo original descrito na literatura (Wise, 2004). Os primers utilizados na padronização foram gentilmente cedidos pela Dra. Liana Brentano da Empresa brasileira de pesquisas agropecuárias (EMBRAPA) de Santa Catarina, bem como os RNAs extraídos de amostras padrões (Ulster, La Sota e São 
João de Meriti), pelo Dr. Adriano Carrasco da Faculdade de Ciências Agrárias e Veterinárias da Universidade Estadual Paulista Júlio de Mesquita Filho, de Jaboticabal. Depois da padronização das reações de qPCR, mandamos sintetizar os primers pela Applied Biosystems que teve como única alteração, a substituição de um dos marcadores fluorescentes das sondas (3'), de $\mathrm{BHQ}^{\circledR}$ (Biosearch) para $M B^{T M}$ ( Applied biosystems).

Com os novos primers, fizemos testes de especificidade/sensibilidade a fim de verificarmos não apenas os limites de detecção, bem como se cada conjunto de primers cumpria o esperado, ou seja, se os primers de matriz detectavam todas as cepas de NDV e se os primers de fusão detectavam apenas as amostras velogênicas. Para isso, fizemos testes de diluições seriadas de RNAs de amostras padrões e testes utilizando diferentes tipos de amostras clínicas de nossa biblioteca de cDNAs.

Para a padronização do isolamento em ovo embrionado (item 3.12), foram utilizadas cepas vacinais de vírus vivos atenuados da linhagem Ulster cepa $2 \mathrm{C}$ (Poulvac NDW® Fort Dodge) e da linhagem B1 cepa B1 (New vac-B1® Fort Dodge). Estas mesmas cepas isoladas foram utilizadas como controle positivo em todos os ensaios (item 3.8 ao item 3.13).

\subsection{Sequenciamento do material genético}

Os produtos da qPCR das amostras positivas, bem como os isolados em ovos de galinha, foram purificados e posteriormente seqüenciados. Para a purificação foi utilizado o método de precipitação por isopropanol, no qual $50 \mu \mathrm{L}$ do produto amplificado foi adicionado a um microtubo contendo $300 \mu \mathrm{L}$ de isopropanol $75 \%$, centrifugado a 12000xg por 20 minutos à temperatura ambiente e o sobrenadante foi descartado. Houve mais uma lavagem com $200 \mu \mathrm{L}$ de etanol $75 \%$, seguido de uma ultima centrifugação de $8000 x g$ por 8 minutos, o sobrenadante descartado e o precipitado ressuspendido em $50 \mu \mathrm{L}$ de água livre de DNA/RNAse (Gibco). Para a reação de sequenciamento do DNA, foi utilizado o BigDye Terminator Cycle Sequencing Ready Reaction Kit - Ampli Taq DNA Polymerase (Applied Biosystems), no qual $2 \mu \mathrm{L}$ de tampão de sequenciamento (save money-5X), $2 \mu \mathrm{L}$ de reagente de seqüenciamento (Kit-BigDye Terminator), $3 \mu \mathrm{L}$ do primer $(1 \mathrm{p} / \mathrm{mol}), 1 \mu \mathrm{L}$ de água 
estéril e $2 \mu \mathrm{L}$ do produto de qPCR purificado, totalizando um volume final de $10 \mu \mathrm{L}$, foram submetidos ao ciclo de sequenciamento, no termociclador Eppendorf 2500: 96 ${ }^{\circ} \mathrm{C}$ por 1 minuto, seguido de 25 ciclos de $94{ }^{\circ} \mathrm{C}$ por 45 segundos, $50{ }^{\circ} \mathrm{C}$ por 54 segundos e $72{ }^{\circ} \mathrm{C}$ por 2 minutos. $\mathrm{O}$ sequenciamento foi realizado nos dois sentidos, ou seja, utilizando-se os dois primers e em triplicatas, a fim de identificar possíveis erros de leitura das bases. A detecção dos nucleotídeos marcados por fluorescência foi realizado no seqüenciador automático de DNA ABI PRISM 3100 (Applied Biosystems).

\subsection{Alinhamento e filogenia}

A busca inicial de similaridade das seqüências obtidas com outras disponíveis no GenBank da página do NCBI (National Center for Biotechnology Information no endereço eletrônico: http://www.ncbi.nlm.nih.gov) foi realizada pelo programa BLAST versão 2.0, disponível no mesmo endereço. No alinhamento, foram inclusos os vírus descritos na tabela 3, que mostra os respectivos números de acesso no GenBank. Alinhamentos para as seqüências deduzidas de aminoácidos também foram igualmente realizados. Matrizes de distâncias dadas em porcentagens de similaridade entre as sequências nucleotídicas obtidas foram calculadas através do programa MegAlign $^{\text {TM }}$ versão 5.03 (DNAStar()). O alinhamento e a edição das seqüências nucleotídicas foi realizado com o programa Bioedit Sequence Alignment Editor versão 6.0.7 (programa gratuito disponível no endereço http://www.mbio.ncsu.edu/BioEdit/), que converteu os arquivos ao formato NEXUS para poderem ser analisados filogeneticamente pelo programa PAUP* versão 4.0, realizado pelo método de Distância. O critério de Distância foi empregado utilizandose o modelo evolutivo F80, eletronicamente indicado pelo programa ModelTest 3.7 $\left(\right.$ PAUP $\left.^{\star}\right)$. Foi realizada uma busca heurística com algoritmo TBR (tree bisection reconnection) resultando em uma árvore de topologia não enraizada. Foram calculados os valores de bootstrap, com 100 réplicas, para a verificação da sustentação de ramos nas topologias das árvores obtidas. 
Tabela 3. Tabela de sequências nucleotídicas utilizadas para o alinhamento e filogenia, e suas respectivas: abreviações, nomes utilizados neste trabalho; nomes verdadeiros, nomes da sequências no GenBank; e números de acesso no GenBank.

\begin{tabular}{|c|c|c|}
\hline Abreviação & Nome verdadeiro & № GenBank \\
\hline LaSota & Newcastle disease virus strain LaSota & AY845400 \\
\hline 39AntarBR & Newcastle disease virus isolate 39/Antarctic/BR & EU930424 \\
\hline 02AntarBR & Newcastle disease virus isolate $02 /$ Antarctic/BR & EU930423 \\
\hline 2665BR & Newcastle disease virus isolate Brasil/2665/2007 & FJ751801 \\
\hline 2675BR & Newcastle disease virus isolate Brasil/2675/2007 & FJ751802 \\
\hline 1773BR & Newcastle disease virus isolate Brasil/1773/2006 & FJ751797 \\
\hline 1777BR & Newcastle disease virus isolate Brasil/1777/2006 & FJ751798 \\
\hline 2331BR & Newcastle disease virus isolate Brasil/2331/2006 & FJ751800 \\
\hline 2320BR & Newcastle disease virus isolate Brasil/2320/2006 & FJ751799 \\
\hline Bpositivo & Newcastle disease virus isolate vaccine B1/BR (controle positivo) & EU930425 \\
\hline B1 & Newcastle disease virus B1 & AF309418 \\
\hline PorcinJL1 & Porcine paramyxovirus strain $\mathrm{JL}-1$ & EU546165 \\
\hline Indon904 & Newcastle disease virus strain moluccan/Indonesia/904/87 & AY444497 \\
\hline PHYLMV42 & Newcastle disease virus strain PHY-LMV42 & DQ097394 \\
\hline Oncolytic & Oncolytic Newcastle Disease Virus Strain Italien & EU293914 \\
\hline Velogenic & Velogenic Newcastle disease virus & AF431744 \\
\hline antigenic & Antigenic variant Newcastle disease vírus isolated in Korea & DQ839397 \\
\hline mukteswar & Newcastle disease virus strain mukteswar & EF201805 \\
\hline KBNP4152 & Newcastle disease virus strain KBNP-4152 & DQ839397 \\
\hline China2000 & Newcastle disease virus isolate chicken/China/Guangxi1/2000 & DQ485248 \\
\hline duckChina & $\begin{array}{l}\text { Newcastle disease virus isolate Muscovy } \\
\text { duck/China(Fujian)/FP1/02 }\end{array}$ & DQ403244 \\
\hline SRZO3 & Newcastle disease virus strain SRZ03 & EU167540 \\
\hline Chin2000b & Newcastle disease virus isolate chicken/China/Guangxi4/2000 & DQ485251 \\
\hline China2002 & Newcastle disease virus isolate chicken/China/Guangxi6/2002 & DQ485253 \\
\hline China2003 & Newcastle disease virus isolate chicken/China/Guangxi11/2003 & $\begin{array}{l}\text { DQ485231 } \\
\text { (continua) }\end{array}$ \\
\hline
\end{tabular}


Tabela 3. (continuação)

\begin{tabular}{|c|c|c|}
\hline Abreviação & Nome verdadeiro & № GenBank \\
\hline doveltaly & Newcastle disease virus isolate dove/ltaly/2736/00 & AY562989 \\
\hline US1083 & $\begin{array}{l}\text { Newcastle disease virus isolate } \\
\text { chicken/U.S.(CA)/1083(Fontana)/72 }\end{array}$ & AY562988 \\
\hline It2736 & Newcastle disease virus isolate lt2736 & AY131275 \\
\hline gooseSF02 & Goose paramyxovirus SF02 & AF473851 \\
\hline Fontana & Newcastle disease virus isolate Fontana & U25829 \\
\hline GMChina & Newcastle disease virus strain GM from China & DQ486859 \\
\hline China2005 & Newcastle disease virus isolate dove/Guangxi15/2005 & DQ485273 \\
\hline US71 & Newcastle disease virus isolate mixed species/U.S./Largo/71 & AY562990 \\
\hline GXswine01 & Newcastle disease virus strain GXswine01 & EU346661 \\
\hline ItalyMiln & Newcastle disease virus isolate Italy-Milano & AF124442 \\
\hline US19120 & $\begin{array}{l}\text { Newcastle disease virus strain yellow nape } \\
\text { parrot/U.S.(MA)/19120/87 }\end{array}$ & AY444496 \\
\hline Mexic6244 & Newcastle disease virus isolate chicken/Mexico/6244/98 & AY246047 \\
\hline USOK32932 & Newcastle disease virus strain parrot/U.S.(OK)/32932/96 & AY444500 \\
\hline USFI44083 & $\begin{array}{l}\text { Newcastle disease virus isolate anhinga/U.S. } \\
(\mathrm{FI}) / 44083 / 93\end{array}$ & AY562986 \\
\hline Mexico1 & Newcastle disease virus isolate Mexico1 & AF124453 \\
\hline CMich & Newcastle disease virus isolate C-Mich & AF124451 \\
\hline USCA9547 & Newcastle disease virus isolate Dove/U.S.(CA)/9547/03 & AY438667 \\
\hline Mexic6248 & Newcastle disease virus isolate chicken/Mexico/6248/99 & AY246048 \\
\hline TurkeyND & Newcastle disease virus isolate Turkey/ND & U25836 \\
\hline Sterna & Newcastle disease virus strain Sterna/Astr/2755/2001 & AY865652 \\
\hline It3286 & Newcastle disease virus isolate lt3286 & AY131279 \\
\hline F48E9 & Newcastle disease virus strain F48E9 & AF089819 \\
\hline $98 \mathrm{i} 1252$ & Newcastle disease virus isolate 98-1252 & AY935493 \\
\hline $99 i 0655$ & Newcastle disease virus isolate 99-0655 & AY935494 \\
\hline Ulster67 & Newcastle disease virus isolate chicken/N.Ireland/Ulster/67 & AY562991 \\
\hline isolatel2 & Newcastle disease virus isolate I-2 & AY935499 \\
\hline
\end{tabular}




\section{RESULTADO}

\subsection{Padronização}

O teste de sensibilidade analítica da reação de qPCR com os primers de matriz (M), foram feitos com diluições seriadas na base 4 do cDNA obtido de uma amostra padrão da cepa Ulster, passada em ovo embrionado e previamente positiva no teste de hemaglutinação (HA) com título de 128 unidades hemaglutinantes. $O$ resultado das diluições pode ser visto na llustração 20 , no qual se pode observar a alta sensibilidade analítica da reação que chegou a detectar uma amostra positiva diluída até a aproximadamente 16.000 vezes. Segundo o fabricante, a sensibilidade técnica do equipamento é de 10 cópias do gene RNase P de DNA genômico humano em condições básicas de reações.

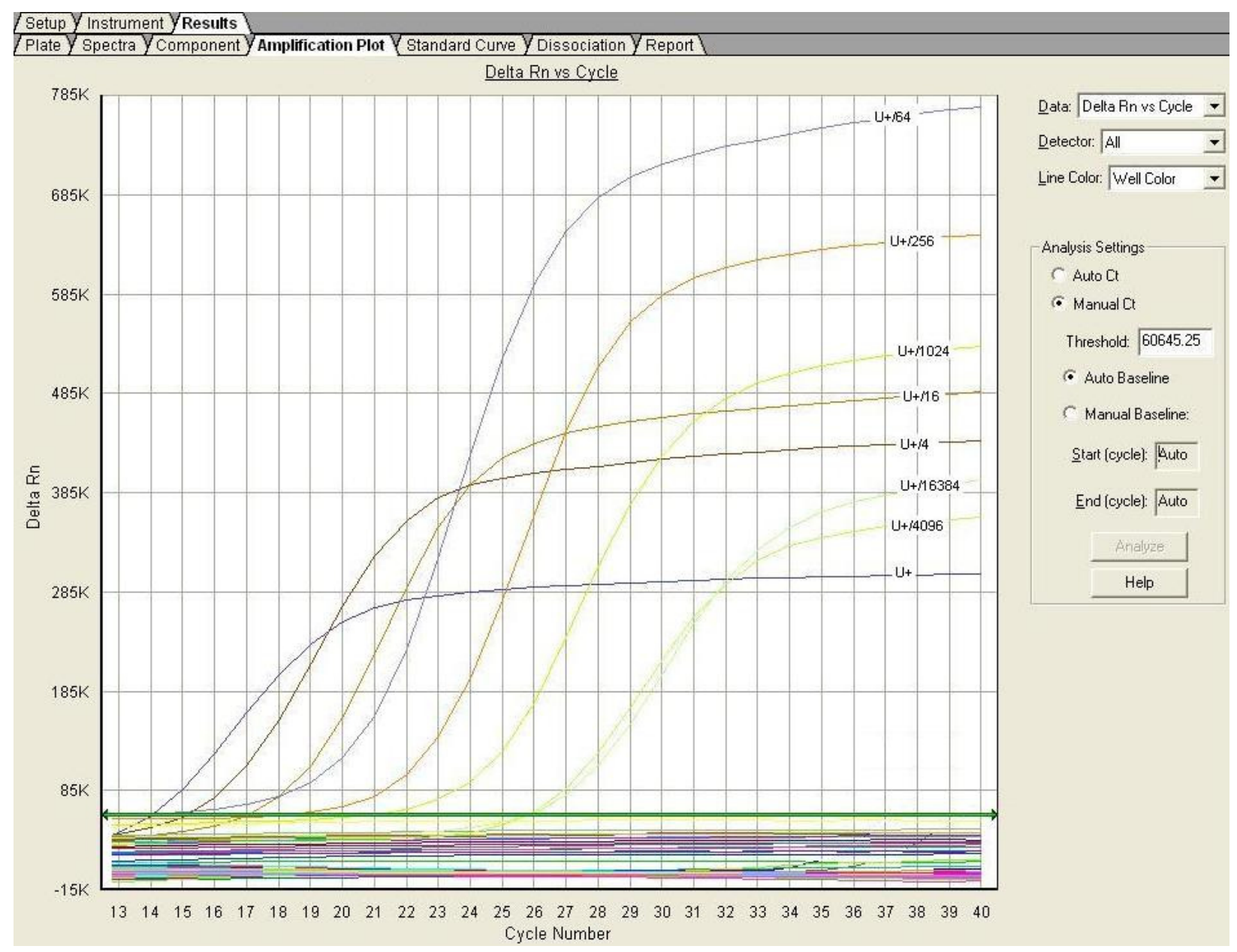

Ilustração 20- Gráfico gerado pelo software 7300 System SDS, mostrando a amplificação das diluições seriadas na base 4 de uma amostra positiva padrão da cepa Ulster $\left(U_{+}\right)$. $\mathrm{O}$ gráfico representa Delta Run versus Cycle, ou seja, sinal repórter normalizado decrescido do sinal da linha de base versus o número do ciclo. 
Para o teste de especificidade analítica, foram utilizados diferentes tipos de amostras, todas diluídas seriadamente $\left(10^{-1}\right.$ a $\left.10^{-5}\right)$, foram elas: cDNA obtidos a partir de controles positivos padrões de NDV das cepas vacinais Ulster e La Sota, cDNA obtido da transcrição do RNA de uma cepa de São João de Meriti, também de NDV, porem de linhagem velogênica; cDNA obtido de amostras padrões do vírus da Influenza tipo A e do tipo B; cDNAs de nossa biblioteca de cDNAs de amostras clínicas colhidas no Hospital Universitário: cDNA de vírus respiratório sincicial humano (HRSV), cDNA de metapneumovirus humano e cDNA de parainfluenzavirus I, II e III; e amostras de líquido alantóico de ovos embrionados de galinha livres de patógenos específicos. Todas as amostras (diluídas ou não) de paramyxovirus aviários do tipo 1, ou seja vírus da Doença de Newcastle (Ulster, La Sota e São João de Meriti) foram detectados pela reação de qPCR para o gene de matriz (M), que foi projetado para detectar a maioria dos NDVs conhecidos; enquanto que o restante das amostras bem como os controles negativos não foram detectados, demonstrando a especificidade esperada.

Testamos também a especificidade analítica da reação de qPCR para o gene de fusão $(F)$, que foi projetado para detectar apenas as cepas velogênicas (virulentas = alta patogenicidade) de NDV. Testamos com as mesmas amostras utilizadas para o gene $\mathrm{M}$ e como esperado, desta vez, apenas as diluições provenientes da cepa São João de Meriti foram detectadas, antagonicamente às diluições de todas as outras amostras, sejam de NDV de baixa patogenicidade ou de qualquer outro vírus.

Nota-se que os testes acima realizados não se tratam de testes de sensibilidade e especificidade diagnósticas, uma vez que não foram comparados a nenhuma outra técnica. 


\subsection{Resultado das coletas}

\subsection{1 qPCR}

Foram capturadas e amostradas 1072 aves de cerca de 40 espécies diferentes em três regiões do Brasil (924 no Norte, 98 no Nordeste e 50 no Sul), sendo o pato (Cairina moschata) o amostrado em maior quantidade (69,1\%), seguido de galinhas - Gallus gallus (8,5\%), marrecos de diferentes espécies $(8,1 \%)$, perus - Meliagres gallopavo (5,6\%), charadriiformes de várias espécies $(5,3 \%)$ e passeriformes também diversos (3,4\%). Também foram coletadas amostras de 100 pingüins de três espécies distintas (Pygoscelis adeliae, Pygoscelis Antarctica e Pygoscelis papua) totalizando 1172 aves, sendo 878 domésticas (75\%) e 294 selvagens (25\%), todos sem qualquer sinal clinico da DNC.

Pelo método de qPCR do gene M, 8 amostras (0,75\%) foram consideradas positivas para o NDV em aves provenientes de diferentes regiões do Brasil, sendo 5 delas do Norte (62,5\% das positivas; $0,46 \%$ do total; $0,54 \%$ do Norte), 2 do Nordeste ( $25 \%$ das positivas; $0,18 \%$ do total; $2,04 \%$ do Nordeste) e 1 do Sul $(12,5 \%$ das positivas; $0,09 \%$ do total; $2 \%$ do Sul). Da mesma forma, 2 (2\%) amostras coletadas de pingüins na Antártica foram positivas para o NDV. A localização dos pontos de coleta e o tipo de ave infectada podem ser vistos na llustração 21, a seguir.

Das 5 amostras positivas provenientes da região Norte, uma delas (amostra 844BR) foi obtida de um pato de granja em Vigia de Nazaré, município distante cerca de $100 \mathrm{Km}$ da capital Belém do Pará, durante o ano de 2005. As restantes 4 amostras foram coletadas, também de patos, durante o ano de 2006, sendo duas delas (2320BR e 2331BR) de patos caipiras (de fundo de quintal), no município de Breves na llha de Marajó e duas (1773BR e 1777BR), patos de granja na região de Terra Alta, $80 \mathrm{Km}$ de Belém. As amostras positivas (2665BR e 2675BR) provenientes do Nordeste foram obtidas de maçaricos (Calidris alba e Calidris pusilla) capturados na Ilhota Coroa do Avião na Ilha de Itamaracá, Pernambuco, em 2007. Por fim, a única amostra positiva (2573BR) proveniente da região Sul foi isolada de um ganso doméstico no município de Navegantes em Santa Catarina, durante o ano de 2006.

As duas amostras positivas (02AntarticaBR e 39AntarticaBR) isoladas de pingüins, ambos da espécie Pygoscelis adeliae, foram coletadas na região da península Keller na Antártica durante o ano de 2006. 


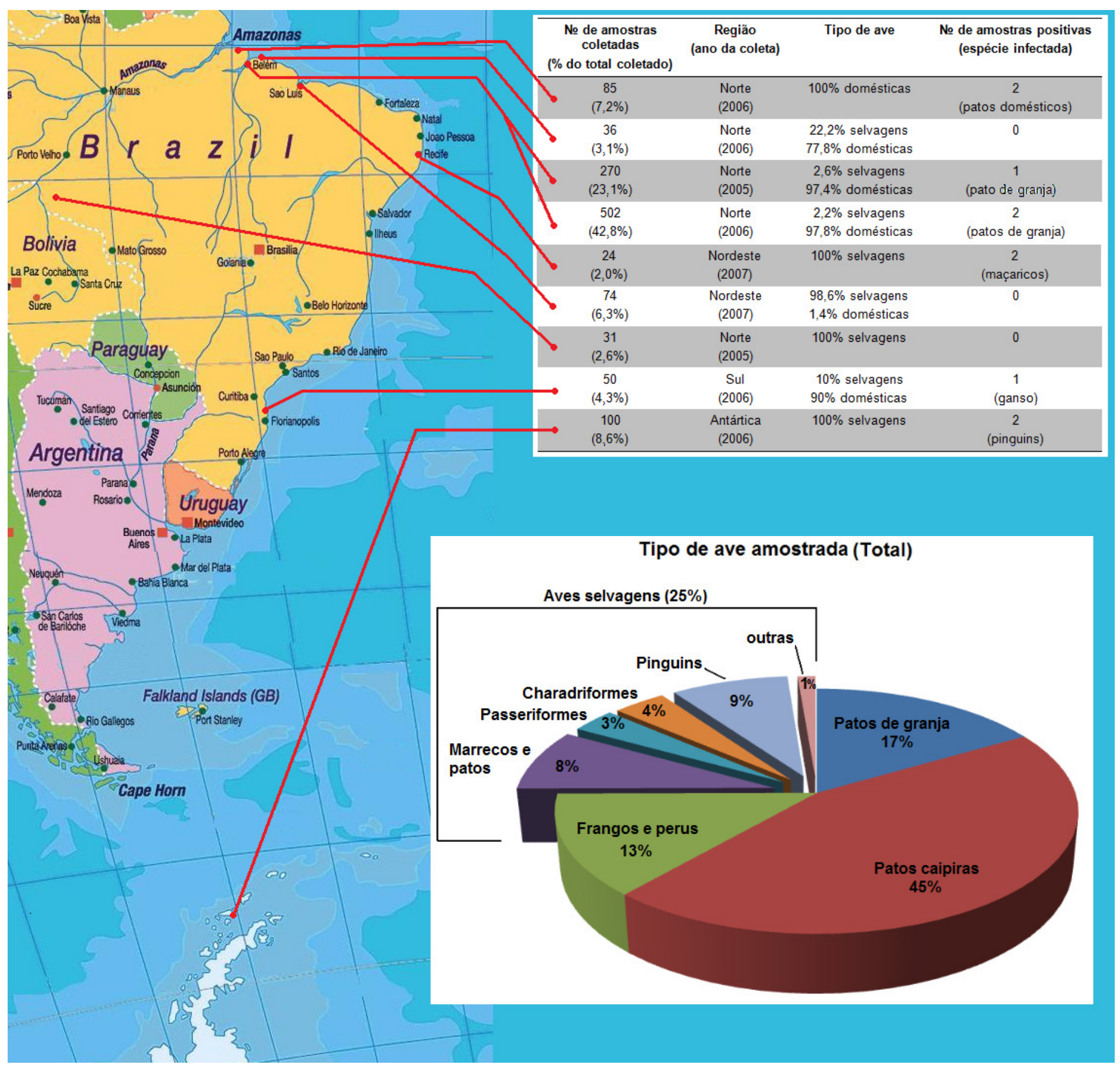

Ilustração 21- Localização dos locais de coleta das amostras positivas para NDV por qPCR, com suas respectivas contribuições para o universo amostral. 


\subsubsection{Isolamento e Sequenciamento}

Todas as amostras positivas, brasileiras e provenientes da Antártica, foram inoculadas em ovos embrionados de galinhas e o isolamento foi confirmado por qPCR.

A virulência dos novos isolados foi determinada por métodos moleculares e biológicos, ou seja, as amostras positivas foram testadas tanto por qPCR do gene $F$, específico para detecção de somente cepas meso/velogênicas, quanto por TME (Tempo médio de morte de embrião), que permite classificar a patogenicidade de acordo com o resultado obtido. Em ambos os testes, todos os isolados foram considerados cepas lentogênicas de NDV, uma vez que nenhum deles foi detectado no primeiro, e no segundo, os resultados de TME de todos foram maiores que 90 horas. Os resultados completos do TME para cada amostra podem ser observados na Tabela 4.

Para obter a relação genética entre os isolados, incluindo cepas de NDV de linhagens de referência e isolados previamente reportados no GenBank, as sequências nucleotídicas do gene $M$ cobrindo as posições nucleotídicas 4100-4220 foram alinhadas e analisadas. $O$ alinhamento das sequências nucleotídicas mostrando as similaridades existentes entre elas pode ser visto na llustração 22, bem como o alinhamento das sequências deduzidas de aminoácidos resultantes, na llustração 23 seguinte. Com o auxilio do programa DNAStar, também foi possível criar uma tabela que mostra a porcentagem de identidade e da distância entre todas as sequências (Tabela 5). O resultado da análise filogenética gerado pelo programa PAUP* está domonstrado na llustração 24. 
Tabela 4- Registro da porcentagem de embriões vivos após a inoculação do isolado para se determinar o tempo médio de morte do embrião (TME) em horas.

\begin{tabular}{|c|c|c|c|c|c|c|c|c|c|c|c|c|c|c|c|}
\hline \multirow{3}{*}{$\begin{array}{l}\text { Número } \\
\text { da } \\
\text { amostra }\end{array}$} & \multicolumn{15}{|c|}{ Porcentagem de embriões vivos x HPI (horas pós infecção) } \\
\hline & \multicolumn{2}{|c|}{ Primeiro dia } & \multicolumn{2}{|c|}{ Segundo dia } & \multicolumn{2}{|c|}{ Terceiro dia } & \multicolumn{2}{|c|}{ Quarto dia } & \multicolumn{2}{|c|}{ Quinto dia } & \multicolumn{2}{|c|}{ Sexto dia } & \multicolumn{2}{|c|}{ Sétimo dia } & \multirow{2}{*}{$\begin{array}{l}\text { TME } \\
\text { (horas) }\end{array}$} \\
\hline & Oh & $12 \mathrm{~h}$ & $24 h$ & $36 h$ & $48 h$ & $60 h$ & $72 h$ & $84 h$ & $96 h$ & $108 \mathrm{~h}$ & $120 \mathrm{~h}$ & $132 h$ & $144 h$ & $156 h$ & \\
\hline 02 Antar & $100 \%$ & $100 \%$ & $100 \%$ & $100 \%$ & $100 \%$ & $100 \%$ & $100 \%$ & $100 \%$ & $100 \%$ & $100 \%$ & $100 \%$ & $100 \%$ & $100 \%$ & $100 \%$ & 156 \\
\hline 39 Antar & $100 \%$ & $100 \%$ & $100 \%$ & $100 \%$ & $100 \%$ & $100 \%$ & $100 \%$ & $100 \%$ & $100 \%$ & $100 \%$ & $100 \%$ & $100 \%$ & $100 \%$ & $100 \%$ & 156 \\
\hline 844 & $100 \%$ & $100 \%$ & $100 \%$ & $100 \%$ & $100 \%$ & $100 \%$ & $66,7 \%$ & $33,3 \%$ & $33,3 \%$ & $33,3 \%$ & $33,3 \%$ & $33,3 \%$ & $33,3 \%$ & $33,3 \%$ & 100 \\
\hline 1773 & $100 \%$ & $100 \%$ & $100 \%$ & $100 \%$ & $100 \%$ & $100 \%$ & $100 \%$ & $100 \%$ & $100 \%$ & $100 \%$ & $100 \%$ & $100 \%$ & $100 \%$ & $100 \%$ & 156 \\
\hline 1777 & $100 \%$ & $100 \%$ & $100 \%$ & $100 \%$ & $100 \%$ & $100 \%$ & $100 \%$ & $100 \%$ & $100 \%$ & $100 \%$ & $100 \%$ & $100 \%$ & $100 \%$ & $100 \%$ & 156 \\
\hline 2320 & $100 \%$ & $100 \%$ & $100 \%$ & $100 \%$ & $100 \%$ & $100 \%$ & $100 \%$ & $100 \%$ & $100 \%$ & $100 \%$ & $100 \%$ & $100 \%$ & $100 \%$ & $100 \%$ & 156 \\
\hline 2331 & $100 \%$ & $100 \%$ & $100 \%$ & $100 \%$ & $100 \%$ & $100 \%$ & $100 \%$ & $100 \%$ & $100 \%$ & $100 \%$ & $100 \%$ & $100 \%$ & $100 \%$ & $100 \%$ & 156 \\
\hline 2573 & $100 \%$ & $100 \%$ & $100 \%$ & $100 \%$ & $100 \%$ & $100 \%$ & $66,7 \%$ & $33,3 \%$ & $33,3 \%$ & $33,3 \%$ & $33,3 \%$ & $33,3 \%$ & $33,3 \%$ & $33,3 \%$ & 100 \\
\hline 2665 & $100 \%$ & $100 \%$ & $100 \%$ & $100 \%$ & $100 \%$ & $100 \%$ & $100 \%$ & $100 \%$ & $100 \%$ & $100 \%$ & $100 \%$ & $100 \%$ & $66,7 \%$ & $66,7 \%$ & 148 \\
\hline 2675 & $100 \%$ & $100 \%$ & $100 \%$ & $100 \%$ & $100 \%$ & $100 \%$ & $100 \%$ & $100 \%$ & $100 \%$ & $100 \%$ & $100 \%$ & $100 \%$ & $100 \%$ & $100 \%$ & 156 \\
\hline Controle B1 & $100 \%$ & $100 \%$ & $100 \%$ & $100 \%$ & $100 \%$ & $100 \%$ & $100 \%$ & $100 \%$ & $100 \%$ & $0 \%$ & $0 \%$ & $0 \%$ & $0 \%$ & $0 \%$ & 96 \\
\hline
\end{tabular}

De acordo com a Secretaria Nacional de Defesa Agropecuária, o TME se classifica em: Velogênica - menor que 60 horas; Mesogênica - entre 60 e 90 horas; Lentogênica - maior que 90 horas. 


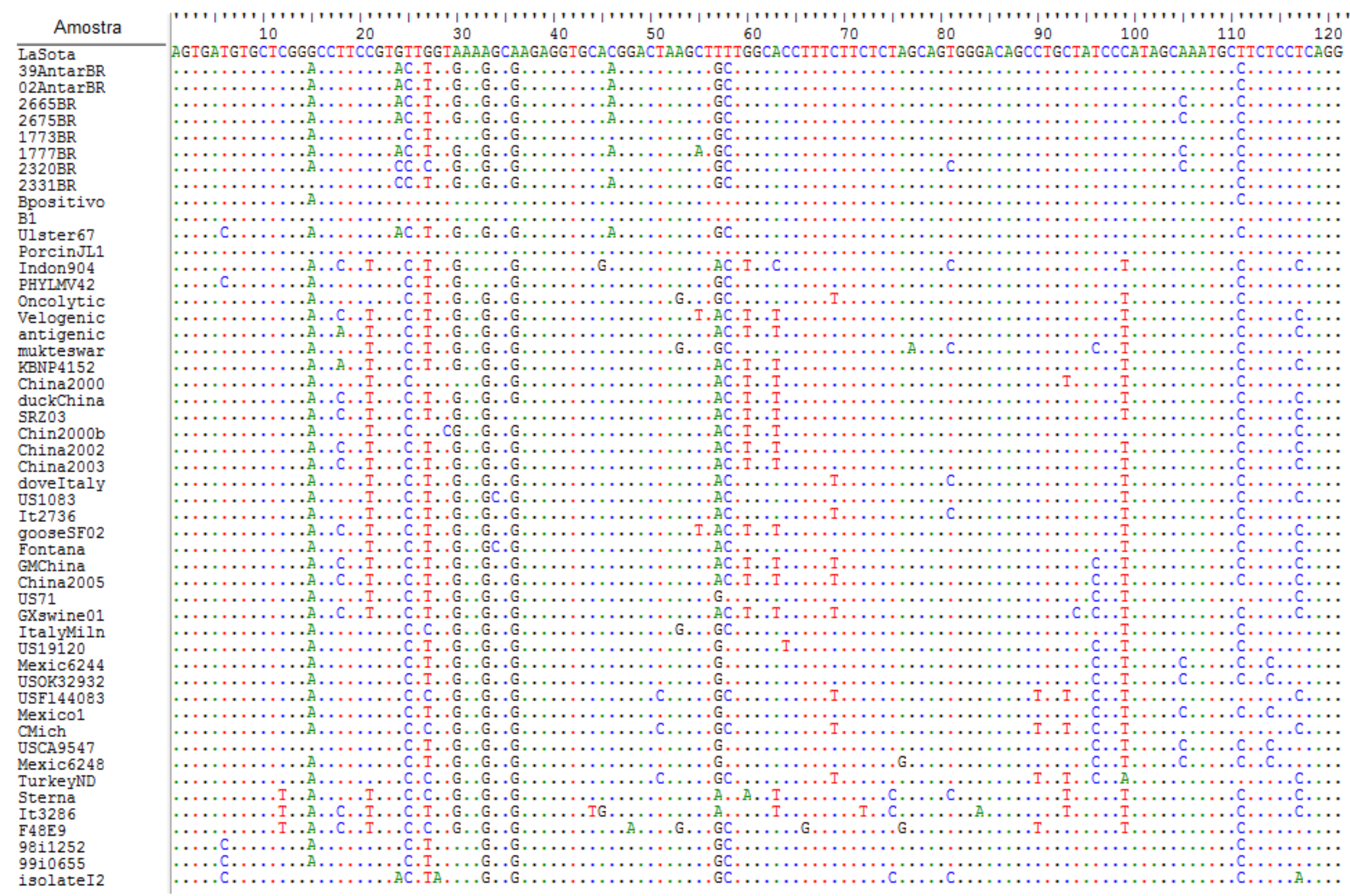

llustração 22. Alinhamento das sequências nucleotídicas parciais do gene $M$, a partir das sequências genômicas de NDV detectados nas aves estudadas (amostras com terminação BR) e de outras provenientes do GenBank, realizado pelo programa BioEdit Sequence Alignment Editor versão 6.0.7. Os pontos representam as similiraridades existentes entre as sequências em relação à cepa LaSota. 


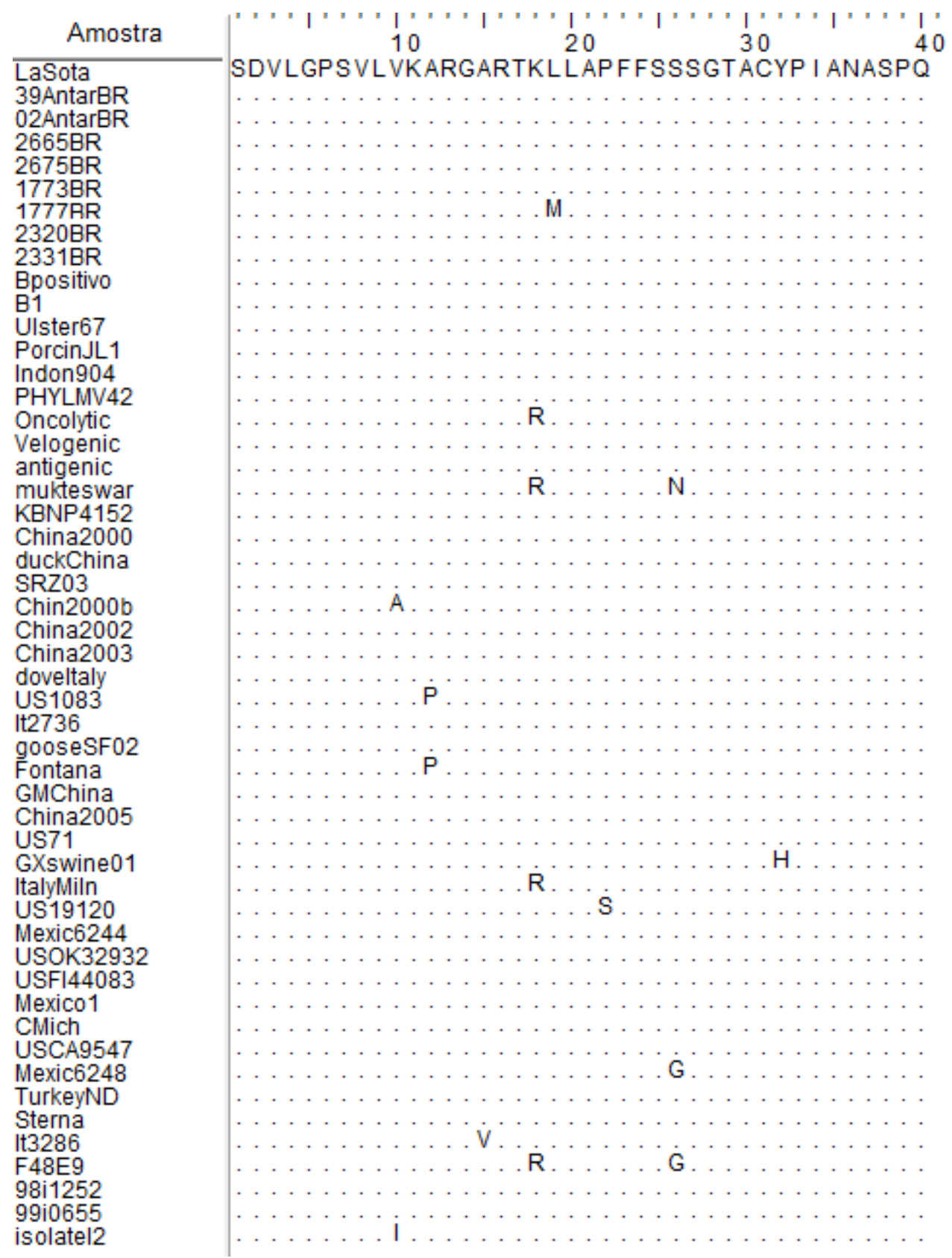

llustração 23- Alinhamento das sequências deduzidas de aminoácidos a partir das sequências nucleotídicas parciais do gene M de NDV detectados nas aves estudadas (amostras com terminação BR) e de outras provenientes do GenBank, realizado pelo programa BioEdit Sequence Alignment Editor versão 6.0.7. Os pontos representam as similiraridades existentes entre as sequências em relação à cepa LaSota. 
Tabela 5- Tabela de porcentagem de identidade (acima da diagonal) e distância (abaixo da diagonal) entre as sequências nucleotídicas para o fragmento de 121 pb do gene $\mathrm{M}$ entre os NDVs detectados (em destaque vermelho) e outros conhecidos. Os resultados estão em inglês, ou seja, as casas decimais estão separadas por pontos.

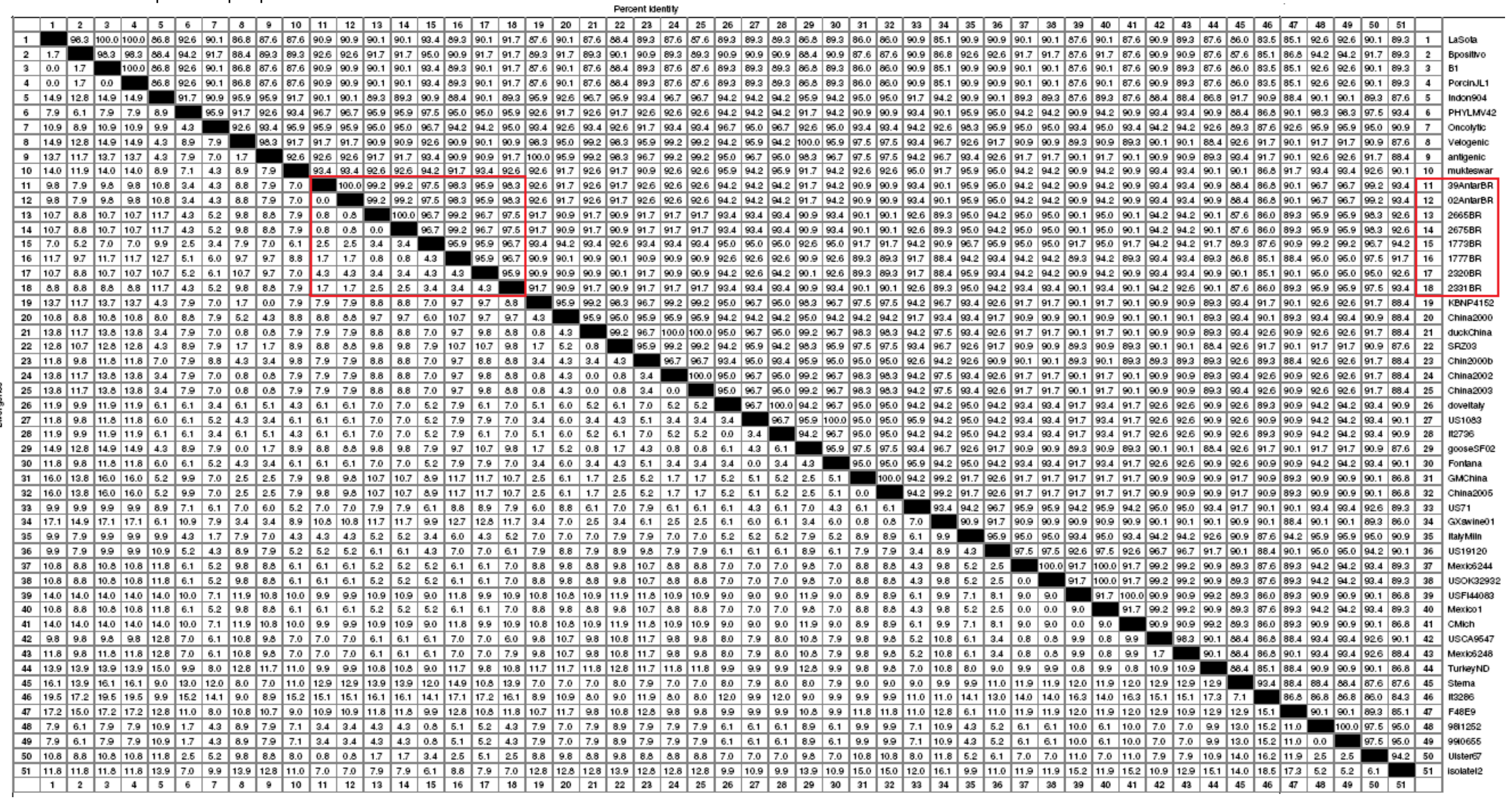




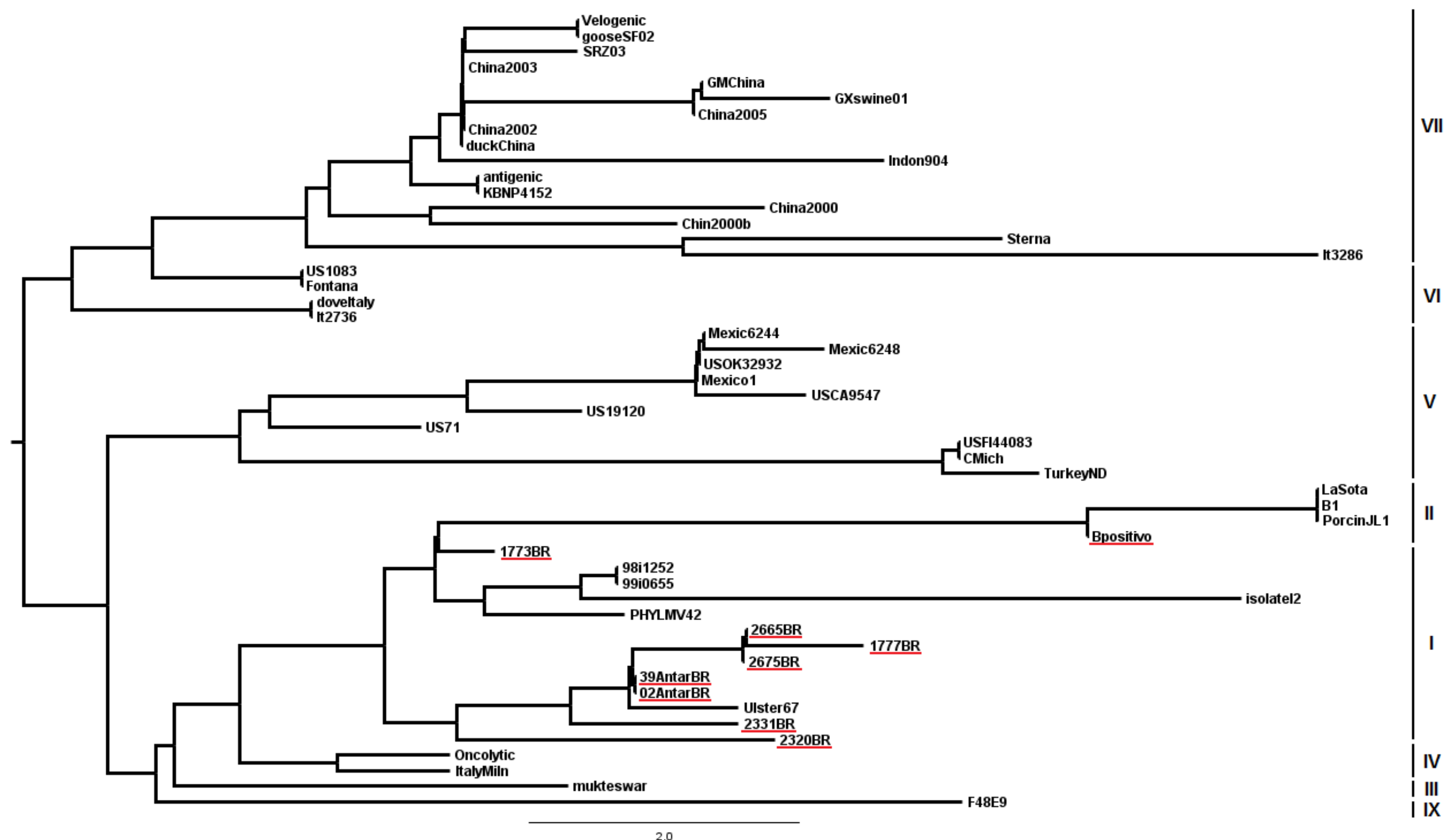

Ilustração 24- Árvore filogenética dos isolados de NDV baseado no seqüenciamento nucleotídico da região genômica parcial do gene M. As sequências de referencias foram obtidas do GenBank (para o № de acesso e nome completo, ver Tabela 3). Os isolados reportados neste trabalho, bem como o controle positivo vacinal utilizado, estão sublinhados em vermelho. A escala representa substituições nucleotídicas (x100). 


\subsubsection{Sorologia}

O prévio contato com o NDV, pelas aves estudadas, foi investigado através do teste de $\mathrm{HI}$, realizado no soro coletado durante as expedições volantes e durante a expedição antártica. O estudo sorológico não foi realizado no restante das amostras (expedições anuais), uma vez que todo o soro coletado nelas foi utilizado para o estudo paralelo do vírus da influenza aviária.

Das 269 amostras de soros provenientes de aves de diferentes regiões do Brasil, 5 (1,85\%) apresentaram atividade anti-hemaglutinante para o NDV, com títulos variando entre 40 e 80 . Destas, uma amostra foi proveniente de um pato doméstico no Pará e quatro, provenientes de marrecos selvagens no Maranhão. As amostras, os títulos de HI, bem como os locais de coleta, estão expostos na Tabela 6.

Tabela 6- Resultados positivos pelo teste de $\mathrm{HI}$, das amostras de soros colhidas durante as expedições volantes.

\begin{tabular}{ccc}
\hline Número da amostra & Título HI & Local da coleta \\
\hline $2329 B R$ & $\leq 80$ & Breves, llha do Marajó \\
$2584 B R$ & $\leq 80$ & São Bento, Maranhão \\
$2600 B R$ & $\leq 40$ & São Bento, Maranhão \\
$2608 B R$ & $\leq 40$ & São Bento, Maranhão \\
$2636 B R$ & $\leq 80$ & Cajapió, Maranhão \\
\hline
\end{tabular}

Dentre as amostras de soros provenientes de pingüins na Antártica, os titulos de $\mathrm{HI}$ variaram entre 40 e 640 , sendo que $23(33,3 \%)$ dos 69 soros coletados apresentaram anticorpos para o NDV (Tabela 7). 
Tabela 7. Resultados do teste de HI realizados em soros de pingüins coletados na Antártica.

\begin{tabular}{|c|c|c|c|c|c|c|c|c|c|c|c|c|c|c|c|c|c|c|c|c|}
\hline & \multicolumn{20}{|c|}{ Amostras de soro } \\
\hline & 01 & $02^{*}$ & 03 & 06 & 07 & 08 & 10 & 11 & 12 & 13 & 15 & 16 & 17 & 18 & 21 & 22 & 26 & 28 & 29 & 31 \\
\hline \multirow[t]{3}{*}{ NDV } & 40 & 40 & 40 & 40 & - & - & - & - & - & 80 & 40 & - & 40 & - & - & - & - & 80 & - & - \\
\hline & \multicolumn{20}{|c|}{ Amostras de soro } \\
\hline & 33 & 34 & 35 & 38 & $39^{*}$ & 40 & 42 & 43 & 44 & 45 & 47 & 49 & 50 & 51 & 52 & 53 & 55 & 56 & 59 & 60 \\
\hline \multirow[t]{3}{*}{ NDV } & - & 40 & - & 80 & 40 & 80 & - & - & - & - & - & - & - & - & - & - & 80 & - & 40 & - \\
\hline & \multicolumn{20}{|c|}{ Amostras de soro } \\
\hline & 61 & 62 & 64 & 69 & 70 & 71 & 72 & 76 & 77 & 78 & 79 & 81 & 82 & 83 & 84 & 85 & 86 & 87 & 88 & 90 \\
\hline \multirow[t]{3}{*}{ NDV } & - & 320 & - & 40 & - & 80 & 320 & - & - & - & 40 & - & - & 40 & - & 320 & - & - & - & 640 \\
\hline & \multicolumn{20}{|c|}{ Amostras de soro } \\
\hline & 92 & 93 & 94 & 95 & 96 & 97 & 98 & 99 & 100 & & & & & & & & & & & \\
\hline NDV & - & - & - & - & - & - & 80 & - & - & & & & & & & & & & & \\
\hline
\end{tabular}

${ }^{*}$ Amostras positivas por qPCR 


\section{DISCUSSÃO}

\subsection{NDV no Brasil}

Grande parte de nossa amostragem ( $58 \%$ do total) foi proveniente de criações de aves domésticas não comerciais, também conhecidas como criações de "fundo de quintal" ou aves caipiras, e descritas na literatura como "frangos de vila". O estudo de aves provenientes de criações domésticas é importantíssimo, dado a diversidade de fatores que tornam tais criações muito suscetíveis à DNC em caso de uma possível chegada da doença ao Brasil. Os principais fatores que podemos citar são: diversidade de espécies animais, não apenas aviárias, compartilhando o mesmo espaço; dificuldade de vacinação; falta de cuidados sanitários, contato com animais silvestres e poucos cuidados com a biossegurança. Além disso, em muitas áreas, as pequenas criações domésticas nunca tiveram uma experiência prévia com o NDV, assim, quando o vírus é introduzido, a falta de anticorpo faz com que ele se dissemine rapidamente.

Manchang (2004) descreveu que na Nigéria, onde a DNC é endêmica, acreditase que os frangos caipiras sejam os responsáveis por manter a circulação do NDV virulento. Isto porque nas criações domésticas, existe uma mistura em termos de suscetibilidade à infecção pelo NDV, por causa da variação de espécies, imunidade devido à idade, exposição ao NDV e por causa de condições extremas, que fazem com que a disseminação do vírus ave a ave não ocorra tão rapidamente como em criações intensivas comerciais. Ainda em relação à Nigéria, a introdução do NDV em criações domésticas ocorre principalmente quando frangos vivos infectados são introduzidos. Mercados de aves vivas são provavelmente os maiores meios de dispersão, principalmente porque muitos criadores levam as aves ao mercado assim que ficam doentes, na tentativa de recuperarem o investimento. Mas outros meios de introdução de novas linhagens de NDV para as criações domésticas incluem aves silvestres, transporte de frangos vivos infectados entre as criações, carcaças infectadas e a movimentação de objetos de um sítio infectado.

Todas as condições descritas acima para a Nigéria ocorrem no Brasil, principalmente nas regiões Norte e Nordeste, com a diferença que aqui, tal doença é exótica, pelo menos em relação às linhagens virulentas. Isto torna o presente estudo ainda mais relevante em termos de vigilância epidemiológica do NDV, uma vez que 
o isolamos em $0,75 \%$ das aves estudadas em diferentes regiões do Brasil, demonstrando que a circulação do vírus já ocorre e que numa eventual aparição da cepa velogênica, a disseminação poderia ser bastante rápida. Apesar de todas as a cepas isoladas neste trabalho pertencerem às linhagens lentogênicas (de baixa patogenicidade) de NDV, comprovadas tanto molecularmente (qPCR) quanto por testes biológicos (TME entre 100 e 156h), tais resultados demonstram a sucetibilidade das aves brasileiras ao NDV, circulando tanto entre as aves domésticas, quanto selvagens.

A maior parte de nossa amostragem foi proveniente de patos e marrecos (70\% do total, sendo $13,3 \%$ deles selvagens e $86,7 \%$ domésticos) não por acaso, eles foram priorizados, pois merecem uma consideração especial. Os patos são reportados por serem rapidamente infectados pelo NDV e serem capazes de disseminá-lo por longos períodos de tempo, sem apresentarem sinais clínicos da doença. Existem poucos relatos de sinais clínicos da DNC em patos, enquanto que muitos autores descrevem uma elevada taxa de NDV carreados por eles. $O$ problema está justamente nas aves que são clinicamente saudáveis, mas incubam o vírus e os disseminam. Por exemplo, Kingston e Dharsana (1979) descreveram que em uma vila na Indonésia, o NDV persistiu por um ano num grupo de apenas 300 patos. Estudando-se estes vírus e associando-o com linhagens do Vietnã, descobriuse que tais vírus isolados de patos assintomáticos eram virulentos para frangos. Num recente encontro da FAO no Marrocos, foi observado que na Tanzania a DNC é um grande problema para criadores domésticos de frangos onde patos também são mantidos.

Da mesma forma que a maior parte da amostragem foi proveniente de patos e marrecos, 75\% das amostras positivas (6/8) para o NDV foram provenientes desses animais. Porém, apesar das aves caipiras representarem 58\% da amostragem, apenas $37,5 \%$ das amostras positivas (3/8) foi proveniente delas, o mesmo número de amostras positivas encontrado em patos de granja que representaram $17 \%$ do universo amostral. Isso pode ser explicado pela proximidade dos lotes aos de outros animais que podem ter sido vacinados ou até mesmo pela própria proximidade entre os animais que numa criação intensiva é muito grande e facilita a dispersão e manutenção do NDV, além disso, as granjas estudadas não possuíam cuidados quanto ao contato com outros animais silvestres, uma vez que observamos 
passeriformes alimentando-se nos comedouros junto aos patos ou outras formas de contato em todas elas.

Silva (2006) isolou NDV vacinal de swabs cloacais de passeriformes (tico-tico) em fazendas de criação comercial de frangos, bem como detectou a presença de anticorpo anti-NDV nestas espécies, sugerindo que os tico-ticos tenham provavelmente se infectado pela ingestão de partículas virais provenientes da água usada para a vacinação dos criatórios. Da mesma forma que os passeriformes podem infectar-se com linhagens vacinais, a recíproca pode ocorrer e assim, os passeriformes que trariam o NDV (em circulação) para as criações. Gustafson (1953) demonstrou que em infecções experimentais de NDV em tico-ticos, estes podem transmitir o vírus a outras aves sussetíveis através do convívio. Por isso, é fundamental que medidas de manejo adequadas sejam adotadas a fim de evitar o contato de aves silvestres com plantéis comerciais, reduzindo o risco de uma infecção pelo NDV.

Em nenhum dos patos ou marrecos selvagens foi encontrado o vírus, porém quatro, das cinco amostras de soro contendo anticorpos para o NDV, foram provenientes de marrecos selvagens de São Bento no Maranhão. A outra amostra de soro positiva foi proveniente de um pato doméstico de Breves na llha do Marajó. Estas amostras representam $1,85 \%$ dos soros coletados e a taxa de positividade poderia ser ainda maior, uma vez que alguns soros apresentavam algum sinal de hemólise $(\approx 10 \%)$ e outros tiveram de ser diluídos em PBS $(\approx 20 \%)$, devido ao pequeno volume de sangue que se pode tirar das aves de menor porte. Mesmo assim, estes resultados são bastante semelhantes ao encontrado por Oliveira Júnior (2003) que analisou por HI, soros de 837 aves silvestres livres ou cativas, e aves domésticas não vacinadas do Zoológico Municipal do Rio de Janeiro e de propriedades particulares nos municípios de Seropédica, Japeri, Paulo de Frontin, Paracambi, Valença, Barra do Piraí, Rio de Janeiro e Nova Friburgo, no período de agosto de 1998 a julho de 2001, encontrando anticorpos anti-NDV em 1,43\% deles.

Outras aves silvestres, com hábitos aquáticos, que se destacaram neste trabalho foram as do gênero Calidris sp, vulgarmente chamadas de maçaricos, que representaram apenas $2,7 \%$ da amostragem mas $25 \%$ das amostras positivas (2/8). Foram os únicos representantes de aves silvestres dos quais foram isolados o NDV neste trabalho (exceto pingüins). Este resultado é preocupante uma vez que os maçaricos são considerados aves migratórias e são encontrados em praticamente todo o litoral brasileiro. Uma subespécie que ocorre no 
Brasil, o Calidris canutus rufa, pode migrar até uma distância máxima de $15000 \mathrm{Km}$, ligando o Ártico, no Pólo Norte, ao extremo sul do continente Sul-americano, passando por todo o litoral brasileiro (Buehler, 2008). Mas não apenas os maçaricos causam preocupação, anualmente milhares de aves migratórias de diferentes espécies sussetíveis ao NDV vêm do Hemisfério Norte onde a presença do NDV patogênico em aves silvestres tem sido reportada (Wobeser,1993).

Apesar de termos isolado todas as amostras positivas em ovos embrionados de galinha, a confirmação só foi conseguida através da qPCR (ct entre 35 e 39), na maioria dos casos o teste de HA não resultava em hemaglutinação. Outros autores já haviam descrito a dificuldade de se isolar o NDV de amostras clínicas de aves adultas e saudáveis, especialmente as linhagens de baixa virulência (Sakai, 2006). Acreditamos que o vírus esteja numa concentração tão baixa que apenas a qPCR seja capaz de detectá-la. Kubista (2006) descreveu que com a tecnologia da qPCR, os químicos altamente eficientes de detecção, instrumentação sensível, e reações otimizadas que estão disponíveis, o número de moléculas de DNA de uma sequência em particular dentro de uma amostra pode ser determinado com uma acurácia sem precedentes e sensível suficiente para detectar uma única molécula. Quando realizamos uma reação de PCR normal (sem ser em tempo real), para o posterior seqüenciamento nucleotídico dos isolados, as bandas geradas no gel de agarose $2 \%$ foram tão fracas (dados não mostrados) que não foi possível realizar o seqüenciamento de duas dessas amostras (844BR e 2573BR).

Outra difuculdade encontrada foi que na literatura e nos bancos públicos de sequências nucleotídicas, a maior parte da informação disponível sobre o NDV tratase dos genes das glicoproteínas de superfície funcionalmente importantes, as proteínas hemaglutinina-neuraminidase $(H N)$ e de fusão $(F)$. Por isso não foi possível classificar com precisão os novos isolados quanto ao genótipo. Porém, observando-se a árvore filogenética (Ilustração 24) gerada a partir do alinhamento destes, com os poucos fragmentos das sequências nucleotídicas disponíveis para o gene $\mathrm{M}$, podemos visualizar que os isolados formam um subclado, relacionado com a cepa lentogênica Ulster, com exceção da amostra 1773BR que ficou mais próxima dos isolados 98i1252, 99i0655 e PHYLMV42. Além disso, a alta similaridade existente entre os isolados, 95,7 a 100\%, demonstrada na Tabela 5, indica que eles são bastante próximos e que compartilham um ancestral comum. Como já descrito por outros autores (Herczeg, 1999; Lomniczi, 1998; Yang, 1997), vírus 
compartilhando parâmetros temporais, geográficos, antigênicos ou epidemiológicos tendem a cairem em linhagens específicas, fato este que tem se provado valioso no estudo da disseminação do NDV.

Lomniczi (1998) citou diversos autores (Sakaguchi, 1989; Toyoda, 1989; Seal, 1995 e 1996) para sugerir que a análise filogenética baseada em sequências totais dos genes $\mathrm{F}$ ou HN das linhagens de NDV dos grupos I a IV e usando o gene M inteiro de linhagens representando grupos I a $V$ produzem a mesma topologia básica de árvore. Mesmo quando utilizados pequenos fragmentos (232 pb do gene $\mathrm{M}$ ), relações genéticas equivalentes foram obtidas quando comparadas a aquelas de sequências inteiras dos genes, mostrando que o uso de relativamente pequenas sequências de diferentes regiões subgenéticas são adequadas para a identificação de genótipos e não influenciam significantemente nos valores de distâncias genéticas. Embasado nestes estudos e nos dados obtidos do alinhamento e da análise filogenética, que mostram todos os grupos genéticos (I a IX, com exceção do grupo VIII) reunidos em subclados, podemos inferir que os novos isolados (1773BR, 1777BR, 2320BR, 2331BR, 2665BR e 2675BR) pertencem ao genótipo I, grupo da cepa lentogênicas Ulster a qual tiveram maior identidades, incluindo $O$ isolado 1773BR que ficou entre as cepas velogênicas 98i1252/99i0655 e a cepa lentogênica PHYLMV42, todas também do genótipo I.

Interessante ressaltar que, além da cepa Ulster ser amplamente utilizada como vacina no Brasil e no mundo, segundo Ballagi-Pordány (1996) os vírus do grupo genético I compreendem principalmente linhagens lentogênicas originárias de aves aquáticas. Todos os vírus aqui detectados são de linhagens lentogênicas e foram provenientes de aves com hábitos aquáticos, incluindo as amostras de pingüins. As exceções ao grupo (cepas velogênicas 98 i1252 e 99i0655) são linhagens relacionadas à cepa lentogênica $\mathrm{V} 4$, também muito utilizada como vacina, que causaram inúmeros surtos na Australia entre 1998 e 2000. Mais de 1,9 milhões de aves em granjas, fazendas de avestruzes e de patos foram destruídas. $O$ custo total do governo australiano para adiministrar a crise exedeu 25 milhões de dólares australianos (Animal Health Australia - AHA, 1999).

Ainda com relação ao alinhamento das sequências nucleotídicas é possível observar na llustração 22, o quanto este fragmento de gene é conservado, e consequentemente, a elevada similaridade entre as sequências (87-100\%). Sobretudo, considerando o alinhamento das sequências deduzidas de aminoácidos 
(Ilustração 23), mostra uma similaridade ainda maior (98-100\%), resultante de muitas mutações silenciosas que ocorreram nas sequências nucleotídicas, mas que não alteraram as sequências de aminoácidos. Comparando as sequências deduzidas de aminoácidos dos novos isolados à sequência de aminoácidos da cepa padrão La Sota, podemos notar que são idênticas, salvo a amostra 1777BR que possui uma substituição do aminoácido Leucina (L) por Metionina (M). Isso porque quase todas as mutações que ocorreram nas sequências de nucleotídeos dos novos isolados foram do tipo silenciosa, assim como na maioria das sequências da literatura. A única mutação resultante em alteração de aminoácido ( $L$ por $M$ na posição 19) foi do tipo conservativa, ou seja, trocou-se a Leucina, pertencente ao grupo dos aminoácidos não polares alifáticos, pela Metionina, do mesmo grupo. Este tipo de mutação modifica em menor intensidade a estrutura molecular, pois mantém próximos os parâmetros de polaridade e hidrofobicidade (Nelson, 2005).

Por fim, nossos resultados sugerem que o NDV de baixa patogenicidade esteja circulando por todo o Brasil, uma vez que foi isolado, em maior ou menor proporção, de aves de todas as regiões estudadas. Ele foi detectado em aves da região Norte (5/924), Nordeste (2/98) e Sul (1/50). Outros trabalhos da literatura, também têm descrito a circulação do NDV no Brasil: o já citado trabalho de Oliveira Júnior (2003) que encontrou 12 aves soropositivas em 837 pesquisadas no Rio de Janeiro; Sales (2007) também observou a ocorrência de títulos altos de anticorpos em $12 \%$ das galinhas de fundo de quintal estudadas na região de Feira da Santana na Bahia; o trabalho de Orsi (2007) em concordância com o Programa de Sanidade Avícola do MAPA, que estudou o NDV em aves comerciais em áreas de produção/exportação em granjas no Sul (Paraná, Santa Catarina e Rio Grande do Sul), Sudeste (Minas Gerais e São Paulo) e Centro-Oeste (Goiás, Distrito Federal, Mato Grosso e Mato Grosso do Sul), mostrando que mesmo em regiões onde ocorreu a vacinação, houve a circulação de vírus não patogênicos com ICPI (índice de patogenicidade intracerebral) diferentes dos vacinais; o trabalho de Oliveira Júnior (2005) que isolou uma cepa mesogênica de patos domésticos (Neta sp) sintomáticos (incoordenação motora, diarréia e secreção respiratória) em uma pequena propriedade rural no município de Japeri, Rio de Janeiro; e por fim um boletim eletronico epidemiológico da Secretaria de Vigilância em Saúde (SVS, 2004), que realizou em 2003 na região de Galinhos no Rio Grande do Norte, um inquérito sorológico de aves silvestres e testes laboratoriais em swabs de 388 aves divididas 
em 22 pools, dos quais 22,7\% apresentaram resultados positivos, além do isolamento do NDV de linhagem patogênica em 3 aves migratórias, incluindo um maçarico (Calidris pusilla).

Devido ao presente estudo ter isolado o NDV tanto de aves provenientes de granjas, quanto de aves silvestres e aves caipiras de locais ermos, com pouca ou nenhuma interferência de possíveis infecções de NDV por ações humanas, seja proposital como a vacinação, por exemplo, seja por meios não intencionais, como o transporte de animais ou objetos contaminados entre as criações, podemos inferir que as aves silvestres, migratórias ou não, bem como as criações de aves não comerciais, sobretudo as aquáticas, estejam agindo como carreadores ou até mesmo reservatórios do NDV de baixa patogenicidade, e que provavelmente 0 prévio contato com o vírus se deu por infecção natural, já que os resultados sorológicos detectaram a presença de anticorpos anti-NDV principalmente em aves aquáticas silvestres.

Vírus não virulentos isolados de aves selvagens ou domésticas não vacinadas podem fazer parte de um importante reservatório de NDV, principalmente porque a emergência de linhagens virulentas de NDV a partir de vírus não patogênicos mantidos em aves silvestres tem sido frequentemente documentada (Alexander, 1992; Collins, 1993 e 1998; Gould, 2001). Por isso, os resultados ora apresentados destacam a importância de se manter as medidas estritas de biossegurança, bem como a necessidade de criação de um programa de vacinação que incluísse as pequenas criações não comerciais.

O uso da qPCR neste trabalho para detectar o genoma do NDV em swabs aviários, e até mesmo nos isolados, frente aos métodos tradicionais, pôde aumentar a sensibilidade, especificidade e reduziu o tempo de diagnóstico, bem como se mostrou uma ferramenta vantajosa no estudo epidemiológico do NDV. Mas é fundamental que outros estudos na área de vigilância epidemiológica de NDV sejam realizados continuamente e com maior freqüência, monitorando populações aviárias em geral e enfatizando a necessidade de se estudar as diferentes linhagens virais isoladas ao redor do mundo, avaliando a relação vírus-hospedeiro e sua importância na epidemiologia, para que no caso de um surto da doença, este seja detectado o mais precocemente possível, para que as medidas de contenção possam ser tomadas a tempo de evitar uma grande epidemia, que iria incidir de forma bastante negativa na economia do país. 


\subsection{NDV na Antártica}

Mesmo sem qualquer sinal clínico da DNC nos pingüins dos quais foram coletadas as amostras, 33,3\% deles apresentaram anticorpo anti-NDV no soro, indicando um prévio contato com o patógeno. Este indice é bem mais elevado do que o encontrado nas aves brasileiras (1,85\%). Os títulos variando entre 40 e 640 também são maiores que os nacionais (40 a 80). Em parte, estes resultados podem ser explicados pela própria ecologia destas aves, bem como o ambiente em que vivem. Os pingüins são aves de hábitos áquaticos que formam colônias que podem exceder 100 mil casais de procriação e que durante o rigoroso inverno permanecem ainda mais unidos. Além disso, algumas espécies de aves migratórias como os petréis, albatrozes e mandriões (skuas) nidificam perto de colônias de pingüins em épocas reprodutivas, inclusive alimentando-se de seus filhotes como predadores oportunistas, sendo que algumas espécies de pingüins durante o inverno austral também viajam longas distâncias para lugares onde o contato com outras aves podem permitir a transmissão do NDV. É sabido que o NDV pode continuar infectivo em fezes por até uma semana em condições favoráveis, no ambiente gelado da Antártica é possível que este tempo seja muito maior. Pelo menos em se tratando de material genético, o guano congelado de pingüins permanecem preservados por centenas de anos em regiões permanentemente congeladas da Antártica e um método para a detecção do RNA viral do influenza neste tipo de material já foi desenvolvido (Briggs, 2003).

Outro fator importante que deve ser considerado na disseminação de doenças na região Antártica é a expansão da atividade humana, tanto turística quanto científica. Esta disseminação poderia se dar por inúmeros mecanismos direto e indireto. As pessoas podem atuar como vetores, tanto trazendo patógenos exóticos para a região como translocando patógenos endógenos. Além disso, o estresse causado pela atividade humana pode reduzir a imunidade, aumentando a patogenicidade e a susceptibilidade para a infecção. Inclusive o frango e seus derivados, como ovos, cascas de ovos e carne congelada podem ser uma fonte de patógenos, uma vez que a carne de frango tem sido relacionada à transmissão de NDV a outras aves. Existe um longo histórico de alimentação de aves antárticas com sobras de alimentos, incluindo frango e ovos em estações antárticas e existe um 
recente relato de um ninho de mandrião contendo diversos ossos de frango. (Diseases of Antarctic Wildlife - report, 1998).

O homem não apenas pode agir indireta e mecanicamente, como também já foi reportado que o NDV pode infectar mamíferos e que a infecção humana ocorre, causando severas conjuntivites com linhagens virulentas do vírus. O NDV já foi isolado de um porco na Indonésia e deve existir outros hospedeiros incomuns, uma vez que há um relato, também na Indonésia, de uma aparente replicação do vírus em caranguejos de uma cultura de arroz (Kingston, 1977 apud Kingston 1979).

Estudos sorológicos revelaram que o NDV parece estar circulando há vários anos na região Antártica. Morgan e Wetsbury (1981) detectaram anticorpos contra o NDV em pingüins adélie (Pygoscelis adeliae) nessa região com uma baixa prevalência (2 positivos em 164 testados), mas suficiente para indicar que eles haviam sido infectados. Em outro estudo, Morgan (1981) relatou que 6\% dos pingüins reais (Eudyptes chrysolophus schlegeli) numa ilha na região sub-Antártica (Macquaire Island), apresentavam anticorpo para o NDV. Apesar de estes trabalhos terem demonstrado o prévio contato dos pingüins estudados ao NDV, eles não isolaram o vírus. Somente oito anos depois, Alexander (1989) estudando o material coletado durante os anos de 1976 a 1979 conseguiu caracterizar nove paramyxovirus aviários isolados de pingüins na Antártica e sub-Antártica, onde $66,7 \%$ reagiram com um anticorpo monoclonal específico para a cepa Ulster 2C, incluindo um isolado que foi classificado como lentogênico do sorotipo APMV-1, ou seja, NDV.

No presente estudo, conseguimos isolar o NDV em $2 \%$ das amostras colhidas e constatamos que também se tratavam de cepas lentogênicas, por testes moleculares (qPCR) e biológicos (TME de 156h para as duas amostras positivas). Assim como os novos isolados brasileiros e os isolados antárticos e sub-Antárticos por Alexander (1989), eles apresentaram uma maior identidade/afinidade com a cepa vacinal Ulster, pertecente ao genótipo I.

O isolamento do NDV, bem como a detecção de anticorpos contra ele, em pingüins apesar de não ser inédito é alarmante, mas deve ser interpretado com cautela, pois pouco se sabe sobre a importância dos pingüins em sua dispersão e a significância destes anticorpos é incerta, ainda que seja sabido, que os pingüins são suscetíveis a linhagens patogênicas e demonstraram sintomas, em estudos com 
pingüins previamente infectados na natureza, mantidos em cativeiros (Pierson e Pfow, 1975 apud Gardner, 1997; Krauss, 1963 apud Gardner, 1997).

Os testes sorológicos indicando anticorpos em diferentes espécies de pingüins e em lugares bastante distantes da Antártica, em diferentes épocas, na ausência de uma epizootia, sugerem que o NDV provavelmente é endêmico e parte normal da ecologia dos pingüins. Porém, pouco é conhecido da patogenicidade destes vírus, qual o papel deles nos relatos de mortalidade em pingüins antárticos, quais outras espécies podem estar envolvidas em sua transmissão ou se é possível os pingüins transmitirem o NDV para outras espécies.

Com os resultados obtidos neste trabalho, ousando um pouco mais, poderíamos sugerir uma outra possibilidade: a de que os pingüins também pudessem ser considerados reservatórios do vírus e carreadores do NDV, uma vez que pingüins da espécie Pygoscelis papua já foram encontrados, junto a outras espécies de pingüins e aves silvestres, na costa sul da Argentina, local onde Zanetti (2005) descreveu ter encontrado anticorpos anti-NDV em 16\% dos pingüins-demagalhães estudados e região na qual maçaricos de várias espécies fazem invernada, incluindo a espécie (Calidris alba) da qual isolamos uma das cepas de NDV, genéticamente relacionada com as cepas isoladas de pingüins Pygoscelis adeliae provenientes da Antártica, que co-habitavam a região estudada com pingüins da espécie Pygoscelis papua. Em relação às sequências nucleotídicas dos fragmentos do gene $M$ dos isolados de maçaricos provenientes da llha de Itamaracá, Pernambuco, ambos possuem 99,2\% de identidade com os isolados de pingüins da Antártica, enquanto que apenas $98,3 \%$ de identidade com a cepa de referência do grupo I (Ulster). Estes indícios apontam que a infecção de pingüins por outras espécies aviárias, poderia ocorrer mesmo fora da Antártica e nesse caso, ao retornarem, seriam potenciais disseminadores e mantenedores do NDV na Antártica. 


\section{CONCLUSÃO}

- A técnica de Real-Time PCR (qPCR) se mostrou bastante eficiente e uma ferramenta poderosa em estudos de vigilância epidemiológicos utilizando amostras clínicas de swabs de aves assintomáticas. Sua elevada sensibilidade analítica foi demonstrada com a detecção de amostras padrões vacinais, bem como a detecção de isolados com, deduzida, baixa concentração viral. A especificidade analítica também foi demonstrada em testes com amostras padrões de diferentes patógenos pertencentes à mesma família do vírus estudado (Paramixoviridae). Do mesmo modo foi demonstrada a elevada sensibilidade e específicidade da qPCR para 0 gene $F$, assim como seu uso potencial na patotipificação de novas cepas, uma vez que seus resultados apresentaram perfeita conformidade com os testes biológicos de Tempo Médio de Morte dos Embriões (TME), realizados nas mesmas amostras.

- A detecção de anticorpos anti-NDV em aves silvestres e aves caipiras e o isolamento do NDV em aves nas três regiões estudadas (Norte, Nordeste e Sul) sugerem que o vírus esteja circulando por todo o Brasil e que esteja sendo carreado e/ou mantido por aves selvagens, migratórias ou não, bem como por criações de aves não comerciais, sobretudo as áquaticas. Porém foi constatado por métodos moleculares e biológicos (qPCR, sequênciamento de DNA e TME $>100 \mathrm{~h}$ ) que tratamse de cepas de baixa patogenicidade (lentogênicas), corroborando para a manutenção do status do Brasil, de ser livre da Doença de Newcastle (DNC).

- Do mesmo modo, também foi encontrado anticorpos anti-NDV em boa parte dos pingüins estudados por sorologia (33,3\%), além do isolamento do NDV de baixa patogenicidade em 2 deles, demonstrando que em conformidade com a literatura 0 NDV possa estar circulando por virtualmente todo o planeta, incluindo os lugares mais remotos e isolados como a Antártica. Além disso, as similaridades genéticas encontradas entre os isolados sul-americanos e antarticos, bem como os padrões migratórios dos pingüins, servem de base para inferir que estes possam ser considerados importantes carreadores e disseminadores do NDV na Antártica. 
- Não obstante a emergência de linhagens virulentas de NDV a partir de vírus não patogênicos mantidos em aves silvestres tem sido frequentemente documentada, por isso os resultados ora apresentados destacam a importância de se manter as medidas estritas de biossegurança, bem como a necessidade de criação de um programa de vacinação que incluísse as pequenas criações não comerciais, com o propósito de minimizar os riscos que tais aves proporcionam aos grandes produtores/exportadores de frango.

- Por fim, é fundamental que outros estudos na área de vigilância epidemiológica de NDV sejam realizados continuamente e com maior freqüência, monitorando-se populações aviárias em geral, enfatizando-se a necessidade de se estudar as diferentes linhagens virais isoladas ao redor do mundo e avaliando-se a relação vírus-hospedeiro e sua importância na epidemiologia, para que no caso de um surto da doença, este seja detectado o mais precocemente possível e as medidas de contenção possam ser tomadas a tempo de evitar uma grande epidemia, que iria incidir de forma bastante negativa na economia do país. 


\section{REFERÊNCIAS *}

Alexander DJ, Manvell RJ, Collins MS, Broekman SJ, Westbury HA, Morgan I et al. Characterization of paramyxoviruses isolated from penguins in Antarctica and subAntarctica during 1976-1979. Arch Virol. 1989; 109:135-143.

Alexander DJ, Manvell RJ, Collins MS, Brockman SJ. Evaluation of relationships between avian paramyxoviruses isolated from birds of the family Columbidae. Arch Virol. 1991; 116(1-4):267-76.

Alexander DJ, Campbell G, Manvell RJ, Collins MS, Parsons G, McNulty MS. Characterization of an antigenically unusual virus responsible for two outbreaks of Newcastle disease in the Republic of Ireland in 1990. Vet Rec. 1992; 130:65-68.

Alexander DJ. The epidemiology and control of avian influenza and Newcastle disease. J Comp Pathol. 1995; 112: 105-126.

Alexander DJ. Newcastle disease - The Gordon Memorial Lecture British Poultry Sci. 2001; 42: 5-22.

Alexander DJ, Manvell RJ. Heat inactivation of Newcastle disease virus (strain Herts 33/56) in artificially infected chicken meat homogenate. Avian Pathol. 2004; 3(2):

222-5.

Animal Health Australia (AHA). Animal Health in Australia report 1999. Disponível em: http://www.animalhealthaustralia.com.au/aahc/index.cfm?50366357-BBB0-12582B05-561EA6591CD9 2000 [2008 mai 25].

Associação Brasileira dos Produtores e Exportadores de Frangos. Relatório Anual 2007. Disponível em: http://www.aveworld.com.br/img/File/relatorios/ABEF_2006.pdf [2008 out 25].

Ballagi-Pordány A, Wehmann E, Herczeg J, Belák S, Lominiczi B. Identification and grouping of Newcastle disease vírus strains by restriction site analyses of a region from the F gene. Arch Virol. 1996; 141: 243-261.

Beard CW, Hanson RP. Newcastle disease. In: Hofstad MS, Barnes HJ, Calnek BW, Reid WM, Yoder HW, editors. Diseases of Poultry, $8^{\text {th }}$ ed. Iowa State University Press, Ames, lowa, USA. 1981; 452-470.

\footnotetext{
De acordo com:

International Committee of Medical Journal Editors. Uniform requirements for manuscripts submitted to Biomedical Journal: sample references. Available from: http://www.icmje.org [2007 May 22].
} 
Belucci MSP, Vianna JSM, Portz C. Avaliação sorológica do vírus da Doença de Newcastle em aves silvestres. Rev Bras Cien Vet. 1999; 6: 66-68.

Boere GC, Stroud DA. The flyway concept: what is is and what it isn't. In: Boere GC, Galbraith CA, Stroud DA, editors. Waterbirds around the world. pp. 40-47. The Stationary Office, Edinburgh, UK. 2006. Disponível em: http://www.jncc.gov.uk/PDF/pub07_waterbirds_part1_flywayconcept.pdf [2008 Out 16].

Briggs LC, Ashton RM, Metcalf P. Development of a Highly Sensitive Screen for Influenza $A$ in Guano and Its Application in the Search for Ancient RNA Preserved Under Antarctic Adelie Penguin Colonies. Avian Dis. 2003; 47(3): 1200-1202.

Brown CC, King DJ, Seal BS. Comparison of pathology-based techniques for detection of viscerotropic velogenic Newcastle disease virus in chickens. J Comp Pathol. 1999; 120(4): 383-9.

Buehler DM, Piersma T. Travelling on a budget: predictions and ecological evidence for bottlenecks in the annual cycle of long-distance migrants. Phil Trans R Soc B. 2008; 363: 247-266.

Centro Nacional de Pesquisa para Conservação das Aves Silvestres (CEMAVE IBAMA). Aves Migratórias na Amazônia e a Gripe Aviária. Informe 35/2006.

Center for Infectious Disease Research \& Policy (CIDRAP) OIE: Newcastle disease: Technical disease card database, 2003.

Collins MS, Bashiruddin JB, Alexander DJ. Deduced amino acid sequences at the fusion protein cleavage site of Newcastle disease virus showing variation in antigenicity and pathogenity. Arch Virol. 1993; 128: 363-370.

Collins MS, Franklin S, Strong I, Meulemans G, Alexander DJ. Antigenic and phylogenetic studies on a variant Newcastle disease virus using anti-fusion protein monoclonal antibodies and partial sequencing of the fusion protein gene. Avian Pathol. 1998; 27:90-96.

Collins PL, Mclntosh K, Chanock RM. Respiratory syncytial virus. In: Fields BN, editor. Virology. Philadelphia: Lippincott-Raven Publishers; 2001. p. 1313-1351.

Cunha RG, Silva RA. Isolamento e identificação do vírus da Doença de Newcastle no Brasil. Soc Bras Med Vet. 1955; 23: 17-33.

Deibel R, Emord DE, Dukelow W, Hinshaw VS, Wood JM. Influenza viruses and paramyxoviruses in ducks in the Atlantic flyway, 1977-1983, including an H5N2 isolate related to the virulent chicken virus. Avian Dis. 1985; 29: 970-985.

DISEASES OF ANTARCTIC WILDLIFE - report, "Workshop on Diseases of Antarctic Wildlife". Australian Antarctic Division, Channel Highway, Kingston, 7050, Australia; 1998. 
Doyle TM. A hitherto unrecorded disease of fowls due to a filter-passing virus. J Comp Pathol Therap. 1927; 40: 144-169.

Folha de São Paulo 13/01/2002. Disponível em: http://www1.folha.uol.com.br/folha/ciencia/ult306u5767.shtml [2009 jan 20].

Franzo VS. Ocorrência da Doença de Newcastle no Brasil e no mundo; 2007. Disponível em: http://www.unianhanguera.edu.br/anhanguera/ [2008 jan 14].

Gardner H, Brouwer S, Gleeson L, Kerry K, Riddle M. Poultry virus infection in Antarctic penguins. Nature. 1997; 387: 245.

Gould AR, Kattenbelt JA, Selleck P, Hansson E, Della-Porta A, Westbury HA. Virulent Newcastle disease in Australia: molecular epidemiological analysis of viruses isolated prior to and during the outbreaks of 1998-2000. Virus Res. $2001 ; 77: 51-60$.

Gotoh B, Ohnishi Y, Inocencio NM, Esaki E, Nakayama K, Barr PJ et al. Mammalian subtilisin-related proteinases in cleavage activation of the paramyxovirus fusion glycoprotein: superiority of furin/PACE to PC2 or PC1/PC3. J Virol. 1992; 66: 63916397.

Gustafson DP, Moses HE. The English sparrow as a natural carrier of Newcastle disease virus. Am J Vet Res. 1953; 701: 581-85.

Harrington BA, Antas PTZ, Silva F. Northward Shorebird Migration on the Atlantic Coast of southern Brazil. Vida Silv Neot. 1986; 1 (1): 45-54.

Hastenreiter H. La maladie de Newcastle au Brésil. Bull Off Int Epizzot. 1976; 85: 813-817.

Herczeg J, Wehmann E, Bragg RR, Travassos-Dias TM, Hadjiev G, Werner O et al. Two novel genetic groups (VIIb and VIII) responsible for recent Newcastle disease outbreaks in southern Africa, one (VIIb) of which reached southern Europe. Arch Virol. 1999; 144:2087-2099.

ICTVdB - The Universal Virus Database, version 4. Disponível em: http://www.ncbi.nlm.nih.gov/ICTVdb/ICTVdB/ [2008 Out 25].

Ito NMK, Prestes AA, Niciporciukas MC. Newcastle disease virus: some biological characteristics of twelve samples isolated in Brazil. Rev Fac Med Vet Zootec Univ São Paulo. 1986; 23(1): 47-53.

Jestin V, Jestin A. Detection of Newcastle Disease virus RNA in infected allantoic fluids by in vitro enzymatic amplification (PCR). Arch Virol. 1991; 118:151-161.

Jones J. Provisional profile for Newcastle Disease. Veterinary Surveillance Strategy. Department for Environment Food and Rural Affairs. 1-29, 2006 [serial on the internet]. Disponivel em: http://www.defra.gov.uk/animalh/diseases/ vetsurveillance/ profiles/nd-fullprofile.pdf [2007 Ago 15]. 
Kingston DJ, Dharsana R. Mortality in crabs in the presence of Newcastle disease virus. Vet Rec. 1977; 100:433-444.

Kingston DJ, Dharsana R. Newcastle disease virus infection in Indonesian ducks. Philippines J Vet Med. 1979; 18: 125-130.

Kraneveld FC. A poultry disease in the Dutch East Indies. Nederlands Indisch Bladen voor Diergeneeskunde. 1926; 38: 448-450.

Krauss H, Paulick C, Huchzermeyer F, Gylstorff I. Newcastle Disease in a king penguin. Dtsch Tierarztl Wochenschr. 1963; 70: 307-309.

Kubista M, Andrade JM, Bengtsson M, Forootan A, Jonák J, Lind K et al. Review: The real-time polymerase chain reaction. Mol Aspec Med. 2006; 27: 95-125.

Lamb RA, Kolakofsky D. Paramyxoviridae: The viruses and Their Replication. Fields Virology $3^{\text {rd }}$ ed. Philadelphia: Lippincott Williams, Wilkins; 1996. p. 1177-1203.

Lamb RA e Parks GD. Paramyxoviridae: The viruses and Their Replication. Fields Virology $5^{\text {th }}$ Ed. Lippincott Williams, Wilkins, Philadelphia, 2007; p. 1450-1495.

Liu H, Wang Z, Song C, Wang Y, Yu B, Zheng D et al. Characterization of PigeonOrigin Newcastle DiseaseVirus Isolated in China. Avian Dis. 2006; 50:636-640.

Liu H, Wang Z, Wu Y, Wu Y, Sun C, Zheng D et al. Molecular characterization and phylogenetic analysis of new Newcastle disease virus isolates from the mainland of China. Res Vet Sci. 2008; 85: 612-616.

Lomniczi B, Wehmann E, Herczeg J, Ballagi-Pordany A, Kaleta EF, Werner O et al. Newcastle disease outbreaks in recent years in western Europe were caused by an old (VI) and a novel genotype (VII). Arch Virol. 1998; 143:49-64.

Manchang TK, Abdu PA, Saidu L. Epidemiology and Clinicopathologic Manifestations of Newcastle Disease in Nigerian Local Chickens. Rev Élev Méd Vét Pays Trop. 2004; 57 (1-2): 35-39.

Millar NS, Chambers P, Emmerson PT. Nucleotide sequence of the fusion and haemagglutination neuraminidase glycoprotein genes of Newcastle disease virus, strain Ulster: molecular basis of variations of pathogenicity between strains. J Gen Virol. 1988; 69:613-620.

Ministério da Agricultura, Pecuária e Abastecimento (MAPA). Departamento de saúde animal. Plano de contingência para influenza aviária e Doença de Newcastle. 1-30. 2006. Disponível em: http://www.agricultura.gov.br/ $\mathrm{pls} /$ portal/docs/PAGE/MAPA/PROGRAMAS/ AREA ANIANI/PNSA/ PLANO \%20DE\%20 CONTINGENCIA\%20VERS\%C3O\%201.2-\%20ABRIL-2007.PDF/ [2007 ago 15]. 
Ministério da Agricultura, Pecuária e Abastecimento (MAPA). Secretaria de Relações Internacionais do Agronegócio. Balança Comercial do Agronegócio. 2007. Disponível em: www.agricultura.gov.br/agrostat/ [2008 fev 7].

Morgan IR, Westbury HA. Virological studies of Adelie Penguins (Pygoscelis adeliae) in Antarctica. Avian Dis. 1981; 25(4): 1019-26.

Morgan IR, Westbury HA. Studies of viruses in penguins in the Vestfold Hills. Hydrobiologia. 1988; 165: 263-269.

Nagai Y, Klenk HD. Activation of precursors to both glycoproteins of Newcastle disease virus by proteolytic cleavage. Virology. 1977; 77:125-134.

National Veterinay Diagnostic Laboratories (NVSL), USDA. Ames, lowa, USA: United States Department of Agriculture; 2005.

Nelson DL, Cox MM. Structure and Catalysis. Aminoacis, pepitides and proteins. Lehninger Principles of Biochemistry. 4th ed. New York: W. H. Freeman and Company; 2005; p. 75-115.

Office International des Epizooties. OIE alert BRA 2001. Disponível em: http://www.defra.gov.uk/ [2008 Nov 12].

Office International des Epizooties. Manual of Diagnostic Tests and Vaccines for Terrestrial Animals. $5^{\text {th }}$ ed. OIE, Paris. chapter 2.1.15; 2004. Disponível em: http://www.oie.int/eng/normes/MMANUAL/A_00038.htm/[2007 Ago 15].

Office International des Epizooties. Terrestrial Animal Health Code. Article 1.1.2.3., Paris: OIE; 2005.

Office International des Epizooties. Newcastle disease in Brazil.OIE alert message 060706BRA received by e-mail on 6 July 2006. Disponível em http://www.defra.gov.uk/animalh/diseases/monitoring/pdf/nd-brazil070706.pdf/ [2008 Nov 12].

Ogasawara T, Gotoh B, Suzuki H, Asaka J, Shimokata K, Rott R et al. Expression of factor $X$ and its significance for the determination of paramyxovirus tropism in the chick embryo. Embo J. 1992; 11:467-472.

Oliveira BL, Freire FGG, Campos EJ, Lamas JMS. Doenças de aves diagnosticadas em dois laboratórios de Belo Horizonte, entre 1975 e 1980. In: Congresso brasileiro de avicultura; Belo Horizonte; 1981; Anais... Belo Horizonte: UBA; 1981. v. 2; p. 248259.

Oliveira Junior JG, Portz C, Loureiro BO, Schiavo PA, Fedullo LPL, Mazur C et al. Serology for the Newcastle disease virus in non vaccinated birds in the State of Rio de Janeiro, Brazil. Ciênc Rural. 2003; 33: 381-383. 
Oliveira Júnior JG, Schiavo PA, Doretto Júnior L, Orsi MA, Mazur C, Andrade CM. Isolation and biological characterization of JAP99 Newcastle disease virus isolated from domestic ducks (Neta sp) in Rio de Janeiro State. Cienc Rural. 2005; 35(4).

Oliveira RL, Girão FGF. Prevalência da Doença de Newcastle, Brasil, 1971-1979. In: 6th Congresso Brasileiro de Avicultura; 1979; Belo Horizonte. Anais... Belo Horizonte: CBA; 2006. p. 122-28.

Pierson GP, Pfow CJ. Newcastle Disease Surveillance in the United States. J Am Vet Med Assoc. 1975; 801-803.

Poon LL, Chan KH, Wong OK, Yam WC, Yuen KY, Guan Y et al. Early diagnosis of SARS coronavirus infection by real time RT-PCR. J Clin Virol. 2003; 28(3):233-8.

Sakaguchi T, Toyoda T, Gotoh B, Inocencio NM, Kuma K, Miyata T et al. Newcastle disease vírus evolution. I. Multiple lineages defined by sequence variability of the hemaglutinin-neuraminidase gene. Virology. 1989; 169: 260-270.

Sakai K, Yada K, Sakabe G, Tani O, Miyaji K, Nakamura M et al. Serological and Virological Studies of Newcastle Disease and Avian Influenza in Slaughter-Age Ostriches (Struthio camelus) in Japan. J Vet Med Sci. 2006; 68(5): 491-494.

Sales TS, Hervai EFG, César AER, Ramos I, Batinga TB, Silva OS et al. Títulos de anticorpos contra o vírus da Doença de Newcastle em três diferentes sistemas de criação avícola na região de Feira de Santana - Bahia. Rev Bras Saúde Prod An. 2007; 8(4): 386-393.

Santos JA. A ocorrência da Doença de Newcastle no Brasil (nota prévia). Rev Prod Anim. 1954; 1: p.5-12.

Scientific Committee on Antarctic Research (SCAR). Disponível em: http://www.scar.org/treaty/ [2008 Dec 20].

Seal B, King DJ, Bennett J. Characterization of Newcastle disease virus isolates by reverse transcription PCR coupled to direct nucleotide sequencing and development of sequence database for pathotype prediction and molecular epidemiological analysis. J Clin Microbiol. 1995; 33: 2624-2630.

Seal BS. Analyses of matrix protein gene nucleotide sequence diversity among Newcastle disease vírus isolates demonstrates that recent disease outbreaks are caused by viruses of psittacine origin. Vir Gen. 1996; 11:217-224.

Sick H. Ornitologia Brasileira. Rio de Janeiro: Ed. Nova Fronteira; 1997.

Sick H. Migrações de aves na América do Sul Continental. Brasília: IBDF; 1983. 86p.

Silva RA. Novos focos da Doença de Newcastle no Brasil. Arq Inst Bio Anim. 1961; 4: 109-14. 
Silva JSA, Mota RA, Vilela SMO, Doretto JL, Pinheiro JJW, Silva LBG. Newcastle Disease Virus Infection in Sparrows (Passer domesticus, Linneaus, 1758) Captured in Poultry Farms of the Agreste Region of the State of Pernambuco. Braz J Poultry Sci. 2006; 8: 125 -129.

Secretaria de Vigilância em Saúde (SVS). Inquérito sorológico em aves migratórias e residentes de Galinhos/RN para detecção do vírus da febre do Nilo Ocidental e outros vírus. Boletim eletrônico epidemiológico. 2004;4(2).

Tauil PL. Urbanização e ecologia. Cad Saúde Pública. 2001; 17(suppl.): p.99-102.

Toyoda T, Sakaguchi T, Hirota H, Gotoh B, Kuma K, Miyata T et al. Newcastle disease evolution. II. Lack of gene recombination in generating virulent and avirulent strains. Virology. 1989; 169: 273-282.

Ujvári D, Wehmann E, Kaleta EF, Werner O, Savic V, Nagy E et al. Phylogenetic analysis reveals extensive evolution of avianparamyxovirus type 1 strains of pigeons (Columba livia) and suggestsmultiple species transmission. Virus Res. 2003; 96: 6373.

Vaitsman J, Moussatcé I. Doença de Newcastle. Boletim 801 do Serviço de Informação Agrícola, Ministério da Agricultura. Brasília: Ministério da Agricultura; 1954. $56 \mathrm{p}$.

Venturini KS, Sarcinelli MF, da Silva LC. Características da Carne de Frango. Boletim Técnico - PIE-UFES:01307. Universidade Federal do Espírito Santo - UFES. Pró-Reitoria de Extensão - Programa Institucional de Extensão. 2007. Disponível em: http://www.agais.com/telomc/b01307_caracteristicas_carnefrango.pdf/ [2008 dec 15].

Wallensten A, Munster VJ, Karlsson M, Lundkvist A, Brytting M, Stervander M et al. High prevalence of influenza $A$ virus in ducks caught during spring migration through Sweden. Vaccine. 2006; 24(44-46): 6734-5.

Wehmann E, Ujvári D, Mazija H, Velhner M, Ciglar-Grozdanic I, Savic' V. Genetic analysis of Newcastle disease virus strains isolated in Bosnia-Herzegovina, Croatia, Slovenia and Yugoslavia reveals the presence of only a single genotype, $\mathrm{V}$, between 1979 and 2002. Vet Microbiol. 2003; 94: 269-281.

Westbury H. Commentary, Newcastle disease virus: an evolving pathogen. Avian Pathol. 2001; 30: $5-11$.

Wise MG, Suarez DL, Seal BS, Pedersen JC, Senne DA, King DJ et al. Development of a Real-Time Reverse-Transcription PCR for Detection of Newcastle Disease Virus RNA in Clinical Samples. J Clin Microbiol. 2004; 42(1): 329-338.

Wobeser G, Leighton FA, Norman R, Myers DJ, Onderka D, Pybus MJ et al. Newcastle disease in wild water birds in western Canada, 1990. Can Vet J. 1993; 34: 353-359. 
Yang C, Chang YPC, Hwang JM, Sheih HK. Nucleotide sequence and phylogenetic analysis of Newcastle disease virus isolates from recent outbreaks in Taiwan. Avian Dis. 1997; 41: 365-373.

Zanetti F, Berinstein A, Pereda A, Taboga O, Carrilo E. Molecular characterization and phylogenetic analysis of Newcastle disease vírus isolates from healthy wild birds. Avian Dis. 2005; 49: 546-550. 